\section{GEOSPHERE}

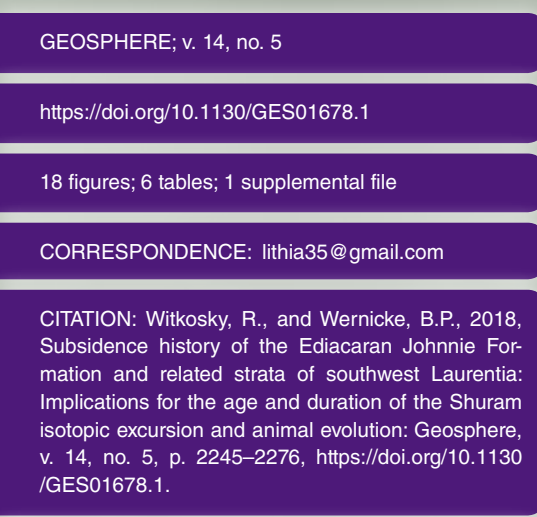

Science Editor: Raymond M. Russo

Associate Editor: Christopher J. Spencer

Received 10 February 2018

Revision received 30 A

Accepted 19 July 2018
Published online 14 August 2018

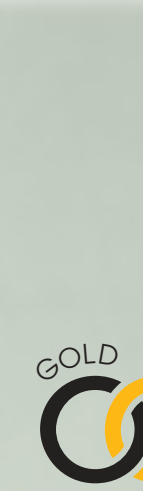

OPEN ACCESS

THE GEOLOGICAL SOCIETY OF AMERICA ${ }^{\circledR}$

\title{
Subsidence history of the Ediacaran Johnnie Formation and related strata of southwest Laurentia: Implications for the age and duration of the Shuram isotopic excursion and animal evolution
}

Rebecca Witkosky and Brian P. Wernicke

Division of Geological and Planetary Sciences, California Institute of Technology, 1200 E. California Boulevard, MC 170-25, Pasadena, California 91125, USA

\section{ABSTRACT}

The Johnnie Formation and associated Ediacaran strata in southwest Laurentia are $\sim 3000 \mathrm{~m}$ thick, with a Marinoan cap carbonate sequence at the bottom, and a transition from Ediacaran to Cambrian fauna at the top. About halfway through the sequence, the Shuram negative carbon isotopic excursion occurs within the Rainstorm Member near the top of the Johnnie Formation, followed by a remarkable valley incision event. At its type locality in the northwest Spring Mountains, Nevada, the Johnnie lithostratigraphy consists of three distinctive sand-rich intervals alternating with four siltstone/carbonate-rich intervals, which appear correlative with other regional Johnnie Formation outcrops. Carbon isotope ratios in the sub-Rainstorm Member part of the Johnnie Formation are uniformly positive for at least $400 \mathrm{~m}$ below the Shuram excursion and compare well with sub-Shuram excursion profiles from the Khufai Formation in Oman. There is historical consensus that the Johnnie and overlying formations were deposited on a thermally subsiding passive margin. Following previous authors, we used Paleozoic horizons of known biostratigraphic age to define a time-dependent exponential subsidence model, and extrapolated the model back in time to estimate the ages of the Shuram excursion and other prominent Ediacaran horizons. The model suggests that the Shuram excursion occurred from 585 to $579 \mathrm{Ma}$, and that incision of the Rainstorm Member shelf occurred during the $579 \mathrm{Ma}$ Gaskiers glaciation. It further suggests that the base of the Johnnie Formation is ca. $630 \mathrm{Ma}$, consistent with the underlying Noonday Formation representing a Marinoan cap carbonate sequence. Our results contrast with suggestions by previous workers that the Shuram excursion followed the Gaskiers event by some 20-30 m.y. We suggest instead that the Shuram and Gaskiers events were contemporaneous with the biostratigraphic transition from acanthomorphic to leiospherid acritarchs, and with the first appearance of widespread macroscopic animal life, $38 \mathrm{~m}$.y. prior to the Ediacaran-Cambrian boundary.

\section{INTRODUCTION}

Ediacaran strata record a critical period in Earth history (635-541 Ma), during which metazoan life first appeared (Knoll et al., 2004, 2006; Narbonne et al., 2012). They also record a significant rise in atmospheric and oceanic oxy- gen (Fike et al., 2006; Canfield et al., 2007; McFadden et al., 2008; Sahoo et al., 2012), which was a prerequisite to metabolic function in animals (Knoll and Carroll, 1999; Och and Shields-Zhou, 2012). Neoproterozoic oxygenation resulted in atmospheric oxygen levels generally interpreted as similar to those of the present day (Holland, 2006; Kump, 2008). Today, atmospheric oxygen levels are maintained by photosynthesis from land plants and marine organisms in roughly equal proportions (e.g., Field et al., 1998). It has therefore long been enigmatic that land plants are not preserved in rocks older than ca. $400 \mathrm{Ma}$, or 150 m.y. later than the first appearance of animals. For that reason, it is widely presumed that the rise of animal life required sufficient oxygen production, from either marine photosynthesis, or perhaps some sort of "bootstrap" mechanism from animals themselves, to survive (e.g., Butterfield, 2009; Lenton et al., 2014). In any event, progress toward understanding the fundamental question, "what is the origin of animals?," hinges in part on understanding how and when oxygen became sufficiently available to make animal metabolism possible (e.g., Nursall, 1959).

Among the most fruitful avenues of research along these lines to date has been exploration of proxies for the chemistry of seawater in which animal life first appeared, primarily the stable isotope geochemistry of shallow-marine carbonate strata. The best-preserved Ediacaran strata around the globe that contain carbonate all feature a singularly large (by about a factor of two) negative anomaly in the isotopic composition of carbon, which has been attributed primarily to the isotopic composition of ancient seawater itself (Fike et al., 2006; McFadden et al., 2008; but for an alternative view, see Swart and Kennedy, 2012). The anomaly is best preserved and documented in the Ediacaran Shuram Formation in Oman (Burns and Matter, 1993; Le Guerroué et al., 2006a, 2006b; Osburn et al., 2015), and it is generally referred to as the "Shuram excursion," taking its name from the discovery formation. A similar excursion has been documented in Neoproterozoic sections on five of Earth's seven modern continents, and it occurs only once in each section: Africa (Kaufman et al., 1991; Halverson et al., 2005), Asia (Burns and Matter, 1993; Condon et al. 2005; Melezhik et al., 2005; Fike et al., 2006; McFadden et al., 2008; Macdonald et al., 2009; Osburn et al., 2015), Australia (Calver, 2000; Husson et al., 2015), Europe (Melezhik et al., 2005; Prave et al., 2009), and North America (Myrow and Kaufman, 1999; Corsetti et al., 2000; Corsetti and Kaufman, 2003; Kaufman et al., 2007; Bergmann et al., 2011; Petterson et al., 2011; Verdel et al., 2011; 
Macdonald et al., 2013). The Shuram excursion is the largest known Neoproterozoic or younger carbon isotope anomaly (Grotzinger et al., 2011), and its magnitude is among the largest recorded in Earth history (see, for example, the Paleoproterozoic Lomagundi-Jatuli excursion; Bekker and Holland, 2012).

Global chemostratigraphic expression of the Shuram excursion is a remarkable discovery from at least three perspectives. First, it represents a presumably isochronous fingerprint of a specific interval of time from sections with notoriously sparse age constraints. Second, it implies that a geologically extreme event of uncertain origin occurred at the same time as the rise of animals. Last, the singular magnitude of the excursion contributes to the goal of creating a global composite time series of secular variations in marine carbon isotope ratios. In regard to the third point, the duration of the anomaly raises the potential for using the shapes of the curves, rather than simply the magnitudes of the excursions, as a correlation tool from section to section; this of course presumes a relatively constant sedimentation rate at the hundred-meter scale (Halverson et al., 2005; Saltzman and Thomas, 2012). For the Shuram excursion, $\delta^{13} \mathrm{C}$ values rapidly descend with stratigraphic position to $<-11 \%$, followed by a recovery that is at first gradual and then moderate in slope, with the change occurring near $-4 \%$ o fig. 2 in Condon et al., 2005; fig. 3 in Prave et al., 2009; fig. 16 in Verdel et al., 2011; fig. 3 in Grotzinger et al., 2011; fig. 13 in Macdonald et al., 2013; fig. 1A in Husson et al., 2015).

At present, the most significant impediment to understanding Ediacaran biostratigraphy is the lack of internal age control in most sections around the globe. The ages of the boundaries of the Ediacaran Period are well defined radiometrically in multiple sections. The base is defined by the lithologically distinctive post-Marinoan cap carbonate sequence, which is associated with a $-6 \% \delta^{13} \mathrm{C}$ excursion in carbonate and is precisely dated at $635 \mathrm{Ma}$ in Namibia and China (Hoffmann et al., 2004; Condon et al., 2005). The top is defined by the first appearance of the trace fossil Treptichnus pedum (541 Ma), which is also associated with a $-6 \% \delta^{13} \mathrm{C}$ excursion in carbonate. Other than the first appearance of large Ediacaran body fossils, which usually occurs rather high in most sections relative to the Ediacaran-Cambrian boundary, the Shuram excursion has emerged as the single most distinctive stratigraphic datum that is globally recognized. However, its precise age is poorly constrained, precluding any attempt to meaningfully subdivide some 94 m.y. of Ediacaran time, and creating first-order uncertainties in the relative timing of major environmental and biostratigraphic events (Xiao et al., 2016). A second major stratigraphic feature, largely restricted to sections in the North Atlantic region, is the Gaskiers glaciation (Myrow and Kaufman, 1999), which, in contrast to the Shuram event, is precisely dated at $579 \mathrm{Ma}$ (Bowring et al., 2003a, 2003b; Pu et al., 2016). The mismatch between sections with glaciogenic rocks and precise radiometric ages on one hand, and the Shuram excursion in carbonate strata on the other, has left it uncertain whether or not these two events are correlative (Xiao et al., 2016). A $580 \mathrm{Ma}$ age for the Shuram excursion provides an obvious correlation between the two most conspicuous events in the Ediacaran record (e.g., Xiao et al., 2004; Fike et al., 2006; Zhou et al., 2007; Halverson et al., 2005, 2010; Loyd et al., 2012; Schiffbauer et al., 2016). Alternatively, the stratigraphic proximity of the Shuram excursion to the Precambrian-Cambrian boundary, and a $551 \mathrm{Ma}$ ash bed near the apparent upper zero crossing of the excursion in the Doushantuo Formation of China, suggest that it may be as much as $20-30$ m.y. younger than the Gaskiers glaciation (Condon et al., 2005; Bowring et al., 2007; Cohen et al., 2009; Sawaki et al., 2010; Narbonne et al., 2012; Macdonald et al., 2013; Tahata et al., 2013; Xiao et al., 2016).

One chronological tool that has heretofore only been sparingly applied to Ediacaran strata is thermal subsidence analysis (e.g., Le Guerroue et al., 2006b). It is well known that thermal subsidence associated with seafloor spreading is a useful chronometer that can predict the age of the ocean floor based on the exponential decay of its elevation with respect to the abyssal plains for lithosphere older than 20 m.y. (e.g., equation 22 in Parsons and Sclater, 1977). The same principle also applies to models of the subsidence history of passive-margin basins, which include an initial thickness of newly stretched continental crust and substantial sediment loading (McKenzie, 1978). The decay is predicted by laws of diffusive heat transport of physical rigor that are on par with laws of closed-system radioactive decay used to date the timing of crystallization of minerals. The principal limitations in using thermal conduction as a chronometer are (1) the requirement that subsidence records thermal relaxation without significant mechanical modification of the lithosphere, such as extension, flexural loading, instability of a thermal boundary layer, or unmodeled sources of dynamic topography; and (2) corrections of the observed stratigraphic subsidence for the compaction and lithification of sediment after deposition, and for water depth and changes in sea level (e.g., Steckler and Watts, 1978; Allen and Allen, 2005).

In comparison with Phanerozoic sedimentary basins, published subsidence analyses of Ediacaran strata have been limited, with most of the effort thus far concentrated on the western Laurentian continental margin (Stewart and Suczek, 1977; Bond et al., 1983; Armin and Mayer, 1983; Levy and ChristieBlick, 1991; Yonkee et al., 2014). The focus on this region as a testing ground for thermal subsidence modeling was due to the fact that it is perhaps the best-preserved example of an ancient passive margin, analogous to present-day Atlantic-type margins, but with virtually complete surface exposure of apparent synrift and postrift sedimentary archives spanning several hundred million years (Stewart, 1972; Gabrielse, 1972; Burchfiel and Davis, 1972, 1975; Stewart and Poole, 1974; Dickinson, 1977; Monger and Price, 1979). Because these sequences span the Ediacaran-Cambrian boundary, such that roughly half their thickness is Proterozoic in age, temporal control on subsidence has been restricted mainly to the Phanerozoic portion of subsidence curves. The lack of age control on the lower part of the section precludes precise definition of the transition from mechanical extension to pure thermal subsidence. Fortunately, the accurate definition of an exponentially decaying system, in particular, extrapolating stratigraphic age backward in time from a curve with known ages, is independent of the timing of onset and total amount of purely thermal subsidence.

Here, we address the problem of the correlation and age of the Shuram isotopic excursion through lithostratigraphic and chemostratigraphic study of 
the type locality of the Ediacaran Johnnie Formation in the Spring Mountains of southern Nevada. The Johnnie Formation is at least $1800 \mathrm{~m}$ thick at the type locality, and it makes up more than half of the maximum known thickness of $\sim 3000 \mathrm{~m}$ of total Ediacaran strata exposed in this region. The underlying Noonday Formation provided the first isotopic match between the Marinoan cap carbonate sequence in Namibia (Hoffman et al., 1998) and a section from another continent (Petterson et al., 2011). The overlying Stirling and Wood Canyon Formations contain Ediacaran and Lower Cambrian fossil assemblages that define the Cambrian-Precambrian boundary within the lower part of the Wood Canyon Formation (Corsetti and Hagadorn, 2000; Hagadorn and Waggoner, 2000), $1200 \mathrm{~m}$ above the top of the Johnnie Formation in the Spring Mountains. The uppermost $300 \mathrm{~m}$ of section of the Johnnie Formation contains the best expression of the Shuram excursion in Laurentia (Corsetti and Kaufman, 2003; Kaufman et al., 2007; Bergmann et al., 2011; Verdel et al., 2011). Therefore, to the extent that the section was deposited at or very near sea level on a thermally subsiding continental shelf, subsidence analysis may be used to estimate the age of the Shuram excursion and perhaps even broadly constrain the overall age of the Johnnie Formation.

\section{GEOLOGIC SETTING}

Neoproterozoic-Cambrian strata in western Laurentia are divisible into two principal components, including a lower diamictite and volcanic sequence, and an upper terrigenous detrital sequence (Stewart and Suczek, 1977; Poole et al., 1992). The Johnnie Formation is the lowest siliciclastic formation in the upper terrigenous detrital sequence, forming the basal deposits of a westward-thickening continental margin terrace wedge, widely regarded to have developed in the wake of late Neoproterozoic rifting of the Rodinian supercontinent ( $\mathrm{Li}$ et al., 2008, 2013). The formation is a few hundred meters thick near its eastern pinchout beneath Lower Cambrian cratonic strata, systematically increasing to at least $1500 \mathrm{~m}$ thick in its westernmost exposures, where the base is not definitively exposed (Stewart, 1970; this report). Lithologically, it is primarily variegated siltstone and very fine-grained sandstone that contains varying amounts $(10 \%-40 \%)$ of carbonate and orthoquartzite, distinguishing it from the carbonate-dominated Noonday Formation below and coarse siliciclastic rocks of the Stirling Formation above (Fig. 1).

The Johnnie Formation was first defined and described in the northwest Spring Mountains in the Johnnie Wash area (Fig. 2; Nolan, 1924, 1929), where its contact with the underlying Noonday Formation is apparently not exposed and hence its thickness is a minimum for this location. Nolan's (1924) thickness and description were included in the regional stratigraphic synthesis of Stewart (1970). The type locality was subsequently mapped and briefly described by Burchfiel (1964, 1965), and relatively complete lithostratigraphic sections were measured by Hamill (1966) and Benmore (1978). The type locality has since received little attention in comparison to the much thinner sections in the Nopah Range and environs $70 \mathrm{~km}$ to the south, or equivalents $100 \mathrm{~km}$ to the west

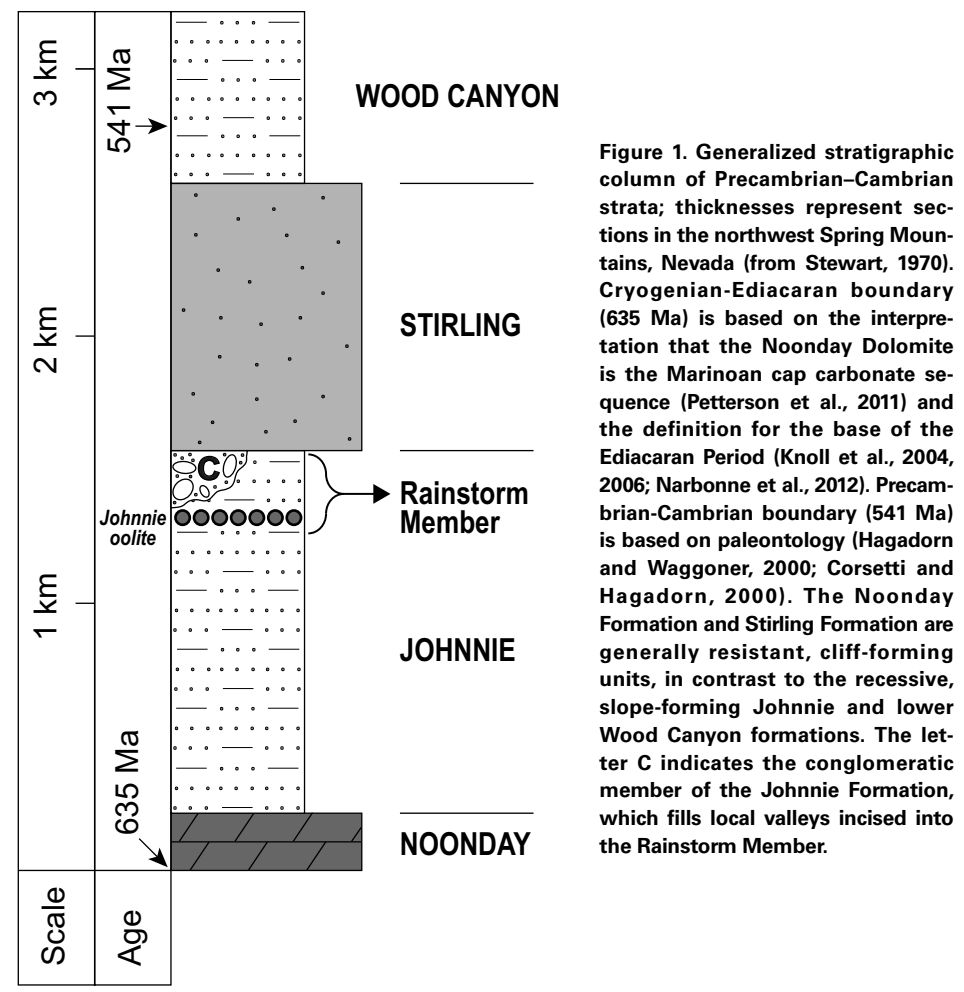

in the Panamint Range, where its basal contact with the Noonday Formation is extensively exposed (e.g., Hazzard, 1937; Wright and Troxel, 1966; Labotka et al., 1980; Albee et al., 1981; Benmore, 1978; Summa, 1993; Fedo and Cooper, 2001; Corsetti and Kaufman, 2003; Kaufman et al., 2007; Verdel et al., 2011). With the exceptions of detailed studies of parts of the formation (Summa, 1993; Abolins, 1999; Bergmann et al., 2011), no systematic attempt has yet been made to describe and interpret the entire formation at its type locality in terms of key bed forms, depositional environments, sequence architecture, or chemostratigraphy, at the level of more southerly or westerly sections.

The uppermost part of the Johnnie Formation, the Rainstorm Member, is a lithostratigraphically distinctive unit that can be correlated with confidence over a broad region of southwestern North America, including eastern California and southern Nevada (Stewart, 1970), and it probably occurs as far south as northern Sonora, Mexico, where it forms a part of the Clemente Formation (Stewart et al., 1984). The basal strata of the Rainstorm Member are its most distinctive part. They include a thin $(\sim 2 \mathrm{~m})$, siltstone-enveloped, regionally extensive oolitic marker bed known as the "Johnnie oolite" (e.g., Bergmann et al., 2011). The oolite is underlain by greenish gray siltstone, and it is over- 
Figure 2. (A) Google Earth image and (B) corresponding geologic map of Precambrian-Cambrian strata in the northwest Spring Mountains, Nevada, in the vicinity of the type locality of the Johnnie Formation in Johnnie Wash. GF-Grapevine fault; JW-Johnnie Wash; MA-Montgomery anticline; NV-160-Nevada State Highway 160; PF-Paddy's fault. Dotted line labeled d/e indicates the conspicuous surface trace of the contact between informal members $D$ and $E$ of the Johnnie Formation. Data were compiled from Abolin 79, 1983), and this study.

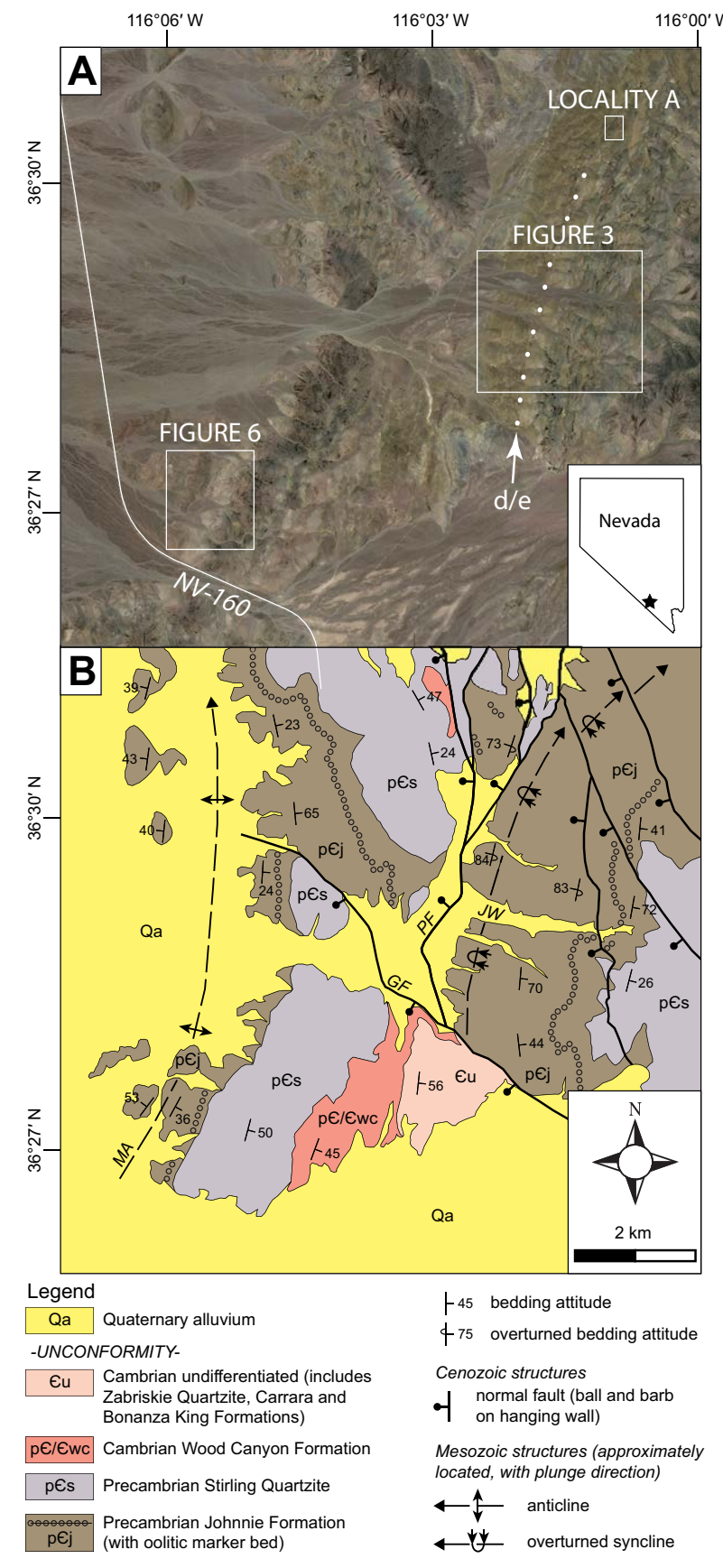

lain by distinctive pale-red, fine-grained sandstone with or without associated sandy or silty micrites ("liver-colored limestones"). The overlying units characteristically contain groove marks, flute casts, intraformational conglomerate, and other indicators of shallow-water, high-energy currents. These carbonates record the onset and most negative part of the Shuram excursion in eastern California and southern Nevada (Corsetti and Kaufman, 2003; Kaufman et al., 2007; Verdel et al., 2011), as well as in the Sonora sections (Loyd et al., 2012). Similar to formation-scale thickness variations in the terrigenous detrital sequence as a whole, the Rainstorm Member generally thickens westward from as little as $20 \mathrm{~m}$ in the thinnest measured section to more than $300 \mathrm{~m}$ in the thickest sections (Stewart, 1970; Verdel et al., 2011).

Lower and middle Johnnie Formation strata are sufficiently variable in their lithostratigraphy that recognition of regionally mappable members is not as straightforward as in the case of the Rainstorm Member. As noted by Summa (1993), sub-Rainstorm Member depositional settings of the Johnnie Formation are interpreted as inner-shelf to tidally influenced nearshore environments that were highly susceptible to sea-level fluctuation (Benmore, 1978; Fedo and Cooper, 2001; Schoenborn et al., 2012). As we describe herein, depositional environments tend to be more landward to the south and east in these units, as suggested by the abundance versus absence of desiccation features, fluvial versus marine deposition, and medium- to coarse-grained sandstones versus fine- to medium-grained sandstones. Although this variability complicates simple lithostratigraphic correlation, if interpreted correctly, it can be used as an effective indicator of sea-level rise and fall.

Reported age constraints from the Johnnie and correlative Clemente formations include (1) a $640 \mathrm{Ma} \mathrm{U}-\mathrm{Pb}$ age from a single detrital zircon grain in sub-Rainstorm Member siltstones in the Panamint Range of eastern California (Verdel et al., 2011), and (2) potential Ediacaran body and trace fossils (e.g., Cyclomedusa plana and Palaeophycus tubularis, respectively) $\sim 75 \mathrm{~m}$ below the oolite in the Clemente Formation (McMenamin, 1996). The U-Pb age, because it is based on a single grain, is subject to the uncertainty of contamination during mineral processing and needs to be confirmed with duplicate analyses. The putative fossils have been questioned after examination by other paleontologists (e.g., J.W. Hagadorn, 2017, personal commun.), and they have generally not been accepted in subsequent stratigraphic studies of the region (e.g., Loyd et al., 2012, 2015). Latest Ediacaran fossils have been recovered from the uppermost Stirling Formation and the Lower Member of the Wood Canyon Formation in the Spring Mountains and neighboring Montgomery Mountains to the south (e.g., Cloudina and Swartpuntia; Hagadorn and Waggoner, 2000; Smith et al., 2017), from sections in stratigraphic continuity with the type Johnnie Formation. These are succeeded immediately upward by Lower Cambrian trace fossils (Treptichnus pedum), which places the Ediacaran-Cambrian boundary in the Lower Member of the Wood Canyon Formation (Fig. 1; Corsetti and Hagadorn, 2000).

The underlying Noonday Formation has been interpreted as the cap carbonate sequence of the Marinoan "snowball Earth" glaciation (Petterson et al., 2011), which by definition would place its base at the beginning of the Edia- 


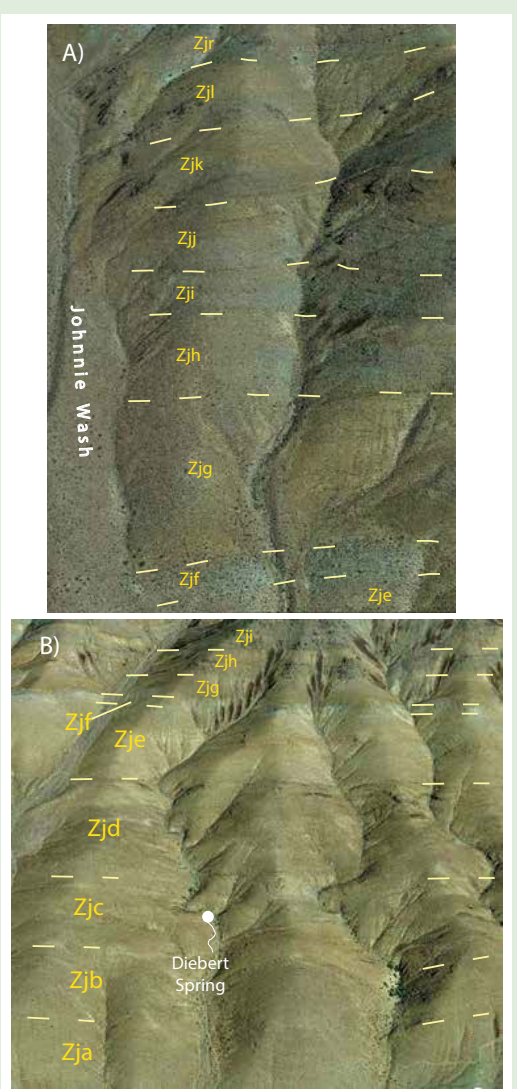

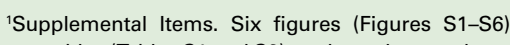
two tables (Tables $\mathrm{S} 1$ and $\mathrm{S} 2$ ), and supplemental text. Please visit https://doi.org/10.1130/GES01678.S1 or access the full-text article on www.gsapubs.org to view the Supplemental Items. caran period (635 Ma; Knoll et al., 2004, 2006; Narbonne et al., 2012). The Johnnie Formation's basal contact with the Noonday Formation is lithostratigraphically gradational, transitioning from sandy dolostones of the upper Noonday Formation (Mahogany Flats Member of Petterson et al., 2011) to interstratified dolomitic sandstone and orthoquartzite in the lower Johnnie Formation (Transitional Member of Stewart, 1970). Although traditionally regarded as a conformable contact on the basis of this gradation (Hazzard, 1937; Stewart, 1970; Wright and Troxel, 1984), the identification of local karstic surfaces along the contact raises the possibility that it is a disconformity with a substantial depositional hiatus (Summa, 1993).

In terms of chemostratigraphic constraints on age, the conspicuous excursions to $-6 \%$ at the base and top of the Ediacaran section are well expressed in the south Laurentian sections (e.g., Petterson et al., 2011; Smith et al., 2016) The presence of the Shuram excursion in the Rainstorm Member, despite its value as a correlation tool, does little to constrain the depositional age, be cause unlike the tightly constrained boundary excursions, hard chronological constraints are lacking, as noted already.

For almost a century, the terrigenous detrital sequence has been studied extensively on many different levels. Much of the early work focused on stratigraphic group-level packages that record the transition from Precambrian to Cambrian time (Nolan, 1929; Burchfiel, 1964; Stewart, 1970). More recent work on the Johnnie Formation has focused largely on outcrops in eastern California (Summa, 1993; Fedo and Cooper, 2001; Verdel et al., 2011; Schoenborn and Fedo, 2011; Schoenborn et al., 2012), or on specific features related to the Rainstorm Member, such as an incision-related conglomeratic member (Summa, 1993; Abolins, 1999; Abolins et al., 2000; Clapham and Corsetti, 2005; Verdel et al., 2011), giant ooids (Trower and Grotzinger, 2010), or detailed chemostratigraphy of the Johnnie oolite (Bergmann et al., 2011). The lower and middle portions of the Johnnie Formation have not been given as much detailed attention, except in areas close to the craton miogeoclinal hinge, where the Johnnie Formation is only a few hundred meters thick. The $1600 \mathrm{~m}$ stratigraphic thickness of sub-Shuram excursion Johnnie Formation at the type locality exceeds the thickness of any globally correlative Ediacaran strata of which we are aware. Furthermore, total Ediacaran stratigraphic thickness in southwest Laurentia measures over $3000 \mathrm{~m}$, greater than the approximate thicknesses of sections in Australia $(2500 \mathrm{~m})$, Oman $(1500 \mathrm{~m})$, and China $(300 \mathrm{~m})$. Strata of the lower and middle Johnnie Formation at its type locality therefore represent one of the best opportunities among sections globally to provide a relatively complete record of Ediacaran time prior to the Shuram excursion. An important gap in our understanding of Ediacaran chemostratigraphy is the paucity of carbonate strata below the Shuram anomaly in most sections. Of the major global sections that contain it, only the Oman example contains abundant carbonate in immediately underlying strata, the Khufai Formation. Discovery of correlative carbonate-bearing strata in one or more sections around the globe would thus represent a significant step in expanding the global inventory of chemostratigraphic time series for a critical interval in Neoproterozoic time.

\section{METHODS}

\section{Lithostratigraphy}

To identify a structurally intact section of the Johnnie Formation, we performed geologic mapping at 1:10,000 scale in the northwest Spring Mountains, Nevada, both of the type locality at Johnnie Wash, and in an area $\sim 4 \mathrm{~km}$ to the southwest near Nevada Highway 160, 3 km west-southwest of Mount Schader (Fig. 2). We used the Mount Schader, Nevada 1:24,000 quadrangle map (U.S. Geological Survey, 1968) as a topographic base. Our field mapping spanned $9 \mathrm{~d}$ total between 21 April 2015 and 2 May 2015. The geologic maps were used to identify optimum transects for measuring stratigraphic section. The Mount Schader section was measured and sampled in detail using a Jacobs staff mounted with a Brunton ${ }^{\circledR}$ compass set to the dip of bedding. For each stratigraphic subunit, we recorded: (1) fresh and weathered color of lithology using a Munsell color chart; (2) grain size; and (3) bedding thickness (supplemental text ${ }^{1}$ ). Section was measured to the resolution of $\sim 0.5 \mathrm{~m}$ (or finer in some instances, if warranted). The Johnnie Wash section was measured using geologic cross sections, and the general lithologic characteristics were recorded in the field during geologic mapping (see Appendix for unit names and descriptions).

\section{Chemostratigraphy}

For carbon and oxygen isotope chemostratigraphy, we collected samples at $0.3-1 \mathrm{~m}$ resolution in carbonate units. Samples from the upper $\sim 400 \mathrm{~m}$ of sub-Rainstorm Member lithostratigraphic units were collected from the Mount Schader section during stratigraphic logging. Samples from two prominent carbonate horizons that occur below the deepest exposed strata of the Mount Schader section were collected in the Johnnie Wash locality of the Spring Mountains, and at a location $\sim 3 \mathrm{~km}$ north of Johnnie Wash (locality A in Fig. 2A). In total, 107 centimeter-scale sample chips were collected for carbon and oxygen isotopic analysis, including 36 from the Johnnie Wash section and locality $A$ and 71 from the Mount Schader section. In the laboratory, sample chips were sliced open using a diamond-bladed wet saw to expose fresh, unweathered surfaces. From the fresh surfaces, a high-speed rotary tool with a diamond-tipped drill bit was used to powder the sample. We carefully extracted $\sim 0.1 \mathrm{mg}$ of analyte from each sample chip, taking care to avoid any visible alteration or veining. Sample powder was loaded into vials, the air was purged and replaced with helium gas, and then digested in phosphoric acid at $72{ }^{\circ} \mathrm{C}$ for at least $1 \mathrm{~h}$ to evolve sufficient $\mathrm{CO}_{2}$ gas for analysis. Carbon and oxygen isotope ratios were measured at Caltech using a Delta V Plus isotope ratio mass spectrometer ("gas bench"). Our values for $\delta^{13} \mathrm{C}$ and $\delta^{18} \mathrm{O}$ are reported relative to the Vienna Peedee belemnite (VPDB) standard in per mil notation. We used Caltech's laboratory working standards, which were calibrated to NBS 18 and NBS 19 and have uncertainties of $\pm 0.1 \%$. Standards were measured once for every nine samples to assess systematic error. 


\section{Subsidence Analysis}

Our tectonic subsidence analysis is based on stratigraphic thicknesses com piled from multiple sources for the northwest Spring Mountains, Nevada. The inner-shelf to fluvial-deltaic facies of virtually all units within the terrigenous detrital sequence in this region suggest shallow-water deposition, removing the need for paleobathymetric correction (Levy and Christie-Blick, 1991). We used thicknesses from this study combined with thicknesses for overlying formations principally based on Stewart (1970) and Burchfiel et al. (1974). Our analysis encompasses known time points ranging from the Ediacaran-Cambrian boundary in the Lower Member of the Wood Canyon Formation (Corsetti and Hagadorn 2000; Hagadorn and Waggoner, 2000; Smith et al., 2016, 2017) at $541 \mathrm{Ma}$, up through the Devonian-Mississippian boundary at the top of the Devils Gate Formation (Burchfiel et al., 1974) at $359 \mathrm{Ma}$ (Ogg et al., 2016). The only previous attempt at a geohistory analysis of the Spring Mountains (Levy and Christie-Blick 1991) was temporally constrained mainly by the Lower-Middle and MiddleUpper Cambrian boundaries, which were then deemed to be $\sim 30$ m.y. older than their currently accepted ages. We followed methods described in Allen and Allen (2005) to delithify and progressively unload (backstrip) the stratigraphic column in order to obtain the tectonic component of subsidence. Delithification parameters for siliciclastic rocks were taken from table 9.1 in Allen and Allen (2005), and parameters for carbonate rocks were taken from Equation 3 in Halley and Schmoker (1983). Tectonic subsidence curves were calculated using Backstrip, an open-source software for decompaction and tectonic subsidence calculations (Cardozo, 2009). Results for our earliest model runs were verified by hand using a spreadsheet program (e.g., Larrieu, 1995).

\section{RESULTS}

\section{Lithostratigraphy}

The most salient feature of the Johnnie Formation in the Johnnie Wash type locality (Fig. 3 ) is that, although very fine-grained sandstone and siltstone are present in all mappable units (distinguishing it from the overlying Stirling and underlying Noonday formations), three intervals are characterized by an abundance of fine- to medium-grained sandstone (identified with Roman numerals I, II, and III on Fig. 4). The sand-rich intervals range from 160 to $430 \mathrm{~m}$ thick, form distinct, resistant ridges within the otherwise recessive Johnnie Formation, and establish a basis for subdividing it into mappable units. Each sand-rich interval exhibits characteristics that readily distinguish it from the other two, in terms of either bed forms (intervals I and II) or parasequence architecture (interval III). Further subdivision of the formation is afforded by a conspicuous, 30-40-m-thick cherty carbonate unit near the middle of the section, and by lithological variation within sand-rich interval III. Our subdivision into map units includes the Rainstorm Member at the top, underlain by 12 informal units designated $A$ through $L$ (Fig. 4; Fig. S1 [footnote 1]). Sand-rich intervals I and II define units $B$ and $D$, and their enveloping sand-poor strata define units $A, C$, and $E$. The cherty carbonate marker and overlying sand-poor strata define units $F$ and $G$. The upper sand-rich interval exhibits rhythmic variations of sandstone, siltstone, and carbonate that are divided into five units, $\mathrm{H}$ through $L$, each of which is defined at the base of a 30-100-m-thick sand-rich subinterval (Figs. 3 and 4; Fig. S1 [footnote 1]).

At the Johnnie Wash type section, bedding strikes approximately northsouth and dips moderately to steeply eastward (Fig. 3). The total thickness of sub-Rainstorm Member strata is $1595 \mathrm{~m}$. The lowest stratigraphic unit (unit A) encountered is a recessive, slope-forming phyllitic siltstone that contains a continuous cleavage at high angle to bedding. The base of unit $B$ is defined by the lowest occurrence of meter-scale orthoquartzite beds, which are abundant in the unit. Unit $B$ is readily distinguished from higher sand-rich intervals by pervasive penecontemporaneous deformation. Nearly every sandstone horizon is affected, principally by ball-and-pillow structure, so much so that individual orthoquartzite beds are difficult to trace along strike for more than a few tens of meters. Individual ball-and-pillow structures are up to meter-scale in size (roughly equal to orthoquartzite bed thickness) and occur where finegrained sandstone and siltstone underlie coarser sandstone. The ball-andpillow structure is manifested in some places as simple load casts with folded lamination (Fig. 5A) and in others as completely detached sand bodies that have slumped downward into the underlying siltstone, surrounded by flame structure developed within the siltstone (Fig. 5B). At the type locality, the occurrence of ball-and-pillow structure in the Johnnie Formation is restricted to unit $B$, but it was also observed along one horizon at the top of the Rainstorm Member in the Mount Schader section (Figs. 6 and 7).

Unit $\mathrm{C}$ marks a return to generally inconspicuous, slope-forming siltstone with a prominent orthoquartzite marker horizon near the middle of the unit The uppermost beds include a brown, resistant, 2-m-thick dolostone bed, which marks the lowest occurrence of carbonate in the type section.

Unit $D$ includes orthoquartzite and less abundant siltstone. The sedimentary characteristic that distinguishes unit $D$ from the other two sand-rich intervals is abundant high-angle cross-stratification, preserved in medium- to thick-bedded orthoquartzite (Fig. 8A). Millimeter- to centimeter-scale laminae or thin beds are preserved in foresets within decimeter- to meter-scale beds that can be followed for tens of meters along strike. Foreset lamination is consistently truncated at high angles, ranging from $20^{\circ}$ to $30^{\circ}$, by overlying beds (Fig. 8B). In stratigraphic coordinates (corrected by tilting to horizontal about the line of strike), poles to foreset lamination are strongly unimodal, dispersed in trend by more than $90^{\circ}$ around a mean vector of $\sim \mathrm{N} 30^{\circ} \mathrm{E} 65^{\circ}$ (Fig. 8B). We measured grain-size variation with stratigraphic height across a sequence of about 10 foreset layers (Figs. 8C and 8D) to test for the presence of reverse grading, which is characteristic of dry grain flows on the lee side of dunes (e.g., Hunter, 1977; Boggs, 2012). The results indicated that the mean grain size of $\sim 200 \mu \mathrm{m}$ varies little through the sample, if anything fining slightly upward. In general, the lamination is not defined by concentrations of detrital heavy minerals. Opaque phases in these quartzites are largely diagenetic and relatively uniformly distributed throughout the rock. 


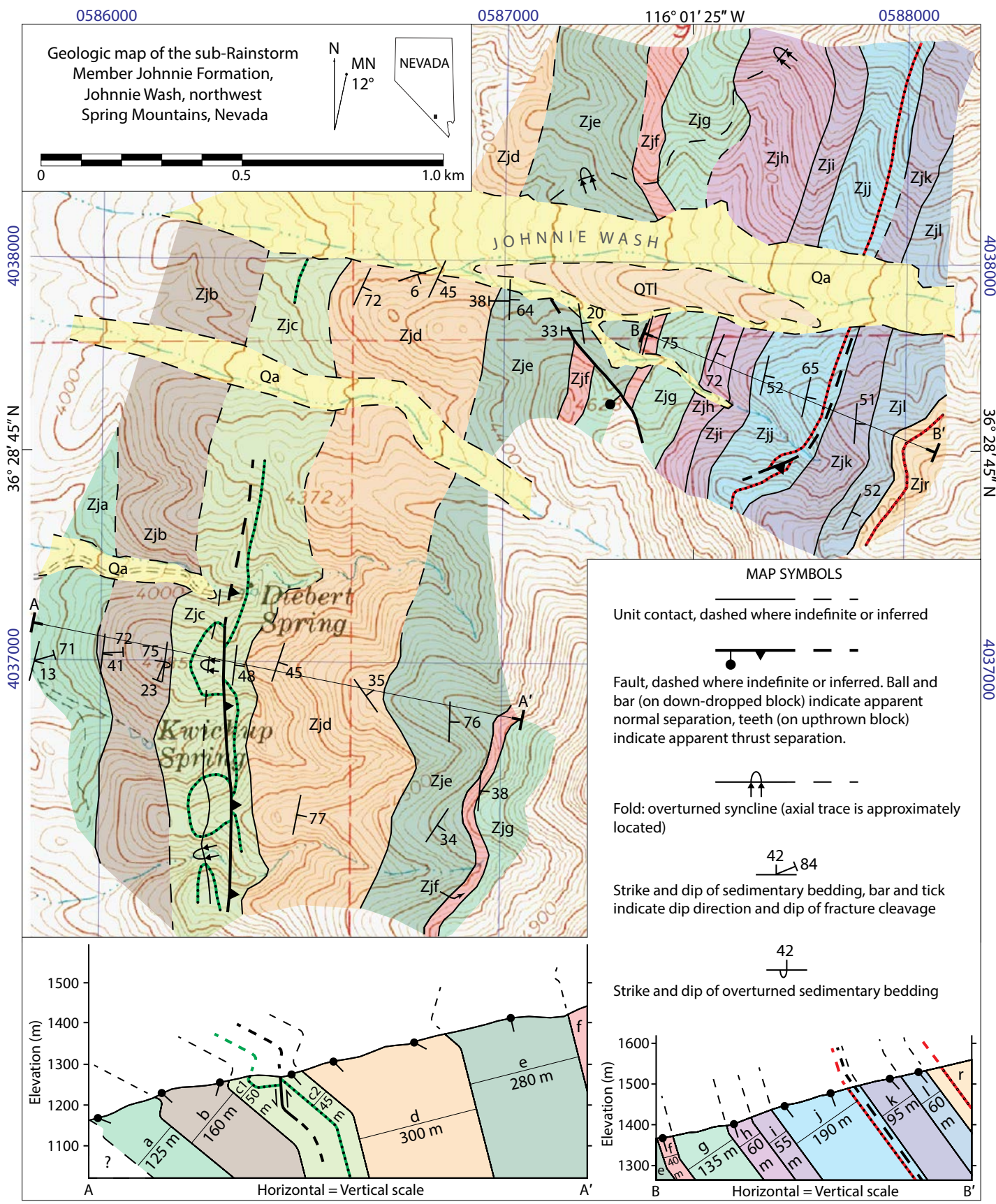

Figure 3. Geologic map and cross sections of Johnnie Wash and environs. Definitions of unit labels and description of map units are given in the Appendix. 
Figure 4. Generalized lithostratigraphic column of the Johnnie Formation at its type locality in Johnnie Wash, with thick nesses based on cross sections $A-A^{\prime}$ and B- $B^{\prime}$ in Figure 3 for units $A$ through $L$, and Stewart (1970) for the Rainstorm Member Roman numerals on left side of column cussed in text.

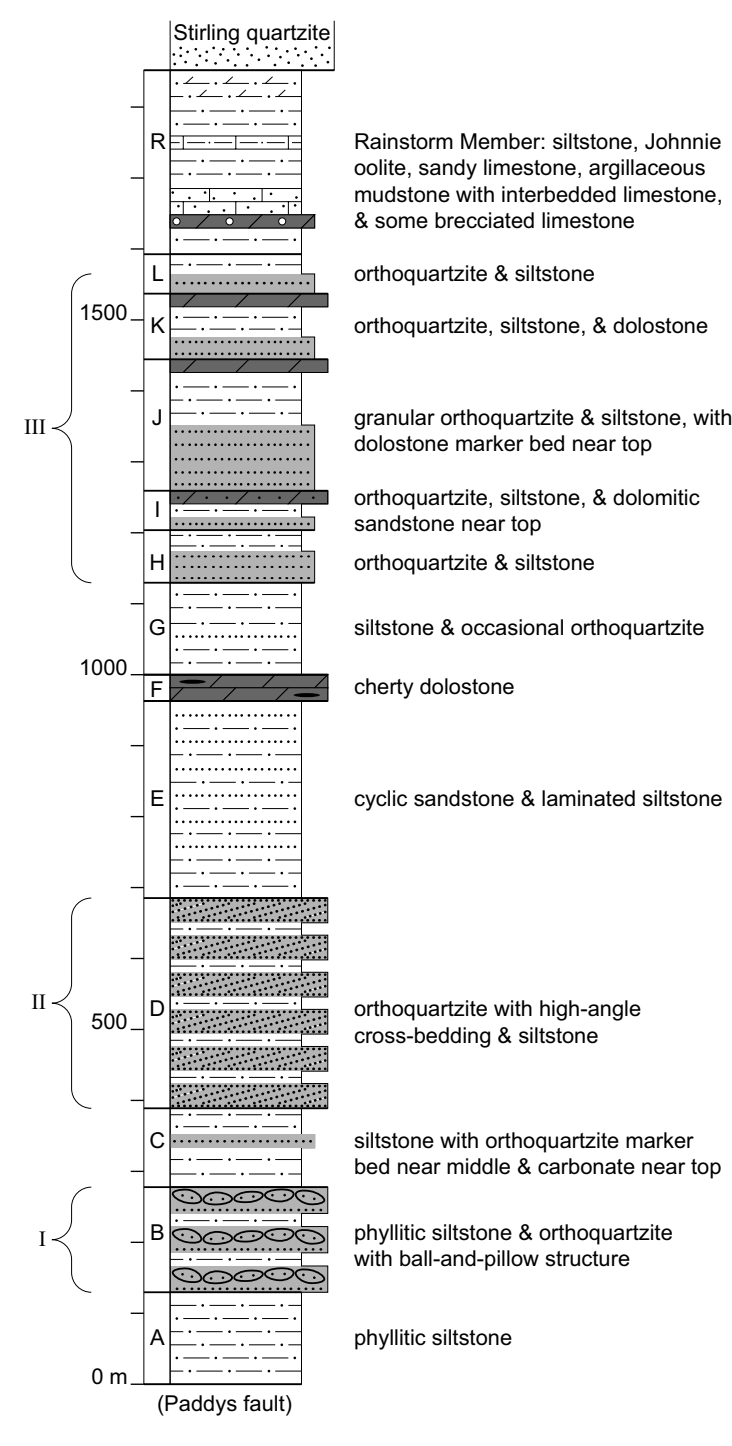

The boundary between units $D$ and $E$ is among the most readily mappable in the area and is also associated with a color change on remote imagery from dark brown to light brown, which is the most conspicuous color contrast in the section (Fig. 2A). Unit $\mathrm{E}$ is $\sim 280 \mathrm{~m}$ thick, and it is dominated by very fine-grained sandstone and siltstone, generally lacking the mature, fine- to medium-grained quartzitic sandstone characteristic of unit D. Near the top, unit $E$ contains an interval of $\sim 30$ medium-bedded cycles that alternate between massive, immature fine-grained sandstone and laminated siltstone. Unit $\mathrm{F}$ is a conspicuous, 30-40-m-thick, gray cherty dolostone (Fig. 5C) that can be followed for at least $5 \mathrm{~km}$ along strike, albeit with some minor faulting. Unit $\mathrm{G}$ is $135 \mathrm{~m}$ thick, and it returns to siltstone and very fine-grained sandstone similar to unit $E$, with a few inconspicuous orthoquartzite beds.

The overall lithostratigraphic character changes beginning at the base of unit $\mathrm{H}$, from relatively thick, homogeneous sandstone-, siltstone-, or carbonatedominated units below to the far more compositionally heterogeneous units above. From the base of unit $\mathrm{H}$ up to the base of the Rainstorm Member, the section contains abundant orthoquartzite, defining the uppermost of the three sand-rich intervals in the Johnnie Formation (Fig. 4). For mapping purposes, the most straightforward subdivision of sand-rich interval III in the Johnnie Wash area is defined by five quartzite-dominated subunits ranging from 10 to $100 \mathrm{~m}$ thick, which define the lower parts of units $\mathrm{H}, \mathrm{I}, \mathrm{J}, \mathrm{K}$, and L (Fig. 4; Fig. S1 [footnote 1]). Each of these subunits is overlain by variable thicknesses of recessive, variegated siltstone (Fig. 5E). The occurrence of carbonate is sporadic. In the section in Johnnie Wash, units I, J, and $\mathrm{K}$ are each capped by a resistant, 1-3-m-thick subunit of brown-weathering, laminated dolostone (Fig. 5D), and units $\mathrm{H}$ and $\mathrm{L}$ do not contain carbonate (Fig. 4). The Mount Schader section contains a lesser proportion of quartzitic sandstone and a greater proportion of carbonate and siltstone (Figs. 6 and 7), which is the basis for selecting it, instead of the type locality, for detailed measurement and chemostratigraphic sampling. Even within the Johnnie Wash area, the distribution of quartzite, siltstone, and carbonate changes along strike, on a scale of a few kilometers (Abolins, 1999). Although orthoquartzite beds in units $\mathrm{H}$ through $\mathrm{L}$ locally exhibit some high-angle cross-stratification in the Johnnie Wash section, they contrast with unit D (sand-rich interval II) in mainly being parallel-bedded or, in the case of the Mount Schader section, hummocky cross-stratified. Orthoquartzite in units $\mathrm{H}-\mathrm{L}$ is generally fineto medium-grained and appears to contrast with lower sand-rich intervals in containing a greater proportion of medium-grained and locally coarsegrained sand.

Our informal unit nomenclature ends at the base of the formally defined Rainstorm Member, which, as noted earlier, is readily identified throughout the region on the basis of lithologic characteristics. In the northern Spring Mountains, the Rainstorm Member contrasts with the underlying units $\mathrm{H}$ through $\mathrm{L}$ in lacking fine- to medium-grained orthoquartzite beds. At the base of the Rainstorm Member, a fissile, phyllitic siltstone is overlain by the ocher-colored, 2-m-thick Johnnie oolite. The ooids are up to $\sim 2 \mathrm{~mm}$ in diameter (Fig. $5 \mathrm{~F}$ ) and exhibit local cross-stratification. The oolite horizon has erosional basal and upper contacts, locally including intraformational breccia and conglomerate, which includes cobbles and small boulders of the oolite. Above the Johnnie oolite, pale-red limestones locally contain dispersed, coarse quartz grains interstratified with carbonate-cemented, fine-grained sandstone. These carbonate-rich rocks are overlain by argillaceous mudstone with interbedded limestones, with scattered horizons of intraformational conglomerate. 


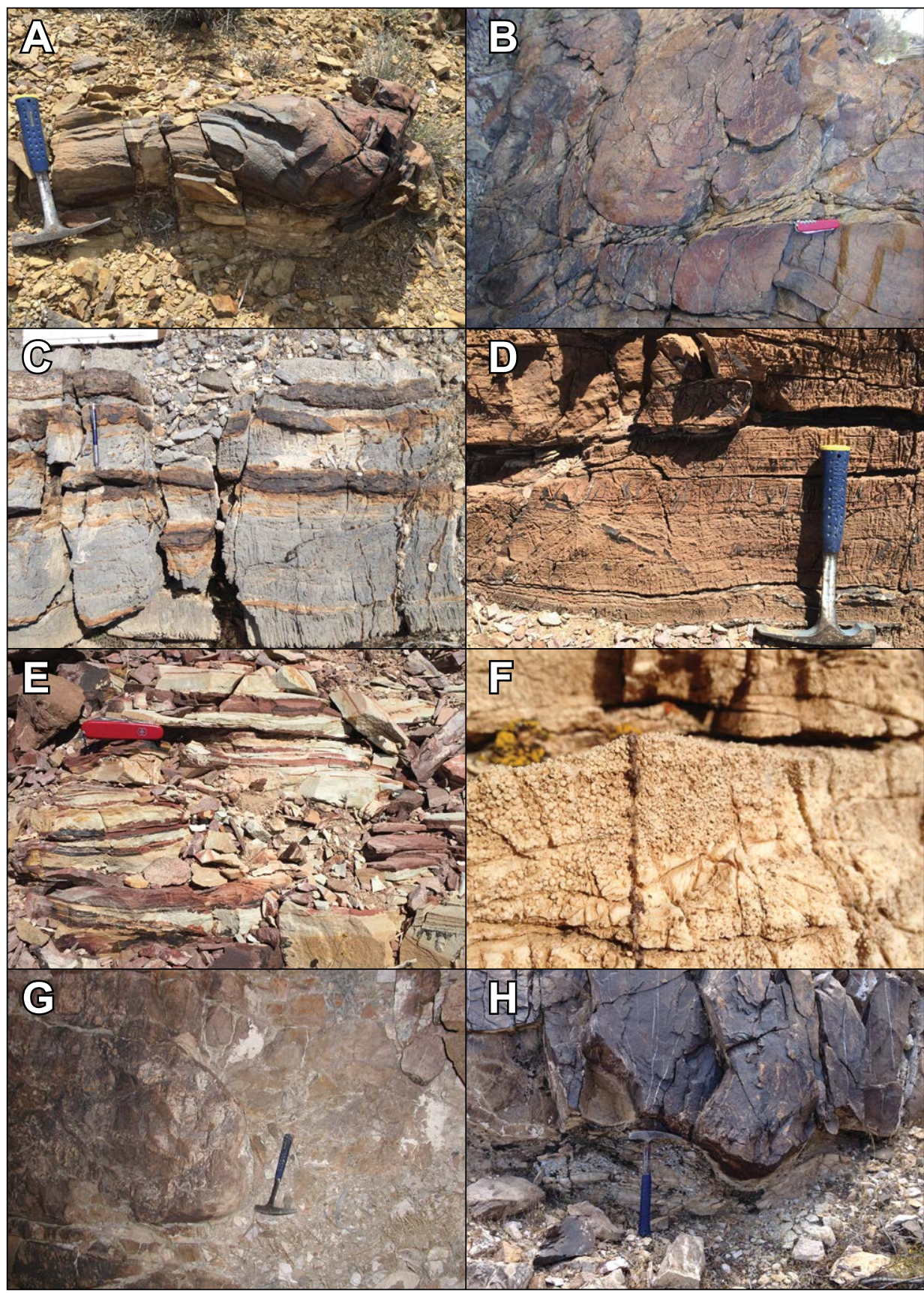

Figure 5. Photographs of selected lithostratigraphic elem mation. (A) Load cast with folded laminae in sandstone bed, unit B, Johnnie Wash area. Hammer is $28 \mathrm{~cm}$ long. (B) Balland-pillow structure in unit $B$, with lightcolored siltstone (just above pocket knife) protruding upward between bulbous masses of fine-grained sandstone. Pocket knife is $9 \mathrm{~cm}$ long. (C) Gray cherty dolostone, unit F, Johnnie Wash. Pencil is $15 \mathrm{~cm}$ long. (D) Brown-weathering, laminated dolostone, typical of carbonate beds in units $\mathrm{H}$ through $\mathrm{L}$. Hammer is $28 \mathrm{~cm}$ long. (E) Variegated siltstone typical of all units in the Johnnie Formation. Pocket knife is $9 \mathrm{~cm}$ long. (F) Johnnie oolite, Johnnie Wash, ooids are $1-2 \mathrm{~mm}$ in diameter. (G) Large, bulbous mass of orthoquartzite (left of hammer), surrounded by smalle masses lying in a matrix of siltstone uppermost bed of the Rainstorm Member Mount Schader section. Hammer is $33 \mathrm{~cm}$ long. (H) Base of orthoquartzite bed in $G_{\text {, }}$ showing load cast structures with under lying siltstone. Hammer is $\mathbf{3 3} \mathbf{~ c m}$ long. 


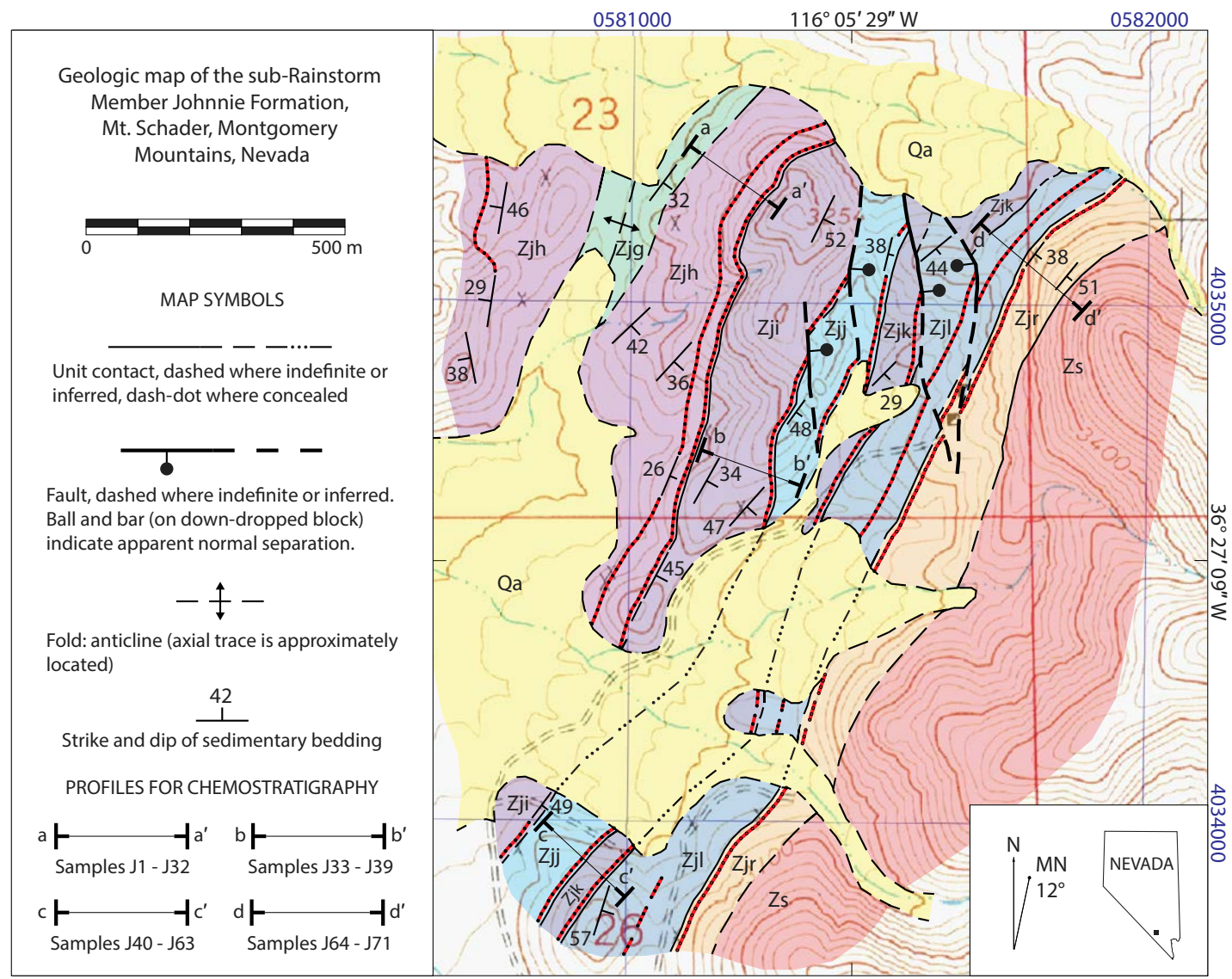

Figure 6. Geologic map of the Mount Schader section, showing measured and sampled transects. Definitions of unit labels and description of map units are given in the Appendix.

The uppermost part of the Rainstorm Member in the Mount Schader section contains a 4-m-thick triad of quartzite, siltstone, and dolostone, in which the quartzite is disrupted by locally intense ball-and-pillow structure (Figs. $5 \mathrm{G}$ and $5 \mathrm{H})$. The base of the overlying A Member of the Stirling Formation is marked by highly resistant, massively textured to cross-stratified, medium- to thick-bedded, medium- to coarse-grained orthoquartzite. The principal contrast between the Stirling Formation's A Member and any of the orthoquartzites in the Johnnie Formation is the coarse grain size, including the common occurrence of granules and small pebbles of vein quartz and jasper. Neither the Johnnie Wash section nor the Mount Schader section appears to preserve the incised valley fill characteristic of the conglomeratic member of the Johnnie Formation (Abolins, 1999; Verdel et al., 2011).

\section{Chemostratigraphy}

Carbon isotope ratios range from a low of $-4.4 \%$ (VPDB) to a high of $4.9 \%$ (Table S1 [footnote 1]). The data are mainly concentrated in carbonate beds in units $\mathrm{H}$ through $\mathrm{L}$, which constitute the uppermost $400 \mathrm{~m}$ of pre-Rainstorm Member strata (Fig. 7). Within the underlying $~ 1100 \mathrm{~m}$ of exposed Johnnie Formation strata, carbonate intervals are present only in units $C$ and $F, 1440 \mathrm{~m}$ and $860 \mathrm{~m}$ below the base of the Rainstorm Member, respectively (Figs. 4 and 9). The lowest and highest values of $\delta^{13} \mathrm{C}$ occur in the stratigraphically highest samples, and they define a strong negative trend, beginning near the top of unit $K$ and ending at the top of the Johnnie oolite bed. Below this marked trend in the data, there is otherwise no general trend. 
Figure 7. (A) Detailed lithostratigraphic column of the Mount Schader section, from unit $\mathbf{G}$ of the Johnnie Formation through the lowermost part of the A Member of the Stirling Formation, showing thicknesses based on Jacobs staff measurements (transects shown in Fig. 6). Detailed descriptions of subunits 1-48 are given in the supplemental text (text footnote 1). (B) Carbon and (C) oxygen isotope ratios in carbonate, as a function of stratigraphic position. Numerical values are in Table $\mathbf{S} 1$ (text footnote 1). VPDB-Vienna Peedeo belemnite.

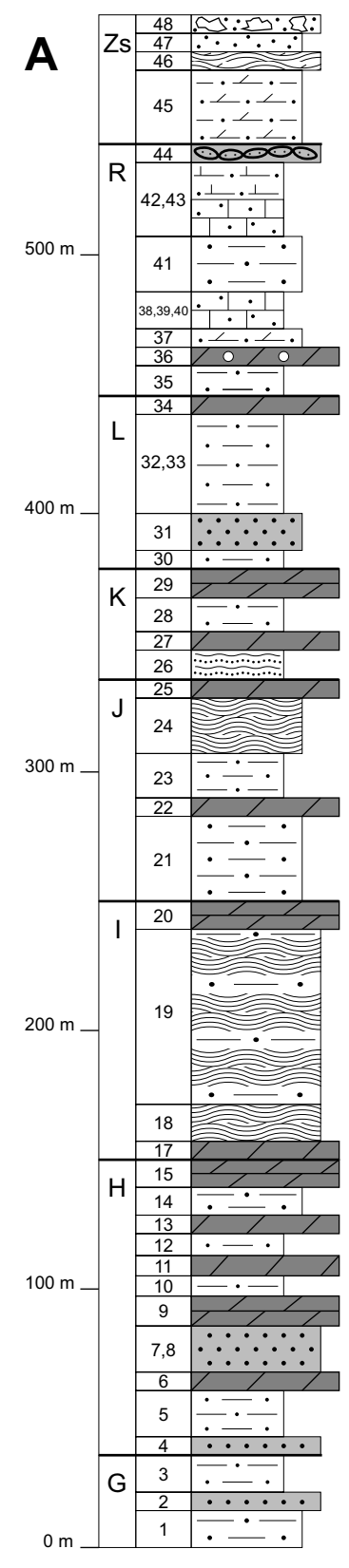

Stirling Formation: orthoquartzite (dolomitic, crossstratified, massive, or brecciated)

Rainstorm Member:

siltstone, Johnnie oolite,

sandy limestone, \&

orthoquartzite with

ball-and-pillow structure

\section{siltstone with rare}

orthoquartzite, \& brown

dolostone

ripple-bedded siltstone \&

brown dolostone

siltstone, hummocky crossstratified orthoquartzite \& brown doloston

hummocky cross-stratified orthoquartzite, siltstone,

\& brown dolostone
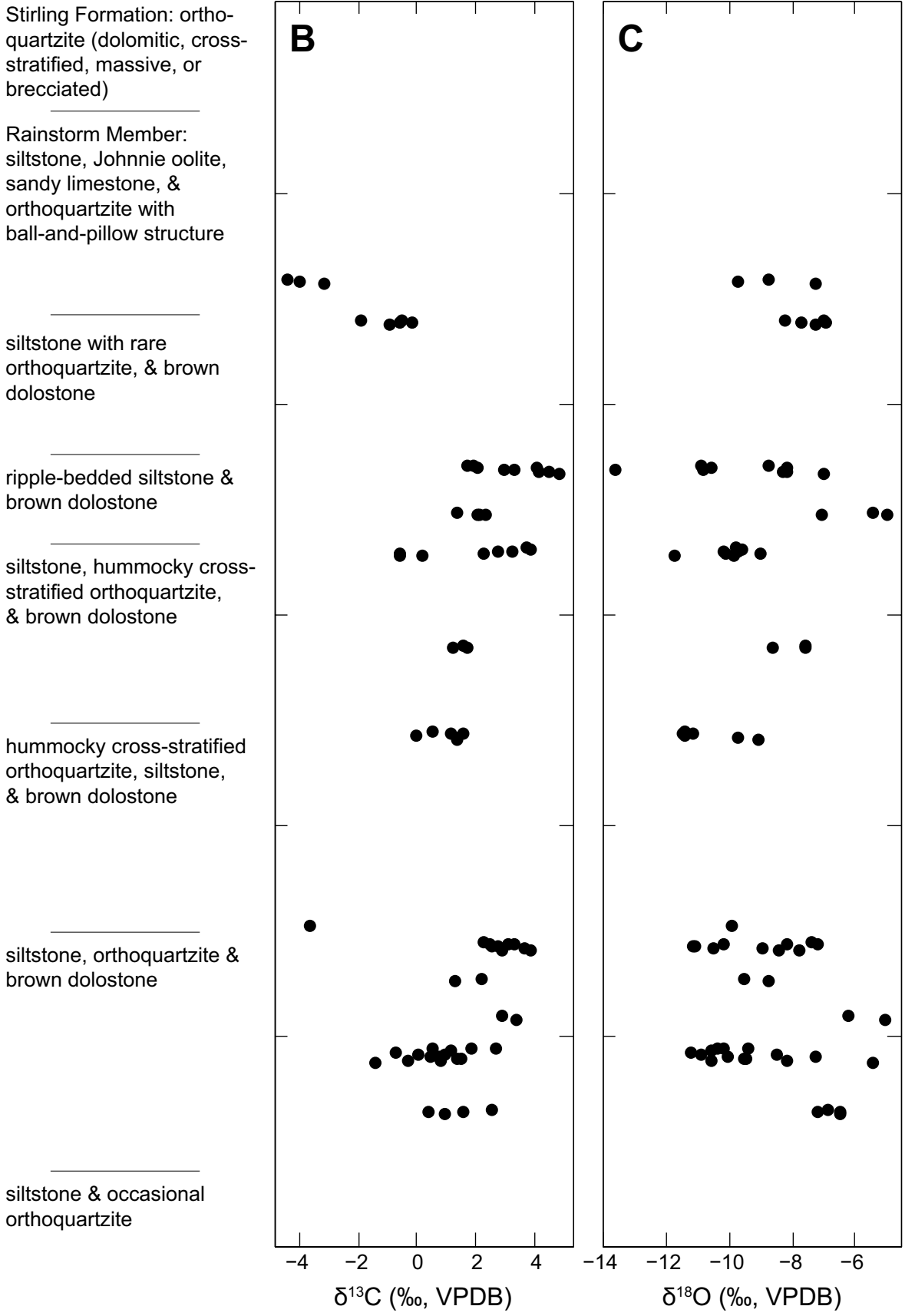


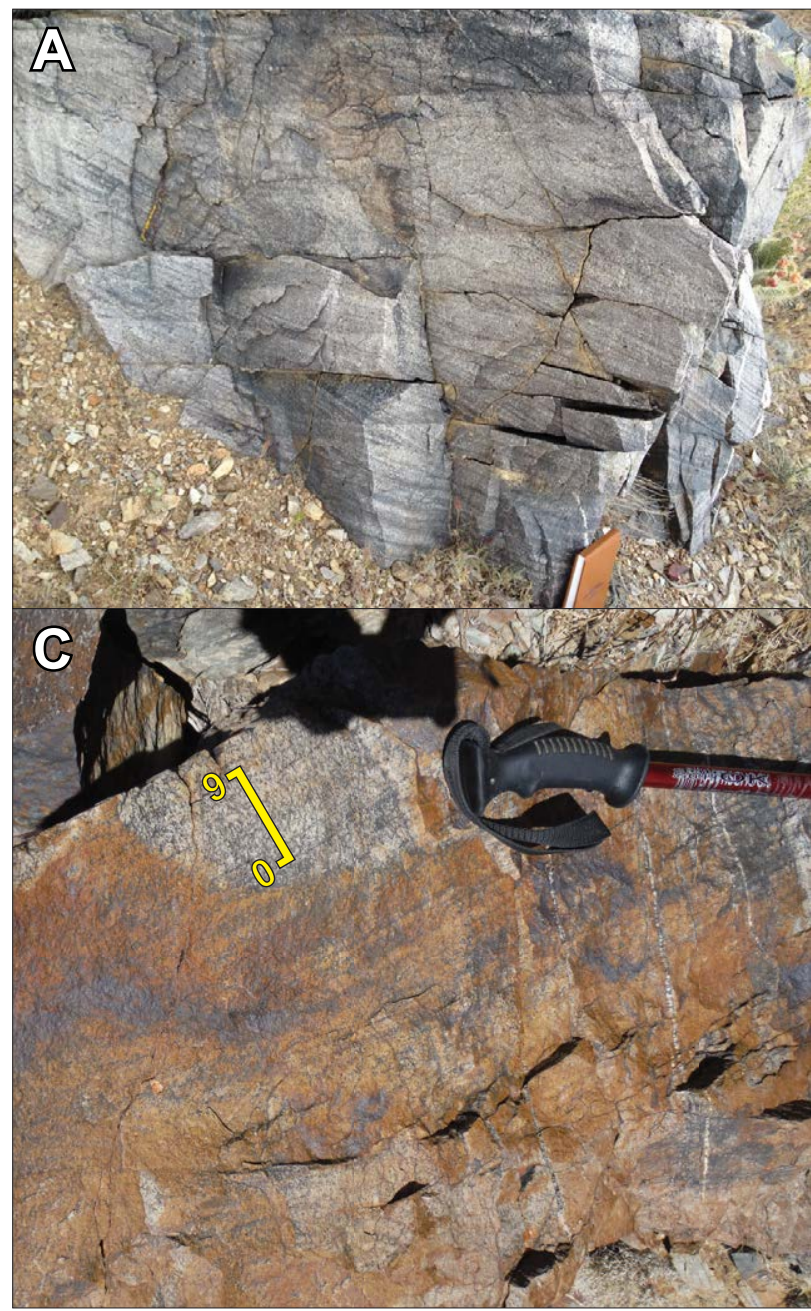

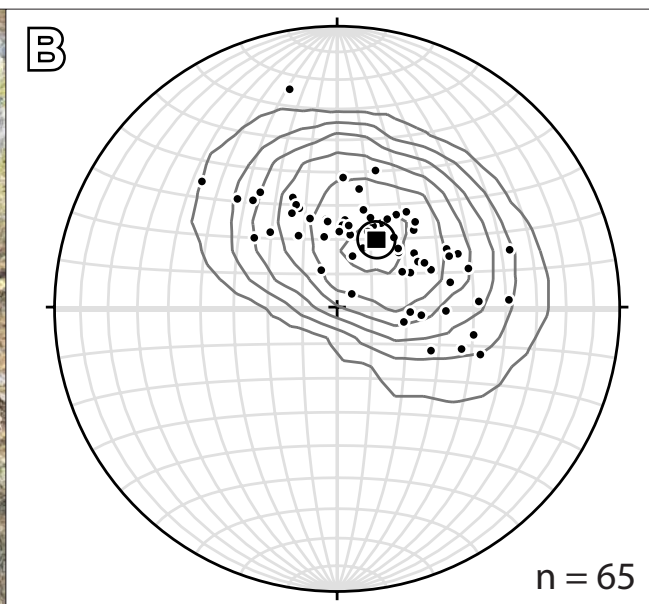

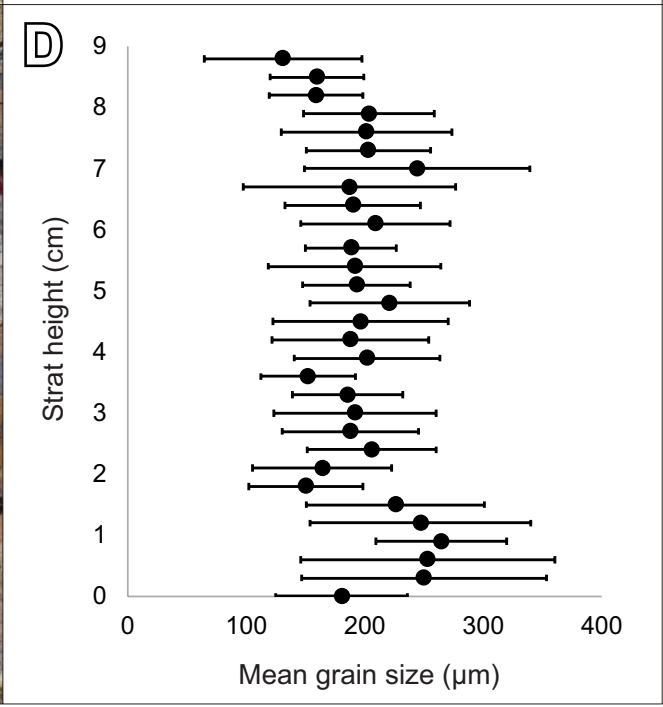

Figure 8. (A) Photograph of tabular planar cross-stratification in unit $D$, Johnnie Wash. Notebook is $13 \mathrm{~cm}$ wide. (B) Equalarea stereogram of poles to foreset lamnations measured at locality A (Fig. 2A), $(n=65)$. $(n=65)$; larger square in circle is the mean vector. Plotted using Stereonet software (Allmendinger et al., 2012, Cardozo and Allmendinger, 2013), with Kamb contours at $2 \sigma$ intervals (Kamb, 1959). (C) Photograph of steep foreset laminations (bedding parallel to base of photograph), showing $9 \mathrm{~cm}$ scale bar at location of petrographic measurements of mean grain size in $D$. (D) Mean grain size as a function of stratigraphic height in sample of foreset lamina$\mu \mathrm{m}$
More than $90 \%$ of the values recorded from the bottom of unit $K$ to the unit C carbonate are positive, averaging $1.5 \%$, with a standard deviation of $1.2 \%$. The scatter in values within individual carbonate intervals is approximately the same as variations in the average values between carbonate intervals (Fig. 7) However, the variation in $\delta^{13} \mathrm{C}$ values with stratigraphic position within each relatively thin carbonate interval does not appear to be entirely random (Fig 10). For example, carbonates from units $C$ and the lower part of unit $K$ show decreasing $\delta^{13} \mathrm{C}$ values stratigraphically upward $\left(R^{2}=0.74,0.88\right.$ respectively) whereas values from the lower two carbonates in unit $H$ and the upper carbon- ate interval in unit $\mathrm{J}$ suggest increasing $\delta^{13} \mathrm{C}$ values stratigraphically upward $\left(R^{2}=0.26-0.83\right)$.

Oxygen isotope ratios range from a low of $-16.0 \%$ (VPDB) to a high of $-5.0 \%$, with an average value of $-9.4 \%$ (Table $\mathrm{S} 1$ [footnote 1 ]). There is no general trend in the mean values for each individual carbonate interval with stratigraphic position (Fig. $7 \mathrm{C}$ ). The range of values within the carbonate intervals is as great as $6 \%$, i.e., greater than the variation of mean values for each interval. Correlation of $\delta^{18} \mathrm{O}$ and $\delta^{13} \mathrm{C}$ is poor for the data set as a whole (Fig. 11). Plots of $\delta^{18} \mathrm{O}$ versus stratigraphic position and side-by-side comparison with $\delta^{13} \mathrm{C}$ values 


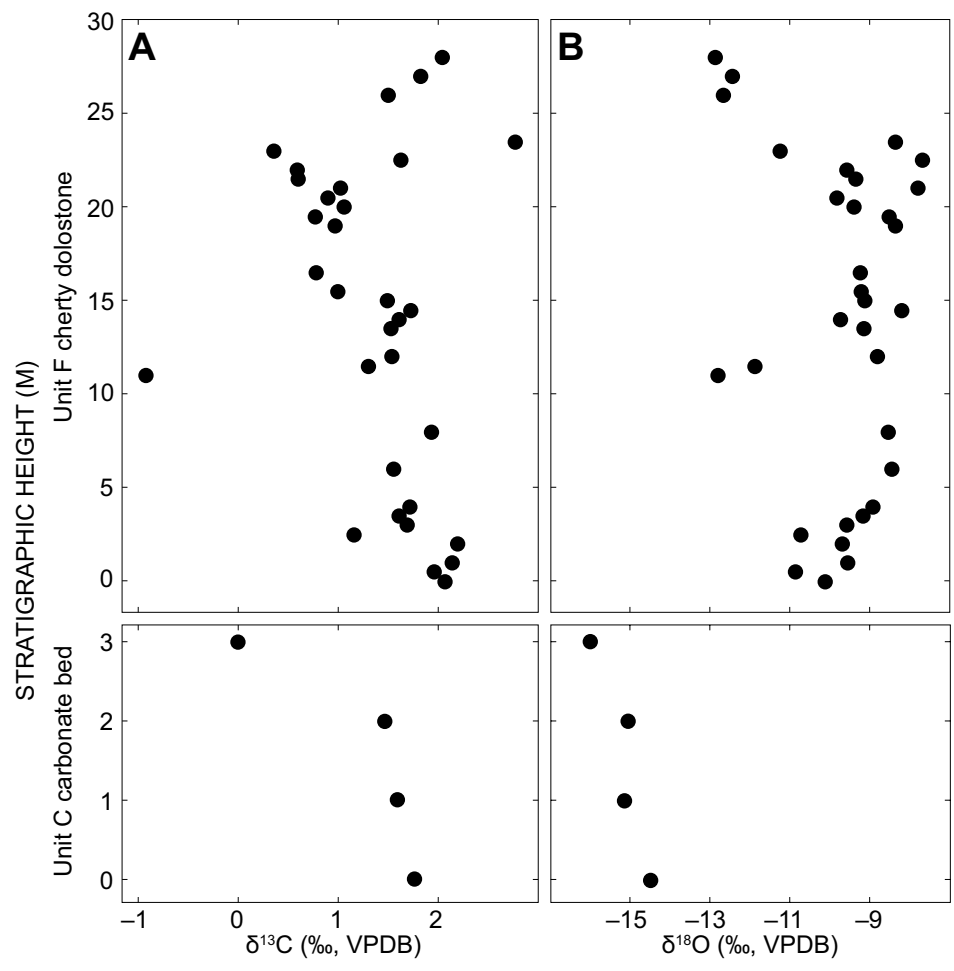

Figure 9. (A) Carbon and (B) oxygen isotope ratios in carbonate as a function of stratigraphic position for units $C$ and $F$ in the Johnnie Wash area. Numerical values are found in Table $\mathbf{S} 1$ (text footnote 1). VPDB - Vienna Peedee belemnite.

are presented in the Supplemental Items (Fig. S2 [footnote 1]). Correlation of $\delta^{18} \mathrm{O}$ values with stratigraphic position within each interval is also generally poor. Of 12 beds with more than three samples, $R^{2}>0.5$ only for beds Zjj1, Zji2, and Zjc (see Table 1 for nomenclature). With regard to correlation of $\delta^{18} \mathrm{O}$ with $\delta^{13} \mathrm{C}$, only the carbonate in unit $\mathrm{C}$ shows good positive correlation $\left(R^{2}=0.9\right)$, but this interval only has four data points. Intervals with 10 or more data points all show poor $\left(R^{2}<0.1\right)$ intrabed correlation of $\delta^{18} O$ with $\delta^{13} \mathrm{C}$ (Fig. S2 [footnote 1]).

\section{Subsidence Analysis}

Our analyses focused on modeling the tectonic component of subsidence for strata in the Spring Mountains section: Johnnie unit A through the Devonian Devils Gate Formation (Table 1). The model results define the relationship between the stratigraphic thickness $S$, and the tectonic component of subsidence $Y$ (Table 2), which yields a resulting curve for the function $Y(S)$ (Fig 12). This curve depends on parameters that describe lithification and isostatic adjustment due to sediment loading (Tables 2 and 3 ), and it is independent of time (Eqs. 1 and 2 in Steckler and Watts, 1978). We model the time dependence of subsidence in the Discussion section below.

Our determinations of $Y(S)$ include the effects of some $3000 \mathrm{~m}$ of Mississippian through Triassic overburden that lay above the Johnnie-Devils Gate interval during Jurassic and Early Cretaceous time (Giallorenzo et al., 2017). They also include two major sources of uncertainty. The first is the possible effect of a significant sedimentary substrate, predating Johnnie unit $A$, on the calculated tectonic subsidence. The substrate may either have been: (1) limited to the Noonday Formation or its equivalents, which are at most a few hundred meters thick and may be represented by the lowest units of the Johnnie Wash section (values $Y_{n s}$ indicate "no substrate"); or (2) a thick succession of Proterozoic Pahrump Group strata (Crystal Spring through Kingston Peak Formations), which could be present at depth beneath the northwest Spring Mountains (values $Y_{\text {ws }}$ indicate "with substrate"; note that in Fig. 12, $Y_{\text {ws }}$ values were plotted using the base of the Spring Mountains section as a datum for zero, for a direct comparison to $Y_{\text {ns }}$ ). The oldest Pahrump Group strata, the Crystal Spring Formation, were $\sim 500$ m.y. old in Ediacaran time, and therefore these models may somewhat overestimate the effect of sedimentary substrate on late Cryogenian-Ediacaran subsidence. The second major source of uncertainty lies in the resulting density of the delithified sediment column (Bond and Kominz, 1984; Bond et al., 1988). We simulated this error by varying sediment grain density by $\pm 5 \%$, and we note that the effect of sediment unloading is such that the lowest assumed density results in the highest tectonic component of subsidence, and vice versa. This density range yields variations in values of $Y$ for a given $S$ ( $Y_{\text {low }}$ or $Y_{\text {highi }}$ Table 4) that are similar to those obtained by Bond and Kominz (1984) and Levy and Christie-Blick (1991).

The resulting plots for $Y(S)$ (Fig. 12) show a decreasing ratio of tectonic subsidence per meter of sediment thickness, with slopes $(\Delta Y / \Delta S)$ ranging from values near 1.0 at the base of the section for the "no substrate" curves, to as little as 0.1 near the middle of the section for the "with substrate" curve. More typically, slopes range from 0.3 to 0.6 . There is an abrupt change in slope at $S \approx 3500 \mathrm{~m}$, where the section transitions from predominantly siliciclastic to predominantly carbonate sedimentation. On the no-substrate curve, the slopes defined by the five values closest to $S=3500 \mathrm{~m}$ are $0.5(S<3500 \mathrm{~m})$ and $0.2(S>3500 \mathrm{~m})$, with each of the two arrays appearing quite linear. Corresponding values on the "with substrate" curve are 0.4 and 0.1 . Thus, although there is a degree of gradual curvature above and below $S=3500 \mathrm{~m}$, most of the flattening of $Y(S)$ is associated with the lithologic transition.

The effect of including a thick substrate of Pahrump Group strata is to greatly reduce our estimate of $Y$ for any given $S$. In other words, by not accounting for the substrate, we overestimate the tectonic component of subsidence by $50 \%$ or more, particularly in the early phases of subsidence. Physically, the reason for this is that the no-substrate model inadvertently places incompressible basement rocks where a compacting substrate exists in the event that there is substrate, and therefore the model incorrectly assigns the compaction of the substrate to tectonic subsidence, resulting in an overestimate. 


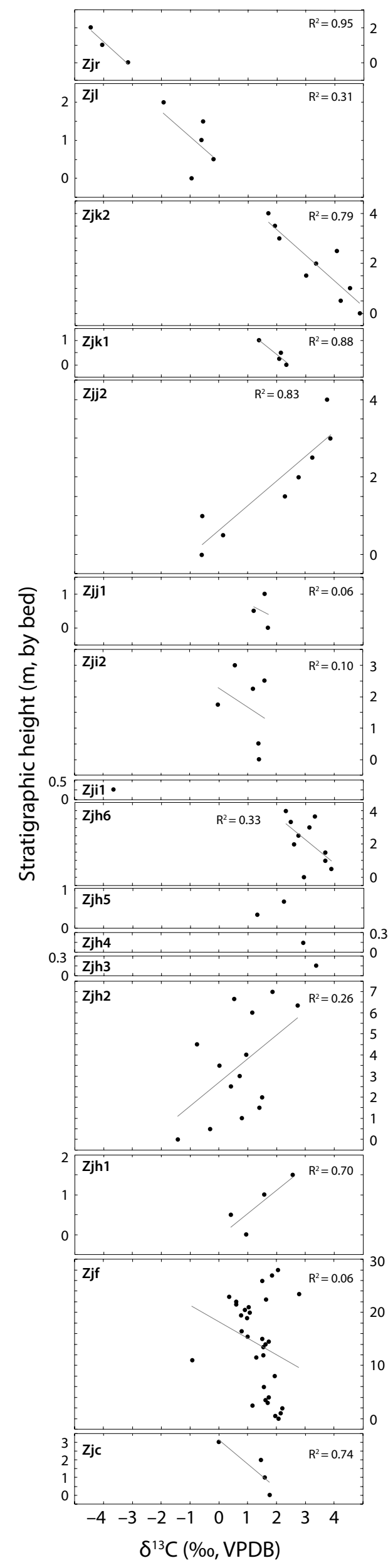

Figure 10. Carbon isotope ratios as function of stratigraphic position, expanding the vertical scale within each carbonate bed to reveal any intrabed trends. Beds are numbered from bottom to top within a given unit, e.g., $\mathrm{Zjj} 1$ is the lowest carbonate bed in unit J. VPDB-Vienna Peedee belemnite. 
TABLE 1. NOMENCLATURE OF STRATIGRAPHIC UNITS USED IN SUBSIDENCE ANALYSIS TABLES

\section{Spring Mountains section}

Carbonate overburden

Devils Gate Fm

Nevada Fm

Laketown Fm (upper 50\%)

Laketown Fm (lower 50\%)

Ely Springs Fm

Eureka Fm

MzPzco

Pogonip Group (upper third)

Pogonip Group (lower two thirds)

Nopah Fm (upper third)

Nopah Fm (lower two thirds)

Dunderberg Fm

Bonanza King Fm (Banded Mountain Mbr, upper 36\%)

Bonanza King Fm (Mbrs: Papoose Lake \& Banded Mountain, lower 64\%) Ebk1

Carrara Fm (upper two thirds)

Carrara Fm (lower third)

Zabriskie Fm

Wood Canyon Fm (Ediacaran-Cambrian boundary to top)

Wood Canyon Fm (to Ediacaran-Cambrian boundary)

Stirling Fm (members A through E)

Johnnie Fm (Rainstorm Mbr, oolite bed's base to top of Mbr)

Johnnie Fm (Rainstorm Mbr, base to oolite bed's base)

Johnnie Fm (members A through L)

Ddg

$\mathrm{Dn}$

DI

Oes

Oe

Op2

n2

Pahrump Group substrate (hypothetical)

Johnnie Fm (presumed equivalent to the Transitional Mbr of Stewart, 1970)

Kingston Peak Fm (Mbr: South Park, sub-Mbr: Wildrose)

Kingston Peak Fm (Mbr: South Park, sub-Mbr: Thorndike)

Kingston Peak Fm (Mbr: South Park, sub-Mbr: Mountain Girl)

Kingston Peak Fm (Mbr: South Park, sub-Mbrs: Sourdough \& Middle Park)

Kingston Peak Fm (Limekiln-Surprise Mbr)

Beck Springs Fm/Kingston Peak Fm (lower)

Horse Thief Springs Fm

Crystal Springs Fm (upper)

Crystal Springs Fm (lower)

Cbk1

€c2

$\epsilon z$

EZwc2

EZwc1

Zsa - Zs

Zjr2

Zja - Zj

Zjt
Zkpw
Zkpth
Zkpmg
Zkpsmp
Zkpls
Zbs
Zhs
Ycs2
Ycs1

TABLE 2. NOMENCLATURE FOR PARAMETERS USED IN DELITHIFICATION AND BACKSTRIPPING ANALYSIS ${ }^{\dagger}$

\begin{tabular}{lc}
$\phi_{0}$ & Surface porosity $(\%)$ \\
$c$ & Porosity depth coefficient $\left(\mathrm{km}^{-1}\right)$ \\
$\rho_{\mathrm{sg}}$ & Sediment grain density $\left(\mathrm{kg} \mathrm{m}^{-3}\right)$ \\
$h$ & Stratigraphic thickness $(\mathrm{m})$ \\
$S$ & Cumulative stratigraphic thickness $(\mathrm{m})$ \\
$S^{*}$ & Delithified/decompacted thickness $(\mathrm{m})$ \\
$Y$ & Tectonic subsidence $(\mathrm{m})$ \\
\hline \multicolumn{2}{r}{ 'Subscripts for $S, S^{*}$, and $Y:$ ns-no Pahrump Group substrate; } \\
ws-with Pahrump Group substrate; low-low subsidence, using \\
$+5 \% \rho_{\mathrm{sg}} ;$ high-high subsidence, using - $5 \% \rho_{\mathrm{sg}} \cdot$
\end{tabular}

each on the order of $100 \mathrm{~m}$ to a few hundred meters thick (I, II, III in Fig. 13 on the northern Spring Mountains section). The three sand-rich intervals of the Johnnie Formation are succeeded by four additional sand-rich intervals that have long been recognized as regionally correlative units (IV-VII in Fig.

13 on the northern Spring Mountains section), of which the top three have paleontological age constraints. The two sections each contain three sandrich intervals below the Rainstorm Member that have proportionate relative thicknesses. Further, the siltstone/carbonate-rich interval between sand-rich intervals II and III contains an $\sim 40-\mathrm{m}$-thick cherty dolostone unit in both sections, strengthening correlation, as noted by Stewart (1970) and Benmore (1978). We correlate sand-rich interval I of the Spring Mountains (unit B) with 


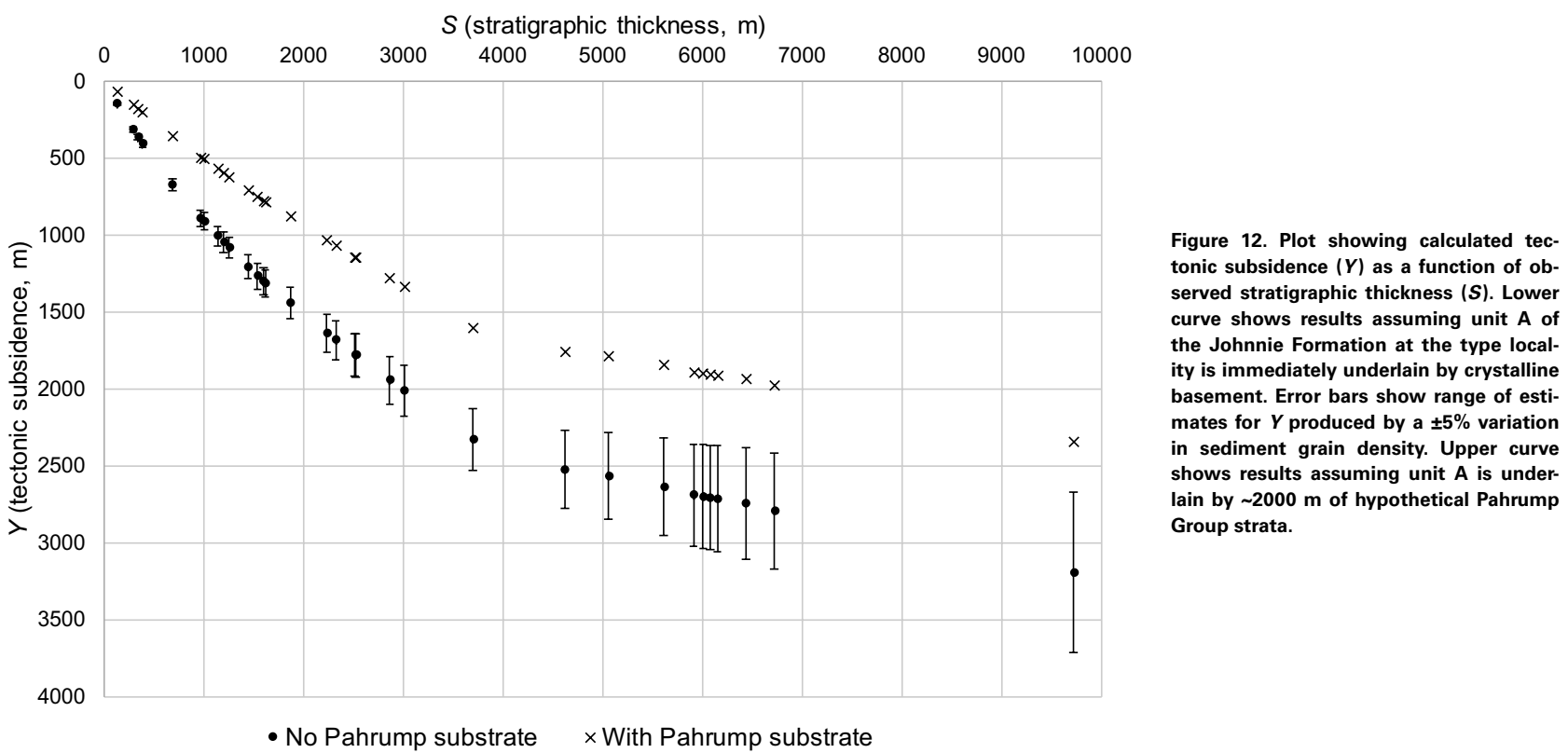

the Carbonate member in the Desert Range section, on the basis of stratigraphic position. We note, however, that the pervasive soft sediment deformation in unit $B$ has not been reported from orthoquartzites in the Carbonate member, and that unit $B$ does not contain carbonate. Unit $A$, which is predominantly siltstone, would therefore correlate with siltstones and oolitic limestones underneath the Carbonate member. The oolitic limestone unit at the base of the Desert Range section has been considered to be correlative with the Noonday Formation (Longwell et al., 1965; Gillett and Van Alstine, 1982), implying that unit $A$ in the Spring Mountains may also be a Noonday correlative (Fig. 13).

The southern Nopah Range section is approximately half the thickness of the northern Spring Mountains and Desert Range sections, and it contains a number of subaerial erosion surfaces that thus far have not been observed in the thicker Nevada sections (Summa, 1993). Like the Nevada sections, however, it does contain three sub-Rainstorm Member sand-rich intervals, suggesting lithostratigraphic correlation (Fig. 13). Specifically, the lower part of the Transitional, Quartzite, and Upper carbonate-bearing members of Stewart (1970) would correspond to sand-rich intervals I, II, and III, respectively, in the Spring Mountains. The correlation is strengthened by: (1) the alternating orthoquartzite/carbonate cycles evident in sand-rich interval III in both the northern Spring Mountains and southern Nopah Range sections; (2) the lack of carbonate and abundance of high-angle cross-stratification in interval II in all three sections (Quartzite member = upper part of Lower quartzite and siltstone member = unit D, Fig. 13); (3) the consistency of unimodal, south-southwestdirected paleoflow directions in pre-Rainstorm Member orthoquartzites in the Spring Mountains and Desert Range sections (Fig. 14); and (4) the lithological similarity between the lowest sand-rich intervals in the southern Nopah Range and Desert Range sections, both of which contain a mixed carbonate-siliciclastic assemblage. Militating against these lithostratigraphic correlations are the observations that: (1) the interval III correlative in the Desert Range lacks carbonate; (2) interval I in the Spring Mountains (unit B) also lacks carbonate and (3) the proposed Noonday substrate of interval I is lithostratigraphically dissimilar in all three sections, ranging from pale-gray quartz-rich dolomite boundstone in the Nopah Range, to phyllitic siltstone in the Spring Mountains, to medium-gray oolitic limestone in the Desert Range. Regardless of the details of these correlations, the most important facets of the two sections in Nevada are the following: (1) The sub-Rainstorm Member sections are at least twice as thick as the Nopah Range section; and (2) evidence for subaerial erosion, such as grikes, paleosols, channel scour, and desiccation cracks, which is conspicuous in the Nopah Range section, appears to be lacking. Although significant depositional hiatuses within the Nevada sections cannot be ruled out, the overall lithostratigraphic uniformity or "monotony" of these sections (siltstone and fine- to medium-grained sandstone and orthoquartzite, with sporadic thin carbonate beds) is consistent with conformable sedimentation on a stably subsiding continental shelf (Stewart, 1970; Fedo and Cooper, 2001; Schoenborn et al., 2012). 


\begin{tabular}{|c|c|c|c|c|c|c|c|c|}
\hline Unit & $\begin{array}{l}\mathrm{Age}^{\S} \\
(\mathrm{Ma})\end{array}$ & Lithology & $\begin{array}{c}\phi_{0} \\
(\%)\end{array}$ & $\begin{array}{c}c \\
\left(\mathrm{~km}^{-1}\right)\end{array}$ & $\begin{array}{c}\rho_{\mathrm{sg}} \\
\left(\mathrm{kg} \mathrm{m}^{-3}\right)\end{array}$ & $\begin{array}{c}h \\
(\mathrm{~m})\end{array}$ & $\begin{array}{l}S_{\mathrm{ns}} \\
(\mathrm{m})\end{array}$ & $\begin{array}{l}S_{\text {ws }} \\
(\mathrm{m})\end{array}$ \\
\hline MzPzco\# & Ca. 243 & $1 / d$ & 43 & 0.58 & 2785 & 3000 & 9720 & 11745 \\
\hline Ddg & 359 & $d$ & 43 & 0.58 & 2710 & 286 & 6720 & 8745 \\
\hline Dn & 383 & $d$ & 43 & 0.58 & 2860 & 286 & 6434 & 8459 \\
\hline DI & 393 & $d$ & 43 & 0.58 & 2860 & 71.5 & 6148 & 8173 \\
\hline SI & 419 & $d$ & 43 & 0.58 & 2860 & 71.5 & 6076.5 & 8101.5 \\
\hline Oes & 444 & $d$ & 43 & 0.58 & 2860 & 95 & 6005 & 8030 \\
\hline $\mathrm{Oe}$ & 458 & $\mathrm{~s}$ & 49 & 0.27 & 2650 & 71 & 5910 & 7935 \\
\hline Op2 & - & 1 & 43 & 0.58 & 2710 & 230 & 5839 & 7864 \\
\hline Op $1^{\star *}$ & 470 & 1 & 43 & 0.58 & 2710 & 460 & 5609 & 7634 \\
\hline OEn2 & - & $\mathrm{d}$ & 43 & 0.58 & 2860 & 95 & 5149 & 7174 \\
\hline O€n1 & 485 & $d$ & 43 & 0.58 & 2860 & 191 & 5054 & 7079 \\
\hline$€ d$ & - & sh & 63 & 0.51 & 2720 & 48 & 4863 & 6888 \\
\hline Ebk2 & - & $d$ & 43 & 0.58 & 2860 & 197 & 4815 & 6840 \\
\hline Ebk1 & 497 & $d$ & 43 & 0.58 & 2860 & 637 & 4618 & 6643 \\
\hline$\epsilon c 2$ & - & sh & 63 & 0.51 & 2720 & 286 & 3981 & 6006 \\
\hline$\epsilon c 1$ & 509 & sh & 63 & 0.51 & 2720 & 143 & 3695 & 5720 \\
\hline$\epsilon z$ & - & $\mathrm{s}$ & 49 & 0.27 & 2650 & 24 & 3552 & 5577 \\
\hline$€ Z w c 2$ & - & s/slt & 49 & 0.27 & 2650 & 523 & 3528 & 5553 \\
\hline$€ Z w c 1$ & 541 & s/slt & 49 & 0.27 & 2650 & 144 & 3005 & 5030 \\
\hline Zse & - & $\mathrm{s}$ & 49 & 0.27 & 2650 & 340 & 2861 & 4886 \\
\hline $\mathrm{Zsd}^{\dagger+}$ & - & $\mathrm{d}$ & 46 & 0.43 & 2755 & 10 & 2521 & 4546 \\
\hline Zsc & - & $\mathrm{slt} / \mathrm{s}$ & 49 & 0.27 & 2650 & 190 & 2511 & 4536 \\
\hline Zsb & - & s/slt & 49 & 0.27 & 2650 & 90 & 2321 & 4346 \\
\hline Zsa & - & $\mathrm{s}$ & 49 & 0.27 & 2650 & 369 & 2231 & 4256 \\
\hline Zjr2§§ & - & slt/s/l/d & 47 & 0.37 & 2695 & 250 & 1862 & 3887 \\
\hline Zjr1"\#\# & - & slt & 49 & 0.27 & 2650 & 17 & 1612 & 3637 \\
\hline Zjl & - & s/slt & 49 & 0.27 & 2650 & 60 & 1595 & 3620 \\
\hline Zjk & - & s/slt & 49 & 0.27 & 2650 & 95 & 1535 & 3560 \\
\hline Zjj & - & s/slt & 49 & 0.27 & 2650 & 190 & 1440 & 3465 \\
\hline Zji & - & s/slt & 49 & 0.27 & 2650 & 55 & 1250 & 3275 \\
\hline Zjh & - & s/slt & 49 & 0.27 & 2650 & 60 & 1195 & 3220 \\
\hline Zjg & - & slt & 49 & 0.27 & 2650 & 135 & 1135 & 3160 \\
\hline Zjf*** & - & $\mathrm{d}$ & 43 & 0.58 & 2860 & 40 & 1000 & 3025 \\
\hline Zje & - & s/slt & 49 & 0.27 & 2650 & 280 & 960 & 2985 \\
\hline Zjd ${ }^{\dagger+\dagger}$ & - & $s$ & 49 & 0.27 & 2650 & 300 & 680 & 2705 \\
\hline Zjc2 & - & slt & 49 & 0.27 & 2650 & 45 & 380 & 2405 \\
\hline Zjc1§§§ & - & slt & 49 & 0.27 & 2650 & 50 & 335 & 2360 \\
\hline Zjb\#\#\# & - & $s$ & 49 & 0.27 & 2650 & 160 & 285 & 2310 \\
\hline Zja & - & slt & 49 & 0.27 & 2650 & 125 & 125 & 2150 \\
\hline$Z j t^{\star \star * *}$ & - & $d / s$ & 46 & 0.43 & 2755 & 125 & - & 2025 \\
\hline Zkpw ${ }^{\dagger+t \dagger}$ & 635 & ss & 49 & 0.27 & 2650 & 100 & - & 1900 \\
\hline Zkpth & - & $d$ & 43 & 0.58 & 2860 & 100 & - & 1800 \\
\hline Zkpmg & - & $s$ & 49 & 0.27 & 2650 & 100 & - & 1700 \\
\hline Zkpsmp & - & slt & 49 & 0.27 & 2650 & 200 & - & 1600 \\
\hline Zkpls & - & $\mathrm{s} / \mathrm{cgl}$ & 49 & 0.27 & 2650 & 400 & - & 1400 \\
\hline Zbs & - & $\mathrm{d}$ & 43 & 0.58 & 2860 & 200 & - & 1000 \\
\hline Zhs ${ }^{\S \S \S \S}$ & $<787$ & $\mathrm{~s}$ & 49 & 0.27 & 2650 & 200 & - & 800 \\
\hline Ycs2 & $>1087$ & $d$ & 43 & 0.58 & 2860 & 200 & - & 600 \\
\hline Ycs1\#\#\#\# & - & $\mathrm{s}$ & 49 & 0.27 & 2650 & 400 & - & 400 \\
\hline
\end{tabular}

'Values from table 9.1 in Allen and Allen (2005), Equation 3 in Halley and Schmoker (1983), Deer et al. (1992), or weighted averages for lithologic mixtures. Abbreviations for lithology are: $s$-sandstone; slt—siltstone; I-limestone; d-dolostone; sh-shale; cgl—conglomerate. See Table 2 for parameter definitions.

$\S$ Ages are at top of unit.

\#Lithologic ratio used is $50 / 50$; average for $\rho_{\text {sg. }}$.

${ }^{\star *}$ Carbonate is mostly limestone (fig. 2 in Burchfiel et al., 1974) .

${ }^{+t}$ Dolostone is sandy (stratigraphic column for Spring Mountains, plate 2 in Stewart, 1970).

$\S \S$ Shuram excursion ends. Lithologic ratio is $\mathrm{slt}+\mathrm{s} / \mathrm{l} / \mathrm{d}=67 / 16.5 / 16.5$ (table 3 in Stewart, 1970).

\#Shuram excursion begins.

${ }^{\star * \star}$ Cherty dolostone.

${ }^{+t+H}$ High-angle cross-bedding.

§§Onset of thermal subsidence (based on interpretation of ball-and-pillow structure; see text).

\#\#\#Ball-and-pillow structure.

$\star \star \star \star$ Lithologic ratio is $\mathrm{d} / \mathrm{s}=50 / 50$

${ }^{+t+t}$ Age from Petterson et al. (2011).

§§§Maximum age from Mahon et al. (2014).

\#\#\#Minimum age from Heaman and Grotzinger (1992). 
TABLE 4. RESULTS FROM DELITHIFICATION AND BACKSTRIPPING ANALYSIS OF THE SPRING MOUNTAINS SECTION ${ }^{\dagger}$

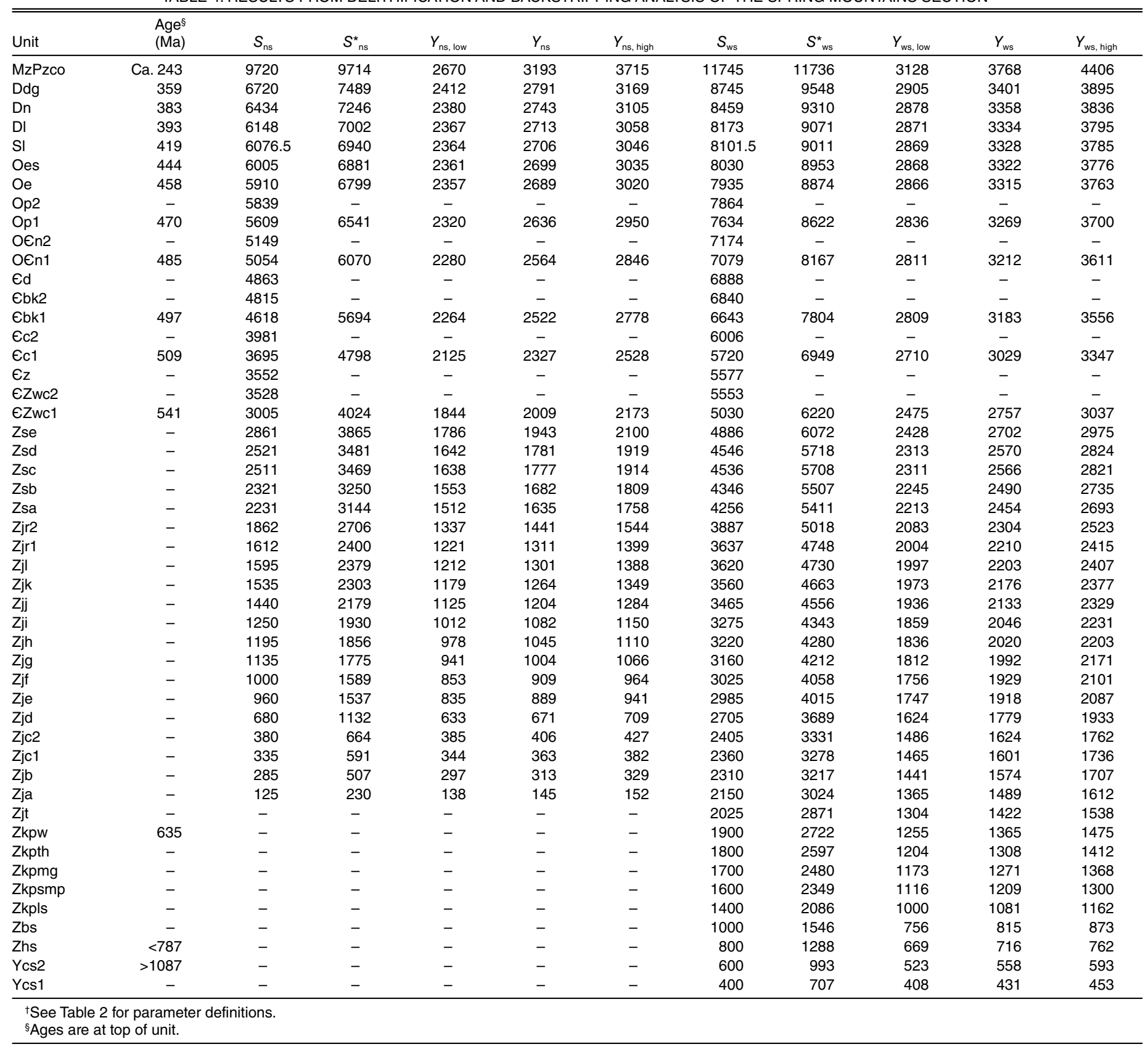


Spring Mountains (this study)

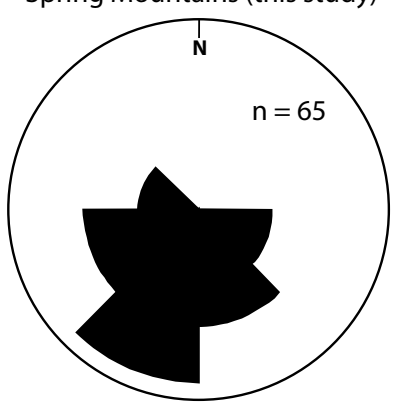

Spring Mountains (Benmore, 1978)

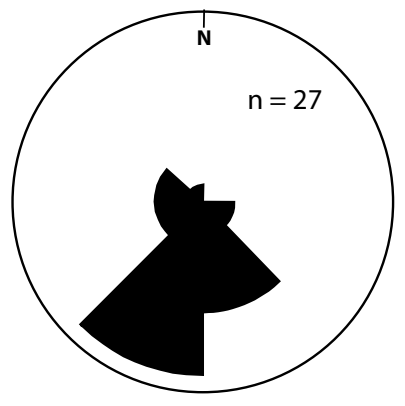

Desert Range (Benmore, 1978)

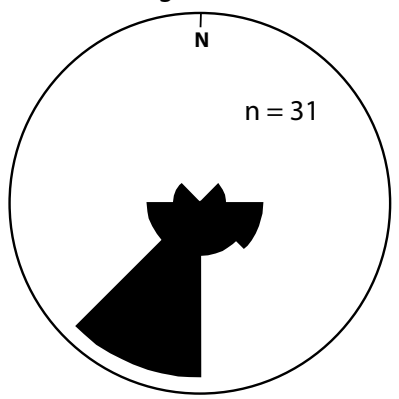

the ubiquity of meter-scale interbeds of fine- to medium-grained sandston overlying fine-grained sandstone or siltstone throughout the section. Thus, the cause (or causes) of soft-sediment deformation appears to be temporally restricted to, at most, sand-rich interval I and enveloping siltstone units $A$ and $\mathrm{C}$, and it presumably ended by the time of deposition of sand-rich interval (unit $D$ ). If it is assumed that the cause is earthquakes, then sand-rich intervals I and II record a transition from frequent seismic shaking to apparent seismic quiescence. Such an interpretation is consistent with previous suggestions that the end of mechanical stretching may have occurred near the base of the Johnnie Formation (Summa, 1993; Fedo and Cooper, 2001; Schoenborn et al., 2012). A ready alternative to a seismic trigger, however, is the effect of pressure contrasts from storm waves, which have also been shown to induce liquefaction and soft sediment deformation, including ball-and-pillow structure (Alfaro et al., 2002).

\section{Chemostratigraphy}

A composite plot of $\delta^{13} \mathrm{C}$ values of carbonate from the Johnnie Formation in southwest Laurentia (Verdel et al., 2011; this study) yields an overall pattern that is similar to profiles in Oman that contain the Shuram excursion, including a period of positive values as high as $4 \%{ }_{0}-6 \%$, rapid descent to values as low as $-11 \%$ to $-12 \%$, and a more gradual rise back to positive values (Fig. 15) The uniformly positive $\delta^{13} \mathrm{C}$ values below the excursion in southwest Laurentia, generally of $1 \%-3 \%$, invite detailed comparison with chemostratigraphic profiles in the carbonate-rich Khufai Formation in Oman, which lies immediately below the type Shuram excursion. The stratigraphic thickness of units between the zero crossings of the Shuram excursion in Oman and southwest Laurentia are similar, $500-700 \mathrm{~m}$ (Verdel et al., 2011). We therefore compared our profile to those from Oman without any modification to the vertical scaling (stratigraphic height), fixing the zero crossings at the base of the Shuram excursion at the same height. The Khufai sections in general are positive in $\delta^{13} \mathrm{C}$ and show considerable variation, depending on the degree of diagenetic alteration. In least-altered sections (Mukhaibah Dome area), maximum values range up to $6 \%$, averaging $4 \%-5 \%$ (Fig. $16 \mathrm{~A}$ ), i.e., considerably more positive than the Johnnie Formation profile. In more-altered sections (Buah Dome area; Fig. 16B), the profiles are quite similar to that of the Johnnie Formation. Given the close correspondence between the Johnnie profile and most of the Oman profiles (Fig. S3 [footnote 1]), we conclude that the data are consistent with, but do not absolutely demonstrate, temporal correlation between the upper part of the sub-Rainstorm Member Johnnie Formation (units $\mathrm{H}$ through $\mathrm{L}$ in the Spring Mountains) and the Khufai Formation.

The least-altered Khufai sections are generally considered to be representative of seawater carbon isotopic composition, defining a prolonged interval of $\delta^{13} \mathrm{C}$ values in seawater near $6 \%$. Therefore, it seems clear that subsequent diagenesis was primarily responsible for reducing $\delta^{13} \mathrm{C}$ values, in both Oman and the sub-Rainstorm Member Mount Schader section, by as much as $4 \%$ $5 \%$. In the Pleistocene environment, such reduction has been shown to result from carbon isotopic exchange between carbonate beds and meteoric water often resulting in $\delta^{13} \mathrm{C}$ values decreasing stratigraphically upward at the scale of a few meters in beds exposed to erosion (Allan and Matthews, 1977, 1982 Quinn, 1991; Melim et al., 1995, 2001). The strong intrabed variations in $\delta^{13} \mathrm{C}$ values in 1-2-m-thick carbonate intervals in the Johnnie Formation (Fig. 10) could potentially be explained by this mechanism, although $\delta^{13} \mathrm{C}$ values of meteoric water at that time are poorly constrained and may not have been as 


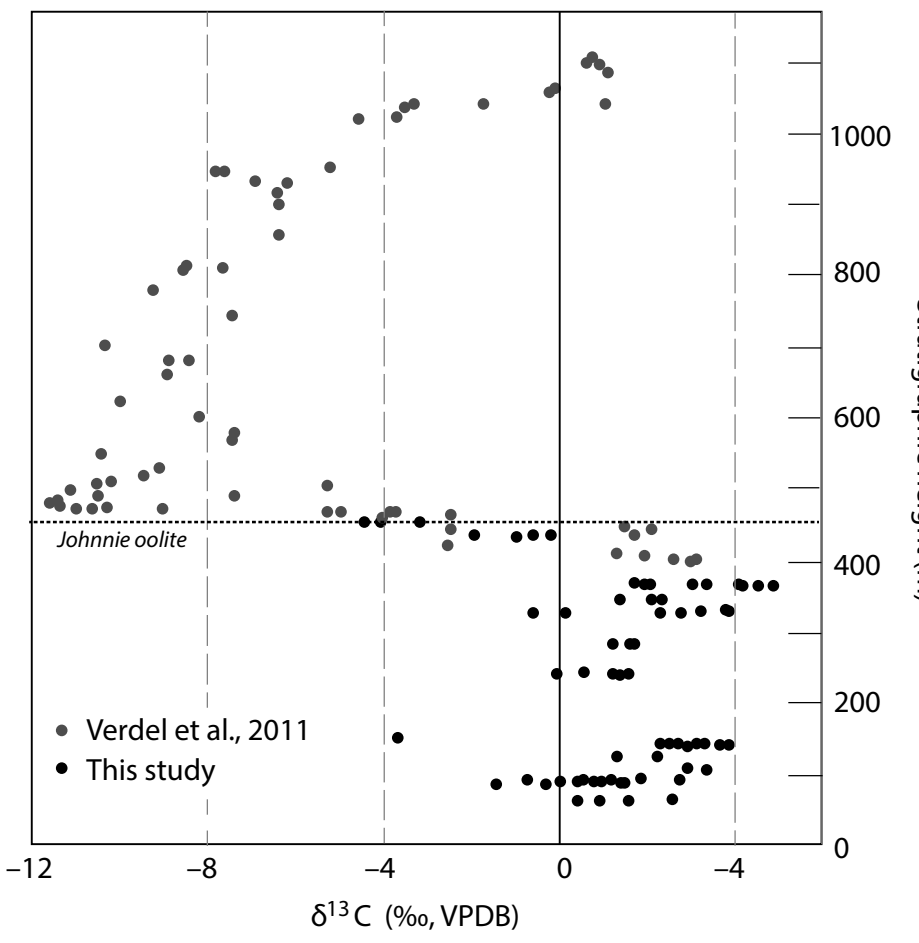

Figure 15. Composite chemostratigraphy of the upper Johnnie Formation, showing carbon isotopic ratios in carbonate from unit $\mathrm{H}$ up to the oolite marker horizon in the lowermost Rainstorm Member (Mount Schader section, this study) and values from just below the base of the Rainstorm Member to the top of the member (southern Panamint Range; Verdel et al., 2011). VPDB-Vienna Peedee belemnite.

strongly negative as modern values. Further, the intrabed trends in $\delta^{13} \mathrm{C}$ values both increase and decrease downward, and there is no evidence of subaeria exposure on the tops of any of the beds. As with most Neoproterozoic carbonates, determining the mechanisms of depletion of $\delta^{13} \mathrm{C}$ values and their relationship to diagenetic textures and the biosphere is a difficult and controversial issue (Knauth and Kennedy, 2009; Derry, 2010a, 2010b; Grotzinger et al., 2011), and it is beyond the scope of this paper to resolve. One thing we can say, however, about the Mount Schader data set is that it displays no clea correlations between $\delta^{18} \mathrm{O}$ and $\delta^{13} \mathrm{C}$ (Fig. 11), as predicted by various isotopic exchange models (fig. 4 in Osburn et al., 2015). Despite this controversy, the good match between the type Johnnie Formation sub-Rainstorm Membe section and the Khufai Formation supports the hypothesis that regardless of the origin of the anomalies, they nonetheless appear to be a useful correlation tool (Grotzinger et al., 2011). Tectonic reconstructions of the Neoproterozoic continent Rodinia put both the Shuram and the Johnnie formations roughly at the equator in Ediacaran time, but the two formations were located anywhere from 10,000 to $15,000 \mathrm{~km}$ away from each other (Li et al., 2008, 2013) making the isotopic correlation of the Shuram and sub-Shuram intervals all the more impressive.

One of the hallmarks of Neoproterozoic glacial cap carbonates is their frequent occurrence as thin, isolated intervals amid large thicknesses of enveloping strata that are entirely siliciclastic. Below unit $\mathrm{H}$, there are two such isolated carbonate intervals, one in unit $\mathrm{C}$ and the other composing the entirety of unit F. Given their stratigraphic position between the Marinoan cap carbonate sequence and the base of the Cambrian, it is possible that either one of these units represents postglacial carbonate "rainout," for example, as might be expected in the more southerly latitudes in the wake of the Gaskiers glaciation at $579 \mathrm{Ma}$ (e.g., Pu et al., 2016). The generally positive $\delta^{13} \mathrm{C}$ values in the unit $\mathrm{C}$ and unit $\mathrm{F}$ carbonates, averaging between $1 \%$ and $2 \%$, argue strongly against either of these intervals representing a Gaskiers cap carbonate, which in Newfoundland yielded $\delta^{13} \mathrm{C}$ values of $-8 \%$ o to $-2 \%$ (Myrow and Kaufman, 1999). Further, textural features widely described from cap carbonates (e.g., sheet cracks, tubes, teepee structures, etc.) are not observed in either of these intervals.

\section{Subsidence Analysis}

The substantial thickness of the Johnnie Formation, lack of evidence for unconformities in the Nevada sections, and the strengthened isotopic tie to the type Shuram excursion, motivate the hypothesis that the Noonday through lower Wood Canyon interval records continuous deposition through most or all of Ediacaran time. In the last section, backstripping and decompaction defined tectonic subsidence $Y$ as a function of stratigraphic position $S$, independent of time. In this section, we model the element of time as exponential subsidence, assuming that Johnnie Formation and subsequent deposition of the passive-margin wedge occurred as a result of conductive cooling of rifted lithosphere. Subsidence analysis with well-defined ages at the Cambrian-Precambrian boundary ( $541 \mathrm{Ma}$ ) and at the base of Cambrian Age 5 (509 Ma) creates a considerably improved basis over previous studies for estimating stratigraphic age in Ediacaran strata by extrapolating the subsidence history back in time.

Regardless of the absolute elevation following mechanical extension of the lithosphere, once thermal subsidence begins, the elevation $e$ of the surface, above its equilibrium value at $t=\infty$, is closely approximated by:

$$
e(t) \cong E_{0} r \mathrm{e}^{-\frac{t}{\tau}},
$$

where $E_{0} r$ is the elevation of stretched lithosphere above its equilibrium depth at infinite time (or in the case of infinite stretching, the height of the ocean floor above the abyssal plains), $t$ is time, $\tau$ is the characteristic time (time at which $\left.\frac{e}{E_{0} r}=\frac{1}{\mathrm{e}}\right)$ and 


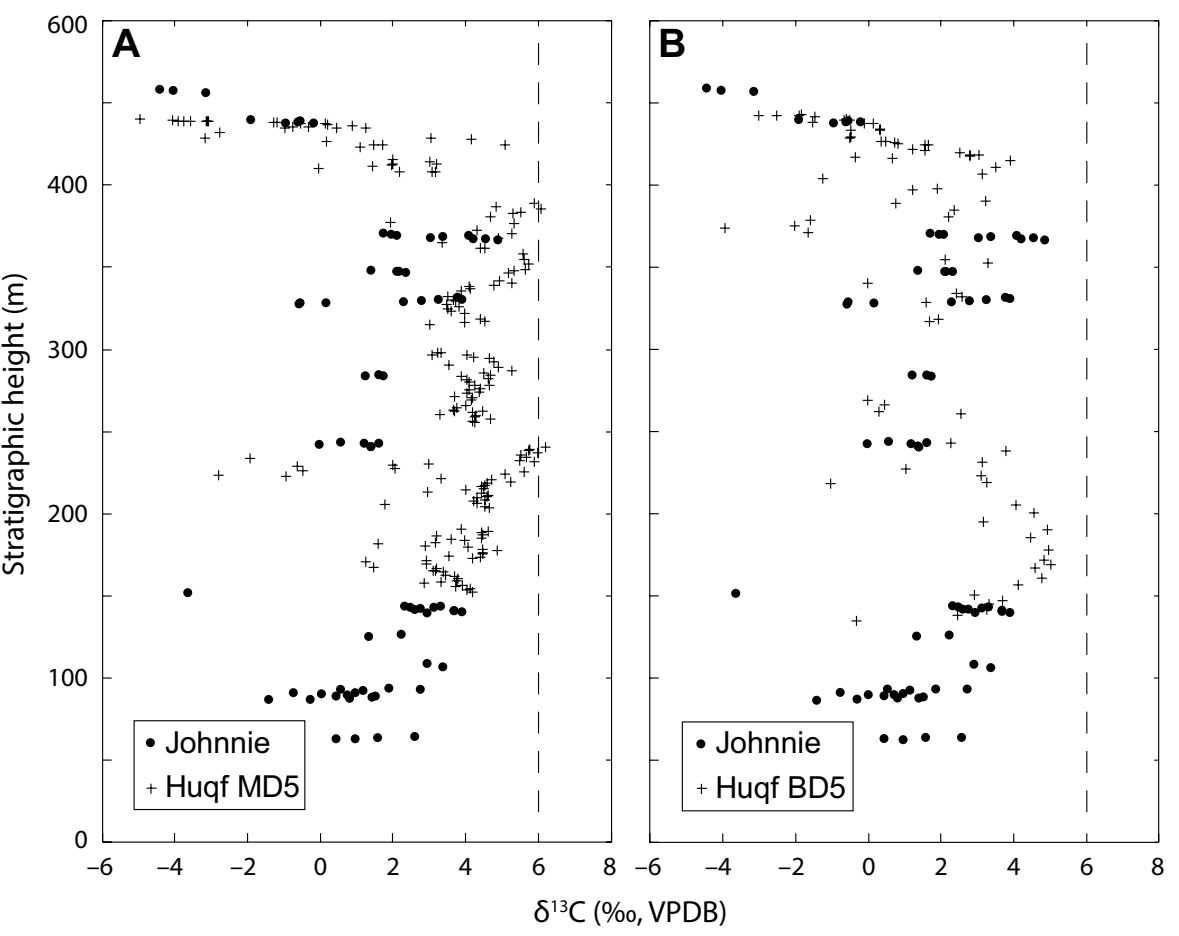

Figure 16. Chemostratigraphic profiles comparing carbon isotopic data from the Johnnie Formation from unit $\mathrm{H}$ through the lowermost Rainstorm Member (ending at the top of the oolite marker bed Fig. 7) with profiles from (A) the Mukhaibah Dome (MD5) and (B) the Buah Dome (BD5) areas of Oman (Osburn et al., 2015). Vertical axis shows measured stratigraphic height in all profiles. Six additional profile comparisons are presented in Fig ure S3 (text footnote 1). VPDB-Vienn Peedee belemnite.

$$
r=\frac{\beta}{\pi} \sin \frac{\pi}{\beta}
$$

where $\beta$ is the stretching factor (Fig. 17; see Eqs. 10 and 11 in McKenzie, 1978). $E_{0}$ and $r$ are not parameters of interest when using subsidence as a chronometer, because we are attempting to use the late history of postrift subsidence, which is well dated, to constrain the earlier history of postrift subsidence, which is not. The simple exponential formula for elevation versus time $e(t)$ of Equation 1 is converted to subsidence depth $Y$ versus time by substituting $\left(E_{0} r-Y\right)$ for $e$, yielding:

$$
Y(t) \cong E_{0} r\left(1-\mathrm{e}^{-\frac{t}{\tau}}\right) .
$$

In the case of mid-ocean ridges, where $\beta=\infty$ and $r=1, E_{0} r$ is empirically shown to be within a few percent of $3.2 \mathrm{~km}$ (Parsons and Sclater, 1977). We note that this value does not correspond to the actual ridge elevation above the abyssal plain, which is much higher for oceanic crust less than 20 m.y. old. The characteristic time $\tau$, which depends on the thermal diffusivity and thickness of equilibrium lithosphere, shows somewhat greater variation depending on the ridge $( \pm 10 \%$ for the best-constrained ridges; table 1 in Parsons and

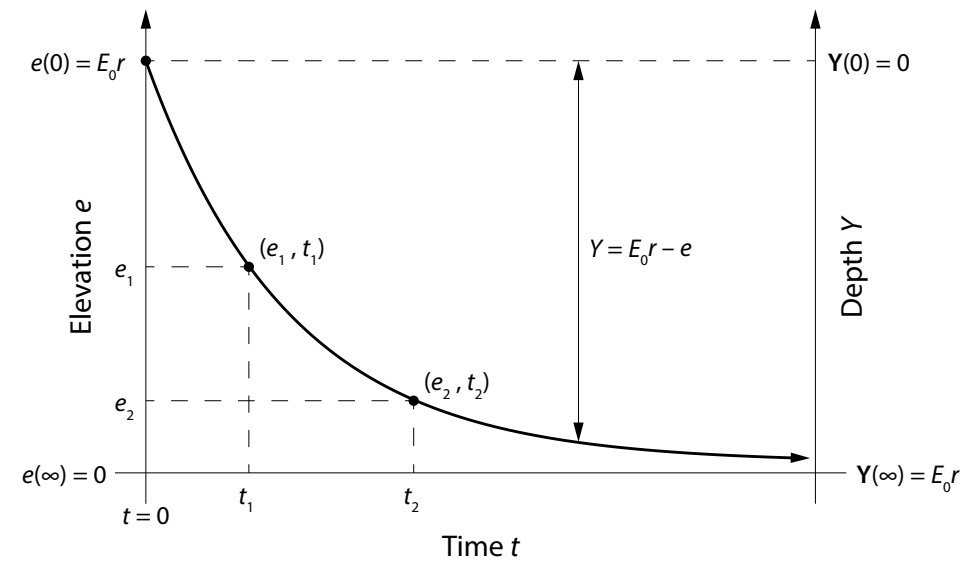

Figure 17. Plot showing an exponential subsidence model $Y(t)$, based on conductive cooling of extended lithosphere (McKenzie, 1978). Plotted on curve are the onset of thermal subsidence at $t=0$, and two arbitrary points in the history of subsidence. Note that so long as the stratigraphic position of $e(\infty)=0$ is well defined, the form of the subsidence curve, including the exponential decay constant $\tau$, is uniquely determined and does not depend on $e(0)=E_{0} r$. 
Sclater, 1977), but a generally accepted range of values in subsidence analyses of passive margins is 50-65 m.y. (McKenzie, 1978; Allen and Allen, 2005). This corresponds to a "half-life" of thermal subsidence of 35-45 m.y. Even though this key parameter may vary significantly, we can estimate $\tau$ directly from our subsidence model, as an independent test of the hypothesis that the margin is in a state of exponential thermal subsidence, comparable to well-studied Mesozoic and Cenozoic examples. If our estimate of $\tau$ lies significantly outside the range of 50-65 m.y., it would falsify the thermal subsidence hypothesis.

Even though we do not know $E_{0} r$, estimation of $\tau$ and extrapolation of the curve back in time requires as few as two known elevation-time pairs, $\left(e_{1}, t_{1}\right)$ and $\left(e_{2}, t_{2}\right)$ (Fig. 17). Substituting these pairs into Equation 1, differencing the equations, and solving for $\tau$ yields:

$$
\tau=\frac{\left(t_{2}-t_{1}\right)}{\ln \left(\frac{e_{1}}{e_{2}}\right)} .
$$

The differencing of the two equations eliminates $E_{0} r$, and hence the most important parameters in estimating both $\tau$ and the thermal subsidence curve itself are the elevation of two points relatively well separated in time from each other, and an estimate of zero elevation, i.e., where $e(\infty)=0$ or the slope of $Y(t)$ is negligible. The thermal subsidence curve is then presumably applicable back in time to whatever point in the section at which we are still confident that the margin is in a state of pure thermal subsidence. As noted above, this level is probably no higher in the section than the lower part of the Johnnie Formation, and it may be much deeper, perhaps within the upper part of the underlying Pahrump Group.

Temporal constraints on the younger part of the subsidence curve are fairly similar to those used by Levy and Christie-Blick (1991), with the exception of their two oldest points, the base of the Cambrian Age 5 (approximately Middle Cambrian, $509 \mathrm{Ma}$; Walker et al., 2013) and the base of the Paibian (approximately Upper Cambrian, $497 \mathrm{Ma}$; Walker et al., 2013), which at the time were estimated to be $540 \mathrm{Ma}$ and $523 \mathrm{Ma}$, respectively. Critically for this study, both the position and age of the Ediacaran-Cambrian boundary are well defined lying within the Lower Member of the Wood Canyon Formation with an age of $541 \mathrm{Ma}$ (Corsetti and Hagadorn, 2000). The 541 and 509 Ma constraints thus function as points $\left(e_{1}, t_{1}\right)$ and $\left(e_{2}, t_{2}\right)$, respectively, in our initial analysis, defining an exponential subsidence curve. As the oldest reliable temporally constrained points on the curve, they are the strongest constraints on extrapolating the curve back in time.

Points younger than $509 \mathrm{Ma}$ are also well dated. These points clearly postdate the Sauk marine transgression, which marks a transition from predominantly siliciclastic to carbonate sedimentation, due to flooding of the craton through middle and late Cambrian time. Associated with the transgression, the average deposition rate $S(t)$ increases markedly from $\sim 20 \mathrm{~m} / \mathrm{m}$.y. from 541 to $509 \mathrm{Ma}$ to $\sim 80 \mathrm{~m} / \mathrm{m}$.y. from 509 to $497 \mathrm{Ma}$ (Table 4). Clearly, a fourfold increase in accumulation rate appears incompatible with any form of exponential subsidence. As explained below, the remarkable increase in subsidence rate owes its origin to the combination of sea-level rise and carbonate sedimentation, not renewed tectonism. The important point here is to note that the 541 and 509 Ma data points occur within the Lower Wood Canyon and Lower Carrara formations, respectively, both of which are shallow-water mixed carbonate-siliciclastic facies associations that were probably deposited at similar points in global sea level. Both were deposited during highstand intervals relative to their transgressive substrates (the Stirling E Member and Zabriskie Formation, respectively). In the case of the Lower Member of the Wood Canyon Formation, the system evolved into a glacial drawdown of sea level (Smith et al., 2016). In the case of the lower Carrara Formation, sea level kept rising to a level that generally exceeded that of Ediacaran-early Cambrian time (Palmer, 1981).

The late subsidence history is characterized by very slow accumulation in Silurian and Early Devonian time $(<3 \mathrm{~m} / \mathrm{m}$.y.; Table 4$)$, and hence the difference between Silurian and Devonian values of $Y$ compared to those at 541 and 509 Ma provides firm estimates of $e_{1}$ and $e_{2}$. We note that with these constraints, the precise values of time and elevation for Paibian through Upper Ordovician strata provide little additional constraint on the form of the exponential subsidence curve.

\section{Temporal Model}

We present a temporal model of both observed subsidence $S(t)$ (i.e., stratigraphic thickness) and tectonic subsidence $Y(t)$ using a novel mode of presentation that orthogonally projects $Y(t)$ and $t(S)$ onto a graph of the numerically determined function $Y(S)$ (Fig. 18). In this approach, $Y(S)$ is plotted in the upper-left corner, $Y(t)$ is plotted in the upper-right corner, $t(S)$ is plotted in the lower-left corner, and $S(t)$ is plotted in the lower-right corner. The plot shows a simultaneous projection of $Y$ and $S$ onto their respective temporal models graphically showing the influence of the slope of $Y(S)$ on the observed subsidence rates. The graph shows that, between 509 and $485 \mathrm{Ma}$, the increase in compressibility of the carbonate sediment [lower slope on $Y(S)$ ] combined with the accelerated schedule of subsidence caused by the flooding of the craton [higher slope on $Y(t)]$ resulted in a dramatic increase in sediment accumulation rate [lower slope on $t(S)$ and higher slope on $S(t)$ ], even though exponential thermal subsidence was slowly decreasing. This result is critical because it obviates the primary reason that most previous workers have cited in favor of Cambrian rifting along western Laurentia (e.g., Bond and Kominz, 1984; Levy and Christie-Blick, 1991; Yonkee et al., 2014).

\section{Parameter Estimates and Sensitivities}

Estimates of the exponential time constant $\tau$ vary according to two main uncertainties, (1) the sediment grain density assumed in our delithification model, and (2) whether or not a thick substrate of Pahrump Group strata is present at depth beneath the exposed Spring Mountains section. We calculated values 


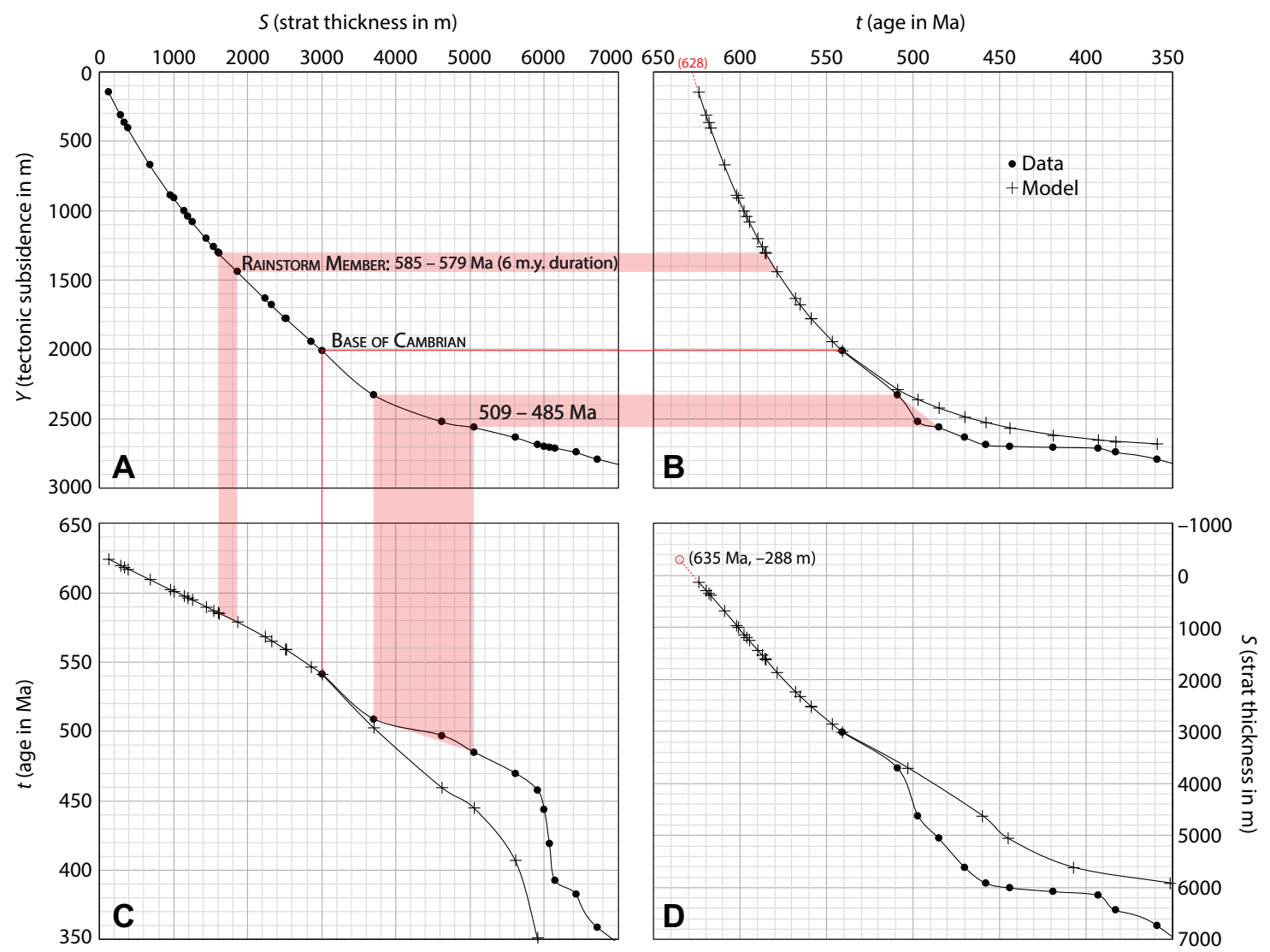

Figure 18. Plots showing subsidence data and model for northwest Spring Mountains section of southwest Laurentia (A) observed subsidence (stratigraphic (B) Cam che with plus symbols; (C) simis whing $s$ vs. $t$; and (D) sas a wowng $S$ vs. t; and (D) same as C but number in $B$ show projed a un ire in $D$ show the amount of addition cich bew unit $A$ in the Spring Mountains in order for $A$ in the Spring Mountains in back in time to $635 \mathrm{Ma}$.

of $\tau$ for values of tectonic subsidence $Y$ in a series of models that encompass these parameter variations (Table 5). In addition, we defined $Y$ according to two different assumptions for the point at which mechanical stretching ends and purely thermal subsidence begins, where $Y=0$ (i.e., $e=E_{0} r$ ). One is at the lowest exposed stratum (base of unit $A$ ), and the other is within unit $C$, above the youngest ball-and-pillow structure at the top of unit $B$, assuming seismic shaking ended near this point. In Table 5, models with no Pahrump Group substrate are designated $Y_{\mathrm{ns}}$, and those that include the substrate are designated $Y_{\text {wi }}$ intermediate-density models contain no additional subscript, and low- and high-density models are also subscripted "low" and "high," respectively. Models with "**" define $Y=0$ within unit $C$, and models with no superscript assume $Y=0$ at the base of unit A. We defined the value of $Y$ for which $e=0$ to be the average of $Y(393 \mathrm{Ma})$ and $Y(383 \mathrm{Ma})$, designated $Y(\mathrm{c} .388)$ in Table 5. The result are insensitive to this choice because there is so little variation in $Y$ between 444 and $383 \mathrm{Ma}$. We cannot choose the next younger point in the subsidence profile (359 Ma), because it clearly reflects the onset of subsidence associated with Antler foredeep sedimentation.

The contrast in $\tau$ between models $Y_{\text {ns }}$ and $Y_{\text {ws }}$ is only 3 m.y., with $\tau=55$ and 52 m.y., respectively. As expected from Equation 4, the definition point of $Y=0$ has no effect, because we define $e_{1}$ and $e_{2}$ on the basis of differences in $Y$ values late in the subsidence history. For models with no substrate, varying the density between $Y_{\mathrm{ns}}$ low and $Y_{\mathrm{ns}}$, high (corresponding to the assumption of high and low sediment grain density, respectively) has a substantial effect on $\tau$, which ranges from 42 to 65 m.y., respectively. For models $Y_{\text {ws, }}$ to $Y_{\text {ws, high, }}$ the sensitivity is even greater, with $\tau$ varying from 36 to 63 m.y., respectively. Clearly, the upper part of these ranges accords with subsidence patterns in Mesozoic and Cenozoic basins. Despite the nearly $30 \mathrm{~m} . \mathrm{y}$. variation in $\tau$ among these models, we note that there is relatively little variation in the modeled age and duration of the Shuram excursion (Table 5). Among this suite of models, the onset varies by $12 \mathrm{~m}$. (from 569 to $581 \mathrm{Ma}$ ), the 


\begin{tabular}{|c|c|c|c|c|c|c|c|c|}
\hline Model & $Y(541)$ & $Y(509)$ & $Y(393)$ & $Y(383)$ & $Y(\text { c. 388) })^{\S}$ & $\begin{array}{c}\tau \\
\text { (m.y.) }\end{array}$ & $\begin{array}{l}\text { SE begin" } \\
\text { (Ma) }\end{array}$ & $\begin{array}{l}\text { SE end" } \\
\text { (Ma) }\end{array}$ \\
\hline$Y_{\text {ns }}$ & 2009 & 2327 & 2713 & 2743 & 2728 & 55 & 578 & 573 \\
\hline$Y_{\mathrm{ns}}{ }^{* *}$ & 1646 & 1964 & 2350 & 2380 & 2365 & 55 & 578 & 573 \\
\hline$Y_{\text {ns, low }}$ & 1844 & 2125 & 2367 & 2380 & 2374 & 42 & 574 & 569 \\
\hline$Y_{\text {ns }}$ & 2009 & 2327 & 2713 & 2743 & 2728 & 55 & 578 & 573 \\
\hline$Y_{\text {ns, high }}$ & 2173 & 2528 & 3058 & 3105 & 3082 & 65 & 581 & 575 \\
\hline$Y_{\text {ns, high }}{ }^{* *}$ & 1791 & 2146 & 2676 & 2723 & 2700 & 65 & 581 & 575 \\
\hline$Y_{\mathrm{ws}, \text { low }}$ & 2475 & 2710 & 2871 & 2878 & 2875 & 36 & 569 & 566 \\
\hline$Y_{\text {ws }}$ & 2757 & 3029 & 3334 & 3358 & 3346 & 52 & 575 & 570 \\
\hline$Y_{\text {ws, high }}$ & 3037 & 3347 & 3795 & 3836 & 3816 & 63 & 578 & 573 \\
\hline
\end{tabular}

†Units for $\tau$ are millions of years (m.y.). Units for all $Y$ values are in meters $(m)$.

\$Mean value of $Y(393 \mathrm{Ma})$ and $Y(383 \mathrm{Ma})$

"SE-Shuram excursion.

(t) stratigraphic column inferred to represent cessation of mechanical stretching and inception of passive-margin thermal subsidence.

termination varies by 9 m.y. (from 566 to $575 \mathrm{Ma}$ ), and the duration varies by 3 m.y. (from 3 to 6 m.y.).

A further consideration in estimating $\tau$ is the fact that because the Sauk transgression was well under way by $509 \mathrm{Ma}$, relative sea level may have been slightly higher than at $541 \mathrm{Ma}$. To the extent that it was, a significant systematic error is introduced in our estimate of $\tau$. For example, for the model with no substrate and intermediate density, a correction in $Y(509)$ of just $-50 \mathrm{~m}$ to account for a change in sea level $\left(+50 \mathrm{~m}\right.$ in $\left.e_{2}\right)$ changes the estimate of $\tau$ from 55 to 69 m.y. (Eq. 1 in Steckler and Watts, 1978; Eq. 4 herein). Thus, although the suite of models used for our sensitivity analysis may suggest an estimate of $50 \pm \sim 15$ m.y. for $\tau$, the systematic error introduced by the Sauk transgression, and the range of values indicated by models of Mesozoic and Cenozoic basins both suggest a value toward the upper end of this range. We further note that the earliest empirical fits to long-term seafloor subsidence data sug gested a value of 62.8 m.y. (Eq. 22 in Parsons and Sclater, 1977; table 1 in McKenzie, 1978).

Based on these considerations, we developed a second suite of models for estimating pre-541 Ma ages of various horizons within the Johnnie Formation. For this suite, we chose a "midrange" model using what are perhaps the simplest set of assumptions: (1) intermediate sediment grain density values; (2) negligible Pahrump Group substrate; and (3) a time constant of $\tau=65$ m.y. Using these assumptions, we tied the subsidence curve to the oldest dated point at $541 \mathrm{Ma}$, minimizing both the amount of extrapolation back in time and the degree to which the data reflect sea-level rise due to the Sauk and subsequent cratonic flooding events. The resulting subsidence model for the Spring Mountains section is shown in Figure 18 and in Table 6 in the second column from the right-hand side. The remaining columns in Table 6 and Table S2 (footnote 1) demonstrate the sensitivity of our resulting age estimates for the Shuram excursion and other horizons in the Johnnie and Stirling formations to variations in density, $\tau$, and the presence or absence of a substrate. Varying only sediment grain density, limits on the Shuram excursion (tops of units Zjr1 to Zjr2) are 581-575 Ma (low-density case), 585-579 Ma (intermediate density), and 592-585 Ma (high density; Fig. S4 [footnote 1]). Thus, we see that the end of the Shuram excursion varies from 575 to $585 \mathrm{Ma}$, a range that is centered on the timing of the Gaskiers glaciation. We also note that the duration of the excursion is 6-7 m.y., and it is therefore insensitive to variations in sediment grain density. With regard to sensitivity to the time constant, the end of the Shuram excursion for intermediate density values is 579,576 , and $573 \mathrm{Ma}$ for $\tau=65,60$, and 55 m.y., respectively (Fig. S5 [footnote 1]). In terms of the error introduced by the presence of a Pahrump Group substrate (Fig. S6; Table S2 [footnote 1]), for $\tau=65$ m.y. and intermediate values of density, the Shuram excursion occurs from 584 to $578 \mathrm{Ma}$, which is only $1 \mathrm{~m} . \mathrm{y}$. later than, and of the same duration as, the case of no substrate. The duration of the Shuram excursion across all models in this suite ranges from 4 to 7 m.y. If we exclude with-substrate models (Table S2 [footnote 1]), the variation decreases to 5-7 m.y., and if we further restrict the time constant to $65 \mathrm{~m} . y$. , it decreases to 6-7 m.y. These estimates are consistent with recent estimates of 8-9 m.y. for the Johnnie Formation, South Australia (Wonoka), and central China (Doushantuo) sections, based on rock magnetic chronostratigraphy (Minguez et al., 2015; Minguez and Kodama, 2017; Gong et al., 2017). These estimates are all considerably shorter than the subsidence-based estimate of 50 m.y. for the Shuram excursion in Oman (Le Guerroué et al., 2006b), which has been called 
TABLE 6. ALL AGES MODELED USING NO SUBSTRATE

\begin{tabular}{|c|c|c|c|c|c|c|c|c|c|c|}
\hline \multirow[b]{3}{*}{ Unit } & \multirow{3}{*}{$\begin{array}{l}\mathrm{Age}^{\dagger} \\
(\mathrm{Ma})\end{array}$} & \multicolumn{9}{|c|}{ Model ages (Ma) } \\
\hline & & \multicolumn{3}{|c|}{$\tau=55$ m.y. } & \multicolumn{3}{|c|}{$\tau=60$ m.y. } & \multicolumn{3}{|c|}{$\tau=65$ m.y. } \\
\hline & & Min & Int & $\operatorname{Max}$ & Min & Int & $\operatorname{Max}$ & Min & Int & $\operatorname{Max}$ \\
\hline MzPzco & Ca. 243 & - & - & - & - & - & - & - & - & - \\
\hline Ddg & 359 & - & - & - & - & - & - & - & - & - \\
\hline Dn & 383 & - & - & - & - & - & - & - & - & - \\
\hline DI & 393 & 341 & 328 & 303 & 323 & 309 & 281 & 305 & 289 & 260 \\
\hline SI & 419 & 363 & 349 & 323 & 347 & 332 & 303 & 331 & 314 & 283 \\
\hline Oes & 444 & 378 & 364 & 337 & 363 & 348 & 319 & 348 & 332 & 300 \\
\hline $\mathrm{Oe}$ & 458 & 393 & 381 & 352 & 380 & 366 & 335 & 366 & 352 & 317 \\
\hline Op1 & 470 & 435 & 428 & 415 & 425 & 418 & 404 & 416 & 407 & 393 \\
\hline O€n1 & 485 & 467 & 460 & 446 & 460 & 452 & 437 & 453 & 445 & 429 \\
\hline €bk1 & 497 & 481 & 472 & 455 & 475 & 466 & 447 & 470 & 460 & 439 \\
\hline$€ c 1$ & 509 & 514 & 509 & 499 & 511 & 506 & 496 & 509 & 503 & 492 \\
\hline EZwc1 & 541 & 541 & 541 & 541 & 541 & 541 & 541 & 541 & 541 & 541 \\
\hline Zse & - & 545 & 546 & 547 & 546 & 546 & 547 & 546 & 547 & 548 \\
\hline Zsd & - & 555 & 556 & 559 & 556 & 558 & 560 & 557 & 559 & 562 \\
\hline Zsc & - & 555 & 556 & 559 & 556 & 558 & 561 & 557 & 559 & 562 \\
\hline Zsb & - & 560 & 562 & 565 & 561 & 563 & 567 & 563 & 565 & 569 \\
\hline Zsa & - & 562 & 564 & 568 & 564 & 566 & 570 & 565 & 568 & 573 \\
\hline Zjr2 & - & 570 & 573 & 578 & 573 & 576 & 581 & 575 & 579 & 585 \\
\hline Zjr1 & - & 575 & 578 & 584 & 578 & 582 & 588 & 581 & 585 & 592 \\
\hline Zjl & - & 575 & 579 & 584 & 578 & 582 & 588 & 581 & 586 & 592 \\
\hline Zjk & - & 576 & 580 & 586 & 580 & 584 & 590 & 583 & 587 & 594 \\
\hline Zjj & - & 579 & 582 & 588 & 582 & 586 & 592 & 585 & 590 & 597 \\
\hline Zji & - & 582 & 587 & 593 & 586 & 591 & 598 & 590 & 595 & 602 \\
\hline Zjh & - & 584 & 588 & 594 & 587 & 592 & 599 & 591 & 596 & 604 \\
\hline Zjg & - & 585 & 589 & 596 & 589 & 593 & 601 & 593 & 598 & 606 \\
\hline Zjf & - & 588 & 592 & 599 & 592 & 597 & 604 & 596 & 601 & 610 \\
\hline Zje & - & 588 & 593 & 600 & 592 & 597 & 605 & 597 & 602 & 610 \\
\hline Zjd & - & 594 & 599 & 606 & 599 & 604 & 612 & 603 & 609 & 618 \\
\hline Zjc2 & - & 600 & 605 & 614 & 605 & 611 & 620 & 611 & 617 & 627 \\
\hline Zjc1 & - & 601 & 606 & 615 & 606 & 612 & 622 & 612 & 618 & 628 \\
\hline Zjb & - & 602 & 608 & 616 & 607 & 614 & 623 & 613 & 620 & 630 \\
\hline Zja & - & 605 & 611 & 620 & 611 & 618 & 627 & 617 & 624 & 635 \\
\hline (base) & - & 608 & 614 & 623 & 614 & 621 & 631 & 620 & 628 & 639 \\
\hline
\end{tabular}

${ }^{\dagger}$ Ages are at top of unit.

into question on the basis that the Khufai/Shuram interval was probably not deposited on a thermally subsiding continental shelf (Bowring et al., 2007).

In sum, because the timing of the Shuram excursion is within $\sim 0.5 \tau$ of $541 \mathrm{Ma}$, varying parameters in the exponential subsidence model yields variations in our estimate of age and duration of the Shuram excursion of just a few million years. The fact that a fairly broad range of parameters leads to estimates of the end of the Shuram excursion centered on $579 \mathrm{Ma}$ suggests that the valleys incised into the Rainstorm Member are indeed a manifestation of the Gaskiers glaciation at equatorial latitudes. To conclude otherwise strains credulity, because Johnnie/Stirling sequence architecture is relatively uneventful for 400-500 m both above and below the Rainstorm Member (Stirling Member A/B and Johnnie units $H$ through $L$, respectively). If incision was unrelated to the Gaskiers glaciation, this requires: (1) that the most dramatic stratigraphic event in the Johnnie/Stirling interval was close in time, but unrelated to, glaciation and (2) that the Gaskiers glaciation itself had virtually no impact on the section. In essence, the subsidence analysis provides a relatively coarse estimate of age that "registers" the section with possible correlatives elsewhere. The detailed stratigraphy then fine tunes the age estimate based on a specific correlation with well-dated events elsewhere, in this case, shelf-incision and the Gaskiers glaciation.

The overall consistency of exponential subsidence models with the hypothesis that incision of the Rainstorm Member shelf is an expression of 
the Gaskiers glaciation suggests that modeled ages of other horizons in the Johnnie/Stirling interval may also be accurate to within a few million years. The overall accuracy of this model can be further tested by assessing how well it estimates the age of the lowermost Johnnie and Noonday interval. As noted above in our discussion of the possible correlation of unit $A$ with the Noonday Formation, we would expect the age of this unit to be close to the age of the base of the Noonday Formation, or $635 \mathrm{Ma}$ (Petterson et al., 2011). The ranges of modeled ages for the base of unit $A$ are 639-608 Ma (Table 6), with the "midrange" model shown in Figure 18B predicting an age of $628 \mathrm{Ma}$ As shown in Figure 18D, linear extrapolation below the deepest exposed strata of unit $A$, assuming a linear deposition rate, would require only an additional $288 \mathrm{~m}$ of "subunit A" strata to bring the section to the base of the Noonday Formation and the Ediacaran Period. This thickness plus the $125 \mathrm{~m}$ thickness of unit $A$ yields a total thickness of $413 \mathrm{~m}$, which is consistent with maximum known thicknesses of the Noonday Formation (Petterson et al., 2011). The ap parent success of exponential subsidence models in predicting the age of both the Gaskiers event and the base of the Ediacaran Period at their most likely stratigraphic levels supports the hypothesis that Ediacaran deposition on the southwest Laurentian margin was largely continuous, and that the Noonday through Wood Canyon interval in its thickest, most basinal exposures does not contain unconformities with significant depositional hiatuses.

\section{CONCLUSIONS}

Lithostratigraphic and chemostratigraphic details of the Johnnie Formation at its type locality in the northwest Spring Mountains of southern Nevada provide a basis for regional lithostratigraphic correlation, global chemostratigraphic correlation, and subsidence analysis of the southwest Laurentian continental margin. The regional lithostratigraphy of Ediacaran through Cambrian Age 4 strata defines seven sand-rich intervals separated by siltstone- and carbonaterich intervals, the upper two of which are the Sauk I and Sauk II sequences of Cambrian age (Palmer, 1981). The great overall thickness of the Johnnie Formation at its type locality $(\sim 1800 \mathrm{~m})$, and the apparent absence of subaerial exposure surfaces or other evidence of erosion that are well expressed in more cratonic sections, such as the Nopah Range section, support the hypothesis of continuous deposition. Nonetheless, the lithostratigraphy is strongly cyclic at the kilometer scale, suggesting that significant hiatuses, or at least greatly reduced rates of sediment flux, may be associated with the base of each of the seven sand-rich intervals, even in the more basinal sections. We therefore caution that the true slope of the observed sediment accumulation curve $S(t)$ is almost certainly more variable than that shown in Figure 18D, especially for the segment between $635 \mathrm{Ma}$ and $541 \mathrm{Ma}$. This concern is tempered by the fact that sediment flux was sufficient in Ediacaran and Paleozoic time to fill the accommodation space to within a few meters to a few tens of meters of sea level, implying that the tectonic component of subsidence was fully recorded.

Carbon isotopic data from sub-Rainstorm Member (sub-Shuram excursion) units in the Mount Schader section are generally positive and support correlation of Johnnie Formation units $\mathrm{H}$ through $\mathrm{L}$ with the Khufai Formation in Oman, but they do not require it. If correlative, the Mount Schader section would provide the first confirmation of an extended period (represented by $300-400 \mathrm{~m}$ of section) of positive $\delta^{13} \mathrm{C}$ values prior to the Shuram excursion in both Oman and Nevada.

The Gaskiers glaciation marks the beginning of widespread preservation of macroscopic Ediacaran animals (Xiao et al., 2016), and the Shuram excursion is the largest known carbon isotopic excursion in the geological record. A central issue in animal evolution is thus whether or not the Shuram excursion was approximately synchronous with the Gaskiers event, because it suggests that the Shuram excursion, whatever its cause, was genetically related to creating a surface environment that could support the metabolic requirements of macroscopic animals. A second consequence of Shuram-Gaskiers correlation is that it places the transition from diverse, ornamented acritarchs to a lower-diversity, unornamented assemblage in synchronism with the appearance of macroscopic animals, rather than at some later time. The issue is addressable in southwest Laurentia, to the extent that deposition of Johnnie Formation and related strata occurred more-or-less continuously on a thermally subsiding passive margin.

Based on this assumption, subsidence analysis strongly suggests that the end of Johnnie Formation deposition, at the time of valley incision and subsequent fill with the conglomeratic member, was correlative with the Gaskiers glaciation at $579 \mathrm{Ma}$. The analysis also suggests that the onset of the Shuram excursion near the base of the Rainstorm Member occurred at ca. $585 \mathrm{Ma}$. The implied 6 m.y. duration of the Shuram excursion is consistent with paleomagnetic and other proxies from sections in Laurentia and Australia. The subsidence analysis further indicates that if the assignment of the Gaskiers event to uppermost Johnnie time is correct, then the base of the Johnnie Formation is ca. $630 \mathrm{Ma}$. If so, then the Johnnie through lower Wood Canyon interval in the Spring Mountains represents a relatively complete, 3000-m-thick section that records most or all of Ediacaran time.

\section{ACKNOWLEDGMENTS}

We are grateful to Gillian Anderson, Leah Sabbeth, Fenfang $\mathrm{Wu}$, and the late Lindsey Hedges for assistance in the field and laboratory, and to Associate Editor Christopher J. Spencer and reviewer Tony Prave for insightful and constructive reviews. This material is based upon work supported by the National Science Foundation Graduate Research Fellowship Program under grant 1144469 awarded to R. Witkosky, and grant EAR 14-51055 awarded to B. Wernicke.

\section{APPENDIX. DESCRIPTION OF MAP UNITS}

Descriptions apply to geologic maps and stratigraphic columns shown in Figures 3, 4, 6, and Qa: Alluvium and colluvium in active/ephemeral channels and piedmont-forming slopes. QTI: In Johnnie Wash, a topographically prominent ridge of coarse, poorly sorted debris, here interpreted as a landslide deposit.

Zsa: Stirling Formation, A Member (labeled "Zs" on maps). Very pale-orange, grayish-blackweathering, medium-grained orthoquartzite, laminated to massive, medium to thick bedded, with trough cross-stratification. Contains some interbedded carbonate-cemented sandstone. In places bedding is destroyed by secondary brecciation and recementation, forming irregular dark-weathering masses. Unit forms resistant ridges relative to underlying Johnnie Formation. 
Zjr: Johnnie Formation, Rainstorm Member. Includes four distinct subunits, from bottom to top: (1) green phyllitic siltstone, (2) highly resistant, ocher-colored oolitic dolostone ("Johnnie oolite, indicated by red open-dotted line, $2 \mathrm{~m}$ thick), (3) pale-red, carbonate-cemented, fine-grained sandstone and sandy limestone, and (4) a heterogeneous upper unit that includes siltstone, carbonate-rich sandstone, flaser-bedded sandy carbonate, and intraformational limestone breccia. In the Mount Schader section, an $\sim 4$-m-thick triad of orthoquartzite, siltstone, and dolostone immediately underlies the Stirling Formation. Orthoquartzite is affected by meter-scale ball-and-pillow structure. Zj: Orthoquartzite and variegated siltstone. Generally a recessive/slope-forming unit. Red dotted line on Mount Schader map indicates a resistant, laminated, brown dolomitic marker bed,
$\sim 2 \mathrm{~m}$ thick.

Zjk: Orthoquartzite, variegated siltstone, and dolostone. Orthoquartzite is parallel bedded and forms erosionally resistant base; siltstone locally contains ripple laminations; resistant, brown dolomitic marker bed, indicated by red dotted line in Mount Schader map area, is hummocky cross-stratified and contains chert in its lower portion.

Zjj: Orthoquartzite, variegated siltstone, and minor dolomitic sandstone. Orthoquartzite and siltstone occur in $\sim 5 \mathrm{~m}$ cycles. Orthoquartzite is white, resistant, and locally granular, and it con tains high-angle $\left(\sim 20^{\circ}\right)$ cross-stratification; dolomitic sandstones are thick, brown, resistant, fineto medium-grained beds. Red dotted line on both maps indicates a hummocky cross-stratified brown dolomite marker bed.

Zji: Orthoquartzite, variegated siltstone, and dolomitic sandstone, parallel bedded in the Johnnie Wash section, and hummocky cross-stratified in the Mount Schader section. Orthoquartzite is fine-grained and occurs as conspicuous thick-bedded intervals in 5-10 $\mathrm{m}$ cycles with siltstones. Red dotted line on Mount Schader map indicates a hummocky cross-stratified, brown dolomitic sandstone marker bed.

Zjh: Orthoquartzite and variegated siltstone. Red dotted lines on Mount Schader map indicat brown, hummocky cross-stratified dolomite marker beds that contain stromatolitic mounds.

Zjg: Variegated fine-grained sandstone and siltstone, weakly cemented; also occasional interstratified orthoquartzite, fine to medium grained, medium to thick bedded.

Zjf: Dolostone with centimeter- to decimeter-thick, centimeter- to meter-long chert nodules and lenses. The dolostone forms a conspicuous pale-weathering ridge. It is finely laminated to massive. Microcrystalline varieties weather gray; coarser-grained, secondary dolomite weather dark gray to brown.

Zje: Massive, fine-grained sandstone and laminated siltstone. Upper part contains severa dozen rhythmic cycles, $\sim 2 \mathrm{~m}$ thick, of sandstone and siltstone. Each cycle has a sharp, load-caste bottom and grades upward from sandstone to siltstone. Generally an olive-hued, recessive slope-forming unit, with occasional beds of cross-stratified sandstone, similar to unit $D$.

Zjd: Well-cemented, fine-grained orthoquartzite in meter-scale beds featuring cross-stratification with steep truncation angles (up to $\sim 30^{\circ}$ ), interstratified with medium-grained, weakly hematite-cemented ferruginous sandstone and variegated siltstone. Unit forms resistant ridge that is conspicuously darker weathering than unit $\mathrm{E}$.

Zjc: Siltstone (as Zja) with a calcareous, medium-grained orthoquartzite marker bed, simila to unit $D$, indicated on Figure 3 by green dotted line. The lowest carbonate in the Johnnie Wash section appears near the top of this unit as a brown, medium-grained, fabric-retentive dolostone. Zjb: Interstratified fine-grained orthoquartzite and phyllitic siltstone. Orthoquartzite occurs in
meter-scale beds with parallel lamination, pervasively disrupted by soft sediment deformation, meter-scale beds with parallel lamination, pervasively disrupted by soft sediment deformation,
primarily ball-and-pillow structure, such that individual beds are difficult to trace along strike. primarily ball-and-pillow structure, such that individual beds are difficult to trace along strike.
Zja: Phyllitic siltstone, with a distinct crenulation cleavage at high angle to bedding, generally Zja: Phyllitic
a recessive unit.

\section{REFERENCES CITED}

Abolins, M.J., 1999, I. Stratigraphic Constraints on the Number of Discrete Neoproterozoic Glaciations and the Relationship between Glaciation and Ediacaran Evolution; II. The Kwichup Spring Thrust in the Northwest Spring Mountains, Nevada: Implications for Large-Magnitude Extension and the Structure of the Cordilleran Thrust Belt [Ph.D. thesis]: Pasadena, California, California Institute of Technology, $341 \mathrm{p}$.

Abolins, M., Oskin, R., Prave, T., Summa, C., and Corsetti, F, 2000, Neoproterozoic glacial record in the Death Valley region, California and Nevada, in Lageson, D.R., Peters, S.G., and Lahren, M.M., eds., Great Basin and Sierra Nevada: Geological Society of America Field Guide 2, p. 319-335, https://doi.org/10.1130/0-8137-0002-7.319.
Albee, A.L, Labotka, TC, Lanphere, M.A, and McDowell, S.D., 1981, Geologic Map of the Telescope Peak Quadrangle, California: U.S. Geological Survey Geological Quadrangle Map GQ-1532, scale 1:62,500, 1 sheet.

faro, P., Delgado, J., Estévez, A., Molina, J.M., Moretti, M., and Soria, J.M., 2002, Liquefaction and fluidization structures in Messinian storm deposits (Bajo Segura Basin, Betic Cordillera, southern Spain): International Journal of Earth Sciences, v. 91, p. 505-513, https://doi.org/10 .1007/s00531-001-0241-z.

Alan, J.R., and Matthews, R.K., 1977, Carbon and oxygen isotopes as diagenetic and stratigraphic tools: Surface and subsurface data, Barbados, West Indies: Geology, v. 5, p. 16-20, https://doi.org/10.1130/0091-7613(1977)5<16:CAOIAD>2.0.CO;2.

Allan, J.R., and Matthews, R.K., 1982, Isotope signatures associated with early meteoric diagenesis: Sedimentology, v. 29, p. 797-817, https://doi.org/10.1111/j.1365-3091.1982.tb00085.x. Allen, P.A., and Allen, J.R., 2005, Basin Analysis: Principles and Applications (second edition): Malden, Massachusetts, Blackwell Publishing, $549 \mathrm{p}$.

Allmendinger, R.W., Cardozo, N., and Fisher, D., 2012, Structural Geology Algorithms: Vector and Tensors in Structural Geology: Cambridge, UK, Cambridge University Press, $302 \mathrm{p}$.

Armin, R.A., and Mayer, L., 1983, Subsidence analysis of the Cordilleran miogeocline: Implications for timing of late Proterozoic rifting and amount of extension: Geology, v. 11, p. 702 705, https://doi.org/10.1130/0091-7613(1983)11<702:SAOTCM>2.0.CO;2.

Bekker, A., and Holland, H.D., 2012, Oxygen overshoot and recovery during the early Paleoproterozoic: Earth and Planetary Science Letters, v. 317-318, p. 295-304, https://doi.org/10 .1016/j.epsl.2011.12.012

Benmore, W.C., 1978, Stratigraphy, Sedimentology, and Paleoecology of the Late Paleophytic or Earliest Phanerozoic Johnnie Formation, Eastern California and Southwestern Nevada [Ph.D. thesis]: Santa Barbara, California, University of California, $243 \mathrm{p}$.

Bergmann, K.D., Zentmyer, R.A., and Fischer, W.W., 2011, The stratigraphic expression of a large negative carbon isotope excursion from the Ediacaran Johnnie Formation, Death Valley: Precambrian Research, v. 188, p. 45-56, https://doi.org/10.1016/j.precamres.2011.03.014.

Boggs, S., Jr., 2012, Principles of Sedimentology and Stratigraphy (5th ed.): Englewood Cliffs, New Jersey, Pearson Prentice Hall, $585 \mathrm{p}$.

Bond, G.C., and Kominz, M.A., 1984, Construction of tectonic subsidence curves for the early Paleozoic miogeocline, southern Canadian Rocky Mountains: Implications for subsidence mechanisms, age of breakup, and crustal thinning: Geological Society of America Bulletin, v. 95, no. 2, p. 155-173, https://doi.org/10.1130/0016-7606(1984)95<155:COTSCF>2.0.CO;2.

Bond, G.C., Kominz, M.A., and Devlin, W.J., 1983, Thermal subsidence and eustasy in the Lower Palaeozoic miogeocline of western North America: Nature, v. 306, no. 5945, p. 775-779, https://doi.org/10.1038/306775a0.

Bond, G.C., Kominz, M.A., and Grotzinger, J.P., 1988, Cambro-Ordovician eustasy: Evidence from geophysical modelling of subsidence in Cordilleran and Appalachian passive ma gins, in Kleinspehn, K.L., and Paola, C., eds., New Perspectives in Basin Analysis: New York, Springer, p. 129-160, https://doi.org/10.1007/978-1-4612-3788-4_7.

Bowring, S., Myrow, P., Landing, E., Ramezani, J., Condon, D., and Hoffmann, K.H., 2003a, Geochronological constraints on Neoproterozoic glaciations and the rise of metazoans: Geological Society of America Abstracts with Programs, v. 35, no. 6, p. 516

Bowring, S.A., Myrow, P.M., Landing, E., and Ramezani, J., 2003b, Geochronological constraints on terminal Neoproterozoic events and the rise of metazoans: Geophysical Research Abstracts, v. 5 , no. 13219, p. 219

Bowring, S.A., Grotzinger, J.P., Condon, D.J., Ramezani, J., Newall, M.J., and Allen, P.A., 2007, Geochronologic constraints on the chronostratigraphic framework of the Neoproterozoic Huqf Supergroup, Sultanate of Oman: American Journal of Science, v. 307, p. 1097-1145, https://doi.org/10.2475/10.2007.01.

Burchfiel, B.C., 1964, Precambrian and Paleozoic stratigraphy of Specter Range quadrangle, Nye County, Nevada: American Association of Petroleum Geologists Bulletin, v. 48, no. 1, p. 40-56. Burchfiel, B.C., 1965, Structural geology of the Specter Range quadrangle, Nevada, and its regional significance: Geological Society of America Bulletin, v. 76, no. 2, p. 175-192, https:// doi.org/10.1130/0016-7606(1965)76[175:SGOTSR]2.0.CO;2.

Burchfiel, B.C., and Davis, G.A., 1972, Structural framework and evolution of the southern part of the Cordilleran orogen, western United States: American Journal of Science, v. 272, no. 2 p. 97-118, https://doi.org/10.2475/ajs.272.2.97.

Burchfiel, B.C., and Davis, G.A., 1975, Nature and controls of Cordilleran orogenesis, western United States: Extensions of an earlier synthesis: American Journal of Science, v. 275-A, p. 363-396. 
Burchfiel, B.C., Fleck, R.J., Secor, D.T., Vincelette, R.R., and Davis, G.A., 1974, Geology of the Spring Mountains, Nevada: Geological Society of America Bulletin, v. 85, p. 1013-1022, https://doi.org/10.1130/0016-7606(1974)85<1013:GOTSMN>2.0.CO;2.

Burchfiel, B.C., Hamill, G.S., IV, and Wilhelms, D.E., 1983, Structural geology of the Montgomery Mountains and the northern half of the Nopah and Resting Spring Ranges, Nevada and California: Geological Society of America Bulletin, v. 94, p. 1359-1376, https://doi.org/10.1130 10016-7606(1983)94<1359:SGOTMM>2.0.CO;2.

Burns, S.J., and Matter, A., 1993, Carbon isotopic record of the latest Proterozoic from Oman Eclogae Geologicae Helvetiae, v. 86, no. 2, p. 595-607.

Butterfield, N.J., 2009, Oxygen, animals, and oceanic ventilation: An alternative view: Geobiology, v. 7, p. 1-7, https://doi.org/10.1111/j.1472-4669.2009.00188.x.

Calver, C.R., 2000, Isotope stratigraphy of the Ediacaran (Neoproterozoic III) of the Adelaide Rift Complex, Australia, and the overprint of water column stratification: Precambrian Research, v. 100, p. 121-150, https://doi.org/10.1016/S0301-9268(99)00072-8.

Canfield, D.E., Poulton, S.W., and Narbonne, G.M., 2007, Late Neoproterozoic deep-ocean oxy genation and the rise of animal life: Science, v. 315, no. 5808, p. 92-95, https://doi.org/10 $.1126 /$ science. 1135013 .

Cardozo, N., 2009, Backstrip: http://www.ux.uis.no/ nestor/work/programs.html (accessed August 2017).

Cardozo, N., and Allmendinger, R.W., 2013, Spherical projections with OSXStereonet: Computers \& Geosciences, v. 51, p. 193-205, https://doi.org/10.1016/j.cageo.2012.07.021.

Clapham, M.E., and Corsetti, F.A., 2005, Deep valley incision in the terminal Neoproterozoic (Ediacaran) Johnnie Formation, eastern California, USA: Tectonically or glacially driven? Precambrian Research, v. 141, p. 154-164, https://doi.org/10.1016/j.precamres.2005.09.002. Cohen, P.A., Bradley, A., Knoll, A.H., Grotzinger, J.P., Jensen, S., Abelson, J., Hand, K., Love, G.,
Metz, J., McLoughlin, N., Meister, P., Shepard, R., Tice, M., and Wilson, J.P., 2009, Tubular compression fossils from the Ediacaran Nama Group, Namibia: Journal of Paleontology, v. 83, p. 110-122, https://doi.org/10.1017/S0022336000058169.

Condon, D., Zhu, M., Bowring, S., Wang, W., Yang, A., and Jin, Y., 2005, U-Pb ages from the Neoproterozoic Doushantuo Formation, China: Science, v. 308, p. 95-98, https://doi.org/10 $.1126 /$ science. 1107765

Corsetti, F.A., and Hagadorn, J.W., 2000, Precambrian-Cambrian transition: Death Valley, United States: Geology, v. 28, no. 4, p. 299-302, https://doi.org/10.1130/0091-7613(2000)28<299 PTDVUS $>2.0 . \mathrm{CO} ; 2$.

Corsetti, F.A., and Kaufman, A.J., 2003, Stratigraphic investigations of carbon isotope anomalies and Neoproterozoic ice ages in Death Valley, California: Geological Society of America Bulletin, v. 115, no. 8, p. 916-932, https://doi.org/10.1130/B25066.1.

Corsetti, F.A., Awramik, S.M., Pierce, D., and Kaufman, A.J., 2000, Using chemostratigraphy to correlate and calibrate unconformities in Neoproterozoic strata from the southern Grea Basin of the United States: International Geology Review, v. 42, p. 516-533, https://doi.org $10.1080 / 00206810009465096$.

Deer, W.A., Howie, R.A., and Zussman, J., 1992, An Introduction to the Rock-Forming Minerals (2nd ed.): London, UK, Pearson Education Limited, $696 \mathrm{p}$

Derry, L.A., 2010a, A burial diagenesis origin for the Ediacaran Shuram-Wonoka carbon isotop anomaly: Earth and Planetary Science Letters, v. 294, no. 1-2, p. 152-162, https://doi.org/10 .1016/j.epsl.2010.03.022.

Derry, L.A., 2010b, On the significance of $\delta^{13} \mathrm{C}$ correlations in ancient sediments: Earth and Planetary Science Letters, v. 296, p. 497-501, https://doi.org/10.1016/j.epsl.2010.05.035.

Dickinson, W.R., 1977, Paleozoic plate tectonics and the evolution of the Cordilleran continental margin, in Stewart, J.H., Stevens, C.H., and Fritsche, A.E., eds., Paleozoic Paleogeography of the Western United States: Los Angeles, California, Pacific Section, Society of Economic Paleontologists and Mineralogists (SEPM), Pacific Coast Paleogeography Symposium 1, p. 137-156.

Fedo, C.M., and Cooper, J.D., 2001, Sedimentology and sequence stratigraphy of Neoproterozoic and Cambrian units across a craton-margin hinge zone, southeastern California, and implications for the early evolution of the Cordilleran margin: Sedimentary Geology, v. 141-142, p. 501-522, https://doi.org/10.1016/S0037-0738(01)00088-4.

Field, C.B., Behrenfeld, M.J., Randerson, J.T., and Falkowski, P., 1998, Primary production of the biosphere: Integrating terrestrial and oceanic components: Science, v. 281, p. 237-240, https://doi.org/10.1126/science.281.5374.237.

Fike, D.A, Grotzinger, J.P., Pratt, L.M., and Summons, R.E, 2006, Oxidation of the Ediacaran ocean: Nature, v. 444, p. 744-747, https://doi.org/10.1038/nature05345.
Gabrielse, H., 1972, Younger Precambrian of the Canadian Cordillera: American Journal of Science, v. 272, no. 6, p. 521-536, https://doi.org/10.2475/ajs.272.6.521.

Giallorenzo, M.A., Wells, M.L., Yonkee, W.A., Stockli, D.F., and Wernicke, B.P., 2017, Timing of exhumation, Wheeler Pass thrust sheet, southern Nevada and California: Late Jurassic to middle Cretaceous evolution of the southern Sevier fold-and-thrust belt: Geological Society of America Bulletin, v. 130, no. 3-4, p. 558-579, https://doi.org/10.1130/B31777.

Gillett, S.L., and Van Alstine, D.R., 1982, Remagnetization and tectonic rotation of Upper Precambrian and Lower Paleozoic strata from the Desert Range, southern Nevada: Journal of Geophysical Research, v. 87, no. B13, p. 10,929-10,953, https://doi.org/10.1029/JB087iB13p10929.

Gong, Z., Kodama, K.P., and Li, Y.-X., 2017, Rock magnetic cyclostratigraphy of the Doushantuo Formation, South China, and its implications for the duration of the Shuram carbon isotope excursion: Precambrian Research, v. 289, p. 62-74, https://doi.org/10.1016/j.precamres.2016 .12 .002

Gotzinger, J.P., Fike, D.A., and Fischer, W.W., 2011, Enigmatic origin of the largest-known carbon isotope excursion in Earth's history: Nature Geoscience, v. 4, no. 5, p. 285-292, https://do .org/10.1038/ngeo 1138 .

Hagadorn, J.W., and Waggoner, B., 2000, Ediacaran fossils from the southwestern Great Basin, United States: Journal of Paleontology, v. 74, no. 2, p. 349-359, https://doi.org/10.1017 S0022336000031553.

Halley, R.B., and Schmoker, J.W., 1983, High-porosity Cenozoic carbonate rocks of south Florida: Progressive loss of porosity with depth: American Association of Petroleum Geologists Bulletin, v. 67, no. 2, p. 191-200.

Halverson, G.P., Hoffman, P.F, Schrag, D.P., Maloof, A.C., and Rice, A.H.N., 2005, Toward a Neoproterozoic composite carbon-isotope record: Geological Society of America Bulletin, v. 117, no. 9/10, p. 1181-1207, https://doi.org/10.1130/B25630.

Halverson, G.P., Wade, B.P., Hurtgen, M.T., and Barovich, K.M., 2010, Neoproterozoic chemostratigraphy: Precambrian Research, v. 182, p. 337-350, https://doi.org/10.1016/j.precamres.2010 04.007

Hamill, G.S., IV, 1966, Structure and Stratigraphy of the Mt. Shader Quadrangle, Nye County, Nevada-Inyo County, California [Ph.D. thesis]: Houston, Texas, Rice University, 83 p.

azzard, J.C., 1937, Paleozoic section in the Nopah and Resting Springs Mountains, Inyo County, California: California Journal of Mines and Geology, v. 33, no. 4, p. 273-339.

Caman, L.M., and Grotzinger, J.P., 1992, 1.08 Ga diabase sills in the Pahrump Group, California: Implications for development of the Cordilleran miogeocline: Geology, v. 20, p. 637-640, https://doi.org/10.1130/0091-7613(1992)020<0637:GDSITP>2.3.CO;2.

Hoffman, P.F, Kaufman, A.J., Halverson, G.P., and Schrag, D.P., 1998, A Neoproterozoic Snowball Earth: Science, v. 281, p. 1342-1346, https://doi.org/10.1126/science.281.5381.1342.

theffmann, K.-H., Condon, D.J., Bowring, S.A., and Crowley, J.L., 2004, U-Pb zircon date from the Neoproterozoic Ghaub Formation, Namibia: Constraints on Marinoan glaciation: Geology, v. 32, p. 817-820, https://doi.org/10.1130/G20519.1.

Holland, H.D., 2006, The oxygenation of the atmosphere and oceans: Philosophical Transaction of the Royal Society of London, ser. B, Biological Sciences, v. 361, p. 903-915, https://doi.org 10.1098/rstb.2006.1838.

Hollingsworth, J.S., 2005, The earliest occurrence of trilobites and brachiopods in the Cambrian of Laurentia: Palaeogeography, Palaeoclimatology, Palaeoecology, v. 220, p. 153-165, https://doi.org/10.1016/j.palaeo.2004.08.008.

Hunt, D.L., 1990, Trilobite Faunas and Biostratigraphy of the Lower Cambrian Wood Canyon Formation, Death Valley Region, California [Master's thesis]: Davis, California, University of California, $140 \mathrm{p}$.

Hunter, R.E., 1977, Basic types of stratification in small eolian dunes: Sedimentology, v. 24, no. 3 , p. 361-387, https://doi.org/10.1111/j.1365-3091.1977.tb00128.x.

Husson, J.M., Maloof, A.C., Schoene, B., Chen, C.Y., and Higgins, J.A., 2015, Stratigraphic expression of Earth's deepest $\delta^{13} \mathrm{C}$ excursion in the Wonoka Formation of South Australia: American Journal of Science, v. 315, p. 1-45, https://doi.org/10.2475/01.2015.01.

Kamb, W.B., 1959, Ice petrofabric observations from Blue Glacier, Washington, in relation to theory and experiment: Journal of Geophysical Research, v. 64, no. 11, p. 1891-1909, https: $/$ doi.org/10.1029/JZ064i011p01891.

Kaufman, A.J., Hayes, J.M., Knoll, A.H., and Germs, G.J.B., 1991, Isotopic compositions of carbonates and organic carbon from Upper Proterozoic successions in Namibia: Stratigraphic variation and the effects of diagenesis and metamorphism: Precambrian Research, v. 49, p. 301-327, https://doi.org/10.1016/0301-9268(91)90039-D. 
Kaufman, A.J., Corsetti, F.A., and Varni, M.A., 2007, The effect of rising atmospheric oxygen on carbon and sulfur isotope anomalies in the Neoproterozoic Johnnie Formation, Death Valley, USA: Chemical Geology, v. 237, p. 47-63, https://doi.org/10.1016/j.chemgeo.2006.06.023. Knauth, L.P., and Kennedy, M.J., 2009, The late Precambrian greening of the Earth: Nature, v. 460 no. 7256, p. 728-732, $10.1038 /$ nature 08213.

Knoll, A.H., and Carroll, S.B., 1999, Early animal evolution: Emerging views from comparative biology and geology: Science, v. 284, no. 5423, p. 2129-2137, https://doi.org/10.1126/science .284.5423.2129.

Knoll, A.H., Walter, M.R., Narbonne, G.M., and Christie-Blick, N., 2004, A new period for the geologic time scale: Science, v. 305, p. 621-622, https://doi.org/10.1126/science.1098803.

Knoll, A.H., Walter, M.R., Narbonne, G.M., and Christie-Blick, N., 2006, The Ediacaran Period: A new addition to the geologic time scale: Lethaia, v. 39, p. 13-30, https://doi.org/10.1080 100241160500409223 .

Kump, L.R., 2008, The rise of atmospheric oxygen: Nature, v. 451, p. 277-278, https://doi.org/10 $.1038 /$ nature 06587

Labotka, T.C., Albee, A.L., Lanphere, M.A., and McDowell, S.D., 1980, Stratigraphy, structure, and metamorphism in the central Panamint Mountains (Telescope Peak quadrangle), Death Valley area, California: Summary: Geological Society of America Bulletin, v. 91, p. 125-129, https://doi.org/10.1130/0016-7606(1980)91<125:SSAMIT>2.0.CO;2.

Larrieu, T.L., 1995, Basin analysis with a spreadsheet: Journal of Geological Education, v. 43 p. 107-113, https://doi.org/10.5408/0022-1368-43.2.107.

Le Guerroué, E., Allen, P.A., and Cozzi, A., 2006a, Chemostratigraphic and sedimentological framework of the largest negative carbon isotope excursion in Earth history: The Neoproterozoic Shuram Formation (Nafun Group, Oman): Precambrian Research, v. 146, p. 68 92, https://doi.org/10.1016/j.precamres.2006.01.007.

Le Guerroué, E., Allen, P.A., Cozzi, A., Etienne, J.L., and Fanning, M., 2006b, 50 Myr recovery from the largest negative $\delta^{13} \mathrm{C}$ excursion in the Ediacaran ocean: Terra Nova, v. 18, p. 147-153, https://doi.org/10.1111/j.1365-3121.2006.00674.

Lenton, T.M., Boyle, R.A., Poulton, S.W., Shields-Zhou, G.A., and Butterfield, N.J., 2014, Co-evolution of eukaryotes and ocean oxygenation in the Neoproterozoic Era: Nature Geoscience, v. 7, p. 257-265, https://doi.org/10.1038/ngeo2108.

Levy, M., and Christie-Blick, N., 1991, Tectonic subsidence of the early Paleozoic passive continental margin in eastern California and southern Nevada: Geological Society of America Bulletin v. 103, p. 1590-1606, https://doi.org/10.1130/0016-7606(1991)103<1590:TSOTEP>2.3.CO;2.

Li, Z.X., et al., 2008, Assembly, configuration, and break-up of Rodinia: A synthesis: Precambrian Research, v. 160, p. 179-210, https://doi.org/10.1016/j.precamres.2007.04.021.

Li, Z.X., Evans, D.A.D., and Halverson, G.P., 2013, Neoproterozoic glaciations in a revised global palaeogeography from the breakup of Rodinia to the assembly of Gondwanaland: Sedimentary Geology, v. 294, p. 219-232, https://doi.org/10.1016/j.sedgeo.2013.05.016.

Longwell, C.R., Pampeyan, E.H., Bowyer, B., and Roberts, R.J., 1965, Geology and Mineral Deposits of Clark County, Nevada: Nevada Bureau of Mines Bulletin 62, 218 p.

Loyd, S.J., Marenco, P.J., Hagadorn, J.W., Lyons, T.W., Kaufman, A.J., Sour-Tovar, F., and Corsetti, F.A., 2012, Sustained low marine sulfate concentrations from the Neoproterozoic to the Cambrian: Insights from carbonates of northwestern Mexico and eastern California: Earth and Planetary Science Letters, v. 339-340, p. 79-94, https://doi.org/10.1016/j.epsl.2012.05.032.

Loyd, S.J., Corsetti, F.A., Eagle, R.A., Hagadorn, J.W., Shen, Y., Zhang, X., Bonifacie, M., and Tripati, A.K., 2015, Evolution of Neoproterozoic Wonoka-Shuram anomaly-aged carbonates: Evidence from clumped isotope paleothermometry: Precambrian Research, v. 264, p. 179191, https://doi.org/10.1016/j.precamres.2015.04.010.

Macdonald, F.A., Jones, D.S., and Schrag, D.P., 2009, Stratigraphic and tectonic implications of a newly discovered glacial diamictite-cap carbonate couplet in southwestern Mongolia: Geology, v. 37, no. 2, p. 123-126, https://doi.org/10.1130/G24797A.1.

Macdonald, F.A., Strauss, J.V., Sperling, E.A., Halverson, G.P., Narbonne, G.M., Johnston, D.T. Kunzmann, M., Schrag, D.P., and Higgins, J.A., 2013, The stratigraphic relationship between the Shuram carbon isotope excursion, the oxygenation of Neoproterozoic oceans, and the first appearance of the Ediacaran biota and bilaterian trace fossils in northwestern Canada: Chemical Geology, v. 362, p. 250-272, https://doi.org/10.1016/j.chemgeo.2013.05.032.

Mahon, R.C., Dehler, C.M., Link, P.K., Karlstrom, K.E., and Gehrels, G.E., 2014, Geochronologic and stratigraphic constraints on the Mesoproterozoic and Neoproterozoic Pahrump Group Death Valley, California: A record of the assembly, stability, and breakup of Rodinia: Geological Society of America Bulletin, v. 126, no. 5/6, p. 652-664, https://doi.org/10.1130/B30956.1.
McFadden, K.A., Huang, J., Chu, X., Jiang, G., Kaufman, A.J., Zhou, C., Yuan, X., and Xiao, S 2008, Pulsed oxidation and biological evolution in the Ediacaran Doushantuo Formation Proceedings of the National Academy of Sciences of the United States of America, v. 105, no. 9, p. 3197-3202, https://doi.org/10.1073/pnas. 070833610

McKenzie, D., 1978, Some remarks on the development of sedimentary basins: Earth and Planetary Science Letters, v. 40, p. 25-32, https://doi.org/10.1016/0012-821X(78)90071-7,

cMenamin, M.A.S., 1996, Ediacaran biota from Sonora, Mexico: Proceedings of the Nationa Academy of Sciences of the United States of America, v. 93, p. 4990-4993, https://doi.org/10 1073/pnas.93.10.4990

Melezhik, V.A., Fallick, A.E., and Pokrovsky, B.G., 2005, Enigmatic nature of thick sedimentary carbonates depleted in ${ }^{13} \mathrm{C}$ beyond the canonical mantle value: The challenges to our understanding of the terrestrial carbon cycle: Precambrian Research, v. 137, p. 131-165, https://do .org/10.1016/j.precamres.2005.03.010

Melim, L.A., Swart, P.K., and Maliva, R.G., 1995, Meteoric-like fabrics forming in marine waters: Implications for the use of petrography to identify diagenetic environments: Geology v. 23 , no. 8 , p. $755-758$, https://doi.org/10.1130/0091-7613(1995)023<0755:MLFFIM $>2.3$ . $\mathrm{CO} ; 2$.

Melim, L.A., Swart, P.K., and Maliva, R.G., 2001, Meteoric and marine-burial diagenesis in the subsurface of the Great Bahama Bank, in Ginsburg, R.N., ed., Subsurface Geology of a Prograding Carbonate Platform Margin, Great Bahama Bank: Results of the Bahamas Drilling Project: Society of Economic Paleontologists and Mineralogists (Society for Sedimentary Geology) Special Publication 70, p. 137-161, https://doi.org/10.2110/pec.01.70.0137.

Minguez, D., and Kodama, K.P., 2017, Rock magnetic chronostratigraphy of the Shuram carbon isotope excursion: Wonoka Formation, Australia: Geology, v. 45, no. 6, p. 567-570, https:// doi.org/10.1130/G38572.1.

Minguez, D., Kodama, K.P., and Hillhouse, J.W., 2015, Paleomagnetic and cyclostratigraphic constraints on the synchroneity and duration of the Shuram carbon isotope excursion, Johnn Formation, Death Valley Region, CA: Precambrian Research, v. 266, p. 395-408, https://do .org/10.1016/j.precamres.2015.05.033.

Monger, J.W.H., and Price, R.A., 1979, Geodynamic evolution of the Canadian Cordillera-Progress and problems: Canadian Journal of Earth Sciences, v. 16, no. 3, p. 770-791, https://do .org/10.1139/e79-069.

Myrow, P.M., and Kaufman, A.J., 1999, A newly discovered cap carbonate above Varanger-age glacial deposits in Newfoundland, Canada: Journal of Sedimentary Research, v. 69, no. 3, p. 784-793, https://doi.org/10.2110/jsr.69.784.

arbonne, G.M., Xiao, S., Shields, G.A., and Gehling, J.G., 2012, The Ediacaran Period, in Gradstein, F.M., Ogg, J.G., Schmitz, M., and Ogg, G.M., eds., The Geologic Timescale 2012, Volume 1: Elsevier, p. 207-232, https://doi.org/10.1016/B978-0-444-59425-9.00018-4.

Nolan, T.B., 1924, Geology of the Northwest Portion of the Spring Mountains, Nevada [Ph.D. thesis]: New Haven, Connecticut, Yale University, $125 \mathrm{p}$.

Nolan, T.B., 1929, Notes on the stratigraphy and structure of the northwest portion of Spring Mountain, Nevada: American Journal of Science, ser. 5, v. 17, no. 101, p. 461-472.

Nursall, J.R., 1959, Oxygen as a prerequisite to the origin of the metazoa: Nature, v. 183, no. 4669 , p. 1170-1172, https://doi.org/10.1038/1831170b0.

ch, L.M., and Shields-Zhou, G.A., 2012, The Neoproterozoic oxygenation event: Environmenta perturbations and biogeochemical cycling: Earth-Science Reviews, v. 110, p. 26-57, https:// doi.org/10.1016/j.earscirev.2011.09.004.

Ogg, J.G., Ogg, G., and Gradstein, F.M., 2016, A Concise Geologic Timescale: 2016: Amsterdam, Netherlands, Elsevier, $240 \mathrm{p}$.

Osburn, M.R., Owens, J., Bergmann, K.D., Lyons, T.W., and Grotzinger, J.P., 2015, Dynamic changes in sulfate sulfur isotopes preceding the Ediacaran Shuram excursion: Geochimica et Cosmochimica Acta, v. 170, p. 204-224, https://doi.org/10.1016/j.gca.2015.07.039.

Palmer, A.R., 1981, Subdivision of the Sauk sequence, in Taylor, M.E., ed., Short Papers for the Second International Symposium on the Cambrian System: U.S. Geological Survey OpenFile Report 81-743, p. 160-163.

Palmer, A.R., and Halley, R.B., 1979, Physical Stratigraphy and Trilobite Biostratigraphy of the Carrara Formation (Lower and Middle Cambrian) in the Southern Great Basin: U.S. Geological Survey Professional Paper 1407, $131 \mathrm{p}$

Parsons, B., and Sclater, J.G., 1977, An analysis of the variation of ocean floor bathymetry and heat flow with age: Journal of Geophysical Research, v. 82, no. 5, p. 803-827, https://doi.org 10.1029/JB082i005p00803. 
Petterson, R., Prave, A.R., Wernicke, B.P., and Fallick, A.E., 2011, The Neoproterozoic Noonday Formation, Death Valley region, California: Geological Society of America Bulletin, v. 123, no. 7/8, p. 1539-1559, https://doi.org/10.1130/B30281.1.

Poole, F.G., Stewart, J.H., Palmer, A.R., Sandberg, C.A., Madrid, R.J., Ross, R.J., Jr., Hintze, L.F. Miller, M.M., and Wrucke, C.T., 1992, Latest Precambrian to latest Devonian time; development of a continental margin, in Burchfiel, B.C., Lipman, P.W., and Zoback, M.L., eds., The Cordilleran Orogen: Conterminous U.S.: Boulder, Colorado, Geological Society of America, The Geology of North America, v. G-3, p. 9-56, https://doi.org/10.1130/DNAG-GNA-G3.9.

Prave, A.R., Fallick, A.E., Thomas, C.W., and Graham, C.M., 2009, A composite C-isotope profile for the Neoproterozoic Dalradian Supergroup of Scotland and Ireland: Journal of the

Geological Society [London], v. 166, p. 845-857, https://doi.org/10.1144/0016-76492008-131.

Pu, J.P., Bowring, S.A., Ramezani, J., Myrow, P., Raub, T.D., Landing, E., Mills, A., Hodgin, E., and Macdonald, F.A., 2016, Dodging snowballs: Geochronology of the Gaskiers glaciation an the first appearance of Ediacaran biota: Geology, v. 44, no. 11, p. 955-958, https://doi.org/10 $.1130 / \mathrm{G} 38284.1$

Quinn, T., 1991, Meteoric diagenesis of Plio-Pleistocene limestones at Enewetak Atoll: Journal of Sedimentary Petrology, v. 61, no. 5, p. 681-703.

Sahoo, S.K., Planavsky, N.J., Kendall, B., Wang, X., Shi, X., Scott, C., Anbar, A.D., Lyons, T.W., and Jiang, G., 2012, Ocean oxygenation in the wake of the Marinoan glaciation: Nature, v. 489 p. 546-549, https://doi.org/10.1038/nature11445.

Saltzman, M.R., and Thomas, E., 2012, Carbon isotope stratigraphy, in Gradstein, F.M., Ogg, J.G. Schmitz, M., and Ogg, G.M., eds., The Geologic Timescale 2012, Volume 1: Amster
Netherlands, Elsevier, p. 207-232, https://doi.org/10.1016/B978-0-444-59425-9.00011-1.

Sawaki, Y., Ohno, T., Tahata, M., Komiya, T., Hirata, T., Maruyama, S., Windley, B.F., Han, J., Shu, $\mathrm{D}$. , and $\mathrm{Li}, \mathrm{Y}$., 2010, The Ediacaran radiogenic Sr isotope excursion in the Doushantuo Formation in the Three Gorges area, South China: Precambrian Research, v. 176, p. 46-64, https: doi.org/10.1016/j.precamres.2009.10.006

Sawyer, D.S., Swift, B.A., Sclater, J.G., and Toksöz, M.N., 1982, Extensional model for the subsidence of the northern United States Atlantic continental margin: Geology, v. 10, p. 134

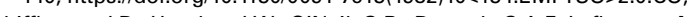

Schiffbauer, J.D., Huntley, J.W., O'Neil, G.R., Darroch, S.A.F., Laflamme, M., and Cai, Y., 2016, The latest Ediacaran wormworld fauna: Setting the ecological stage for the Cambrian explosion: GSA Today, v. 26, no. 11, p. 4-11, https://doi.org/10.1130/GSATG265A.

Schoenborn, W.A., and Fedo, C.M., 2011, Provenance and paleoweathering reconstruction of the Neoproterozoic Johnnie Formation, southeastern California: Chemical Geology, v. 285,

Schoenborn, W.A., Fedo, C.M., and Farmer, G.L., 2012, Provenance of the Neoproterozoic Johnnie Formation and Stirling Quartzite, southeastern California, determined by detrital zircon geochronology and Nd isotope geochemistry: Precambrian Research, v. 206-207, p. 182 199, https://doi.org/10.1016/j.precamres.2012.02.017

Sims, J.D., 2012, Earthquake-induced load casts, pseudonodules, ball-and-pillow structures, and convolute lamination: Additional deformation structures for paleoseismic studies, in Cox R.T., Tuttle, M.P., Boyd, O.S., and Locat, J., eds., Recent Advances in North American Paleoseismology and Neotectonics East of the Rockies: Geological Society of America Specia Paper 493, p. 191-201, https://doi.org/10.1130/2012.2493(09).

Smith, E.F., Nelson, L.L., Strange, M.A., Eyster, A.E., Rowland, S.M., Schrag, D.P., and Macdonald F.A., 2016, The end of the Ediacaran: Two new exceptionally preserved body fossil assemblages from Mount Dunfee, Nevada, USA: Geology, v. 44, no. 11, p. 911-914, https://doi.or /10.1130/G38157.1

Smith, E.F, Nelson, L.L., Tweedt, S.M., Zeng, H., and Workman, J.B., 2017, A cosmopolitan late Ediacaran biotic assemblage: New fossils from Nevada and Namibia support a globa biostratigraphic link: Proceedings of the Royal Society of London, ser. B, v. 284, no. 1858 p. 20170934, https://doi.org/10.1098/rspb.2017.0934

Steckler, M.S., and Watts, A.B., 1978, Subsidence of the Atlantic-type continental margin of New York: Earth and Planetary Science Letters, v. 41, p. 1-13, https://doi.org/10.1016/0012

Stewart, J.H., 1970, Upper Precambrian and Lower Cambrian Strata in the Southern Great Basin California and Nevada: U.S. Geological Survey Professional Paper 620, $206 \mathrm{p}$.
Stewart, J.H., 1972, Initial deposits in the Cordilleran geosyncline: Evidence of a late Precambrian (<850 m.y.) continental separation: Geological Society of America Bulletin, v. 83, p. 13451360, https://doi.org/10.1130/0016-7606(1972)83[1345:IDITCG]2.0.CO;2.

ewart, J.H., and Poole, F.G., 1974, Lower Paleozoic and uppermost Precambrian Cordilleran miogeocline, Great Basin, western United States, in Dickinson, W.R., ed., Tectonics and Sedimentation: Society of Economic Paleontologists and Mineralogists (SEPM) Special Publication 22, p. 28-57, https://doi.org/10.210/pec.74.22.0028.

tewart, J.H., and Suczek, C.A., 1977, Cambrian and latest Precambrian paleogeography and tectonics in the western United States, in Stewart, J.H., Stevens, C.H., and Fritsche, A.E., eds. Paleozoic Paleogeography of the Western United States: Los Angeles, California, Pacific Section, Society of Economic Palcontologists and Mineralogists (SEPM), p. 1-17.

(1) Uper Proterozoic and Cambrian Rocks in the Caborca Region, Sonora, Mexico-Physical Stratigraphy, Biostratigraphy, Paleocurrent Studies, and Regional Relations: U.S. Geological Survey Professiona Paper 1309, $36 \mathrm{p}$.

Summa, C.L., 1993, Sedimentologic, Stratigraphic, and Tectonic Controls of a Mixed Carbonate-Siliciclastic Succession: Neoproterozoic Johnnie Formation, Southeast California [Ph.D. thesis]: Cambridge, Massachusetts, Massachusetts Institute of Technology, $331 \mathrm{p}$.

Wart, P.K., and Kennedy, M.J., 2012, Does the global stratigraphic reproducibility of $\delta^{13} \mathrm{C}$ in Neoproterozoic carbonates require a marine origin? A Pliocene-Pleistocene comparison: Geo ogy, v. 40, no. 1, p. 87-90, https://doi.org/10.1130/G32538.1.

Thata, M., Ueno, Y., Ishikawa, T., Sawaki, Y., Murakami, K., Han, J., Shu, D., Li, Y., Guo, J., Yoshida, N., and Komiya, T., 2013, Carbon and oxygen isotope chemostratigraphies of the Yangtze platform, South China. Decoding temperature and environmental changes through the Ediacaran: Gondwana Research, v. 23, p. 333-353, https://doi.org/10.1016/.gr.2012.04.005

rower, E.J., and Grotzinger, J.P., 2010, Sedimentology, diagenesis, and stratigraphic occurrence of giant ooids in the Ediacaran Rainstorm Member, Johnnie Formation, Death Valley region, California: Precambrian Research, v. 180, p. 113-124, https://doi.org/10.1016/j.precamres 2010.03.007.

J.S. Geological Survey, 1968, Mt. Schader 7.5 Minute Quadrangle, Nye County, Nevada: U.S. Geological Survey, scale 1:24,000

erdel, C., Wernicke, B.P., and Bowring, S.A., 2011, The Shuram and subsequent Ediacaran carbon isotope excursions from southwest Laurentia, and implications for environmental stability during the metazoan radiation: Geological Society of America Bulletin, v. 123, no. 7/8, p. 1539-1559, https://doi.org/10.1130/B30369.

Walker, J.D., Geissman, J.W., Bowring, S.A., and Babcock, L.E., 2013, The Geological Society of America Geologic Time Scale: Geological Society of America Bulletin, v. 125, no. 3/4 p. 259-272, https://doi.org/10.1130/B30712.1.

Wright, L.A., and Troxel, B.W., 1966, Strata of late Precambrian-Cambrian age, Death Valley region, California-Nevada: American Association of Petroleum Geologists Bulletin, v. 50, no. 5 p. 846-857.

Wright, L.A., and Troxel, B.W., 1984, Geology of the North 1/2 Confidence Hills 15' Quadrangle, Inyo County, California: California Division of Mines and Geology Map Sheet 34, scale 1:24,000, 1 sheet, 31 p. text.

Xiao, S., Bao, H., Wang, H., Kaufman, A.J., Zhou, C., Li, G., Yuan, X., and Ling, H., 2004, The Neoproterozoic Quruqtagh Group in eastern Chinese Tianshan: Evidence for a post-Marinoan glaciation: Precambrian Research, v. 130, p. 1-26, https://doi.org/10.1016/j.precamres.2003.10.013 Xiao, S., Narbonne, G.M., Zhou, C., Laflamme, M., Grazhdankin, D.V., Moczydlowska-Vidal, M. and Cui, H., 2016, Towards an Ediacaran time scale: Problems, protocols, and prospects: Episodes, v. 39, no. 4, p. 540-555, https://doi.org/10.18814/epiiugs/2016/v39i4/103886

Yonkee, W.A., Dehler, C.D., Link, P.K., Balgord, E.A., Keeley, J.A., Hayes, D.S., Wells, M.L., Fanning, C.M., and Johnston, S.M., 2014, Tectono-stratigraphic framework of Neoproterozoic to Cambrian strata, west-central U.S.: Protracted rifting, glaciation, and evolution of the North American Cordilleran margin: Earth-Science Reviews, v. 136, p. 59-95, https://doi.org/10 .1016/j.earscirev.2014.05.004

Zhou, C., Xie, G., McFadden, K., Xiao, S., and Yuan, X., 2007, The diversification and extinction of Doushantuo-Pertatataka acritarchs in South China: Causes and biostratigraphic significance: Geological Journal, v. 42, p. 229-262, https://doi.org/10.1002/gj.1062. 